


\section{The potential of new conversion technologies for adding value to Malaysian oil palm residues and increasing sustainability}

Authors: J.W. van Groenestijn and I. Vural Gürsel

Institute: Wageningen Food \& Biobased Research

This research project has been carried out by Wageningen Food \& Biobased Research, in the context of Showcasing potential of Dutch solutions for the usage and recyling of palm oil residues in Malaysia (project number 6220093200).

Wageningen Food \& Biobased Research

Wageningen, May 2019

Public

Report 1989

ISBN 978-94-6395-181-4 
Version: final

Reviewer: W. Elbersen

Approved by: J. Jetten

Sponsor: RVO

This report can be downloaded for free at https://doi.org/10.18174/504613/ or at www.wur.eu/wfbr (under publications).

(C) 2019 Wageningen Food \& Biobased Research, institute within the legal entity Stichting Wageningen Research.

The client is entitled to disclose this report in full and make it available to third parties for review. Without prior written consent from Wageningen Food \& Biobased Research, it is not permitted to:

a. partially publish this report created by Wageningen Food \& Biobased Research or partially disclose it in any other way;

b. (let a third party) use this report created by Wageningen Food \& Biobased Research or the name of the report or Wageningen Food \& Biobased Research in whole or in part for the purposes of making claims, conducting legal procedures, for (negative) publicity, and for recruitment in a more general sense;

c. use the name of Wageningen Food \& Biobased Research in a different sense than as the author of this report.

PO box 17, 6700 AA Wageningen, The Netherlands, T + 31 (0)317 4800 84, E info.wfbr@wur.nl, www.wur.eu/wfbr. Wageningen Food \& Biobased Research is part of Wageningen University \& Research.

All rights reserved. No part of this publication may be reproduced, stored in a retrieval system of any nature, or transmitted, in any form or by any means, electronic, mechanical, photocopying, recording or otherwise, without the prior permission of the publisher. RVO has this permission. The publisher does not accept any liability for inaccuracies in this report. 


\section{Contents}

Preface $\quad 5$

$\begin{array}{lc}\text { Summary } & 6\end{array}$

$\begin{array}{llr}1 & \text { Introduction } & 9\end{array}$

2 Methods $r$

2.1 Preamble $\quad 10$

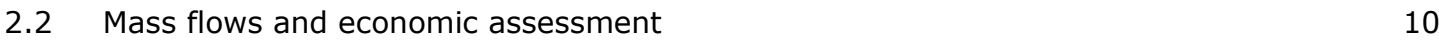

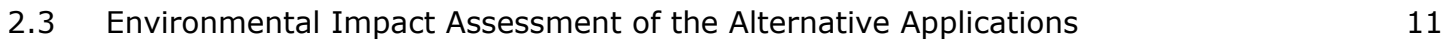

2.3.1 Greenhouse Gas Accounting Methodology 11

2.3.2 BioGrace Tool 12

2.3.3 Method in relation to the goal 12

2.3.4 Scope, System Boundaries and Functional Unit $\quad 12$

$3 \quad$ Mass and energy flows of base case and five alternatives 13

3.1 The base case: business as usual 13

3.2 Alternative 1: POME conversion into biogas and use of biogas in existing CHP 14

3.3 Alternative 2: POME conversion into biogas and use of biogas as transportation fuel 16

3.4 Alternative 3: EFB conversion into black pellets (by TORWASH®) 18

3.5 Alternative 4: EFB washing and feeding in the existing $\mathrm{CHP} \quad 20$

3.6 Alternative 5: combination of using biogas from POME and washed EFB in the existing CHP

$\begin{array}{lll}4.1 & \text { Preamble } & 24\end{array}$

4.2 Alternative 1: POME conversion into biogas and use of biogas in an existing CHP 24

4.3 Alternative 2: POME conversion into biogas and use of biogas as transportation fuel 25

4.4 Alternative 3: EFB conversion into black pellets (by TORWASH®) 26

4.5 Alternative 4: EFB washing and feeding in the existing $\mathrm{CHP} \quad 27$

4.6 Alternative 5: combination of using biogas from POME and washed EFB in the existing CHP

$5 \quad$ Environmental impact assessment $\quad 30$

$\begin{array}{lll}5.1 & \text { Pathways } & 30\end{array}$

$\begin{array}{lll}5.2 & \text { Life Cycle Inventory } & 30\end{array}$

5.2.1 Process flow diagrams $\quad 30$

$\begin{array}{lll}5.2 .2 & \text { Data sources } & 32\end{array}$

5.2.3 Inventory Tables

5.2.4 Additional processes $\quad 34$

5.3 Impact Assessment Results $\quad 35$

$\begin{array}{lll}5.4 & \text { Interpretation of the results } & 42\end{array}$

5.5 Case Studies $\quad 43$

5.5.1 EFB CHP emissions - approximated with Palm shells and fibres 43

5.5.2 Interpretation $\quad 44$

5.6 Credit for the excess palm shells and fibres 45

5.7 Alternative accounting for the additional co-products through system expansion $\quad 47$

$\begin{array}{lll}5.8 & \text { Methane emission from EFB heaps in the field } & 48\end{array}$ 
1.1 The base case: business as usual

1.2 Alternative 1: POME conversion into biogas and use of biogas in an existing CHP

1.3 Alternative 2: POME conversion into biogas and use of biogas as transportation fuel

1.4 Alternative 3: EFB conversion into black pellets (by TORWASH®)

1.5 Alternative 4: EFB washing and feeding in the existing $\mathrm{CHP}$

1.6 Alternative 5: combination of using biogas from POME and washed EFB in the existing CHP75 


\section{Preface}

This report is the result of a study financed by RVO under RVO project number K2K16C1302. Kees Kwant and José Muisers (RVO) are acknowledged for their support and valuable feed-back. The companies in the Palmares team are thanked for supplying information on the technologies. Rob van As (Paques) on POME (palm oil mill effluent) treatment and biogas production, Harmen Dekker (DMT) on biogas upgrading and compression, Levien de Legé (ECN part of TNO) on TORWASH $®$ and torrefaction of EFB (empty fruit bunch) and Thomas Chopin (Blackwood Technology) on torrefaction. The authors are grateful to the colleagues of Wageningen Food \& Biobased Research who assisted with data and information: Koen Meesters, Wolter Elbersen and Juliën Voogt. 


\section{Summary}

The palm oil industry is important for Malaysia. In the oil palm plantations in Malaysia water and fertilizers are used to grow the palms. Fresh fruit bunches (FFB) are harvested at a few week intervals from the palms. The FFB is processed in local mills fruits and empty fruit bunch. The empty fruit bunches are generally not used in the mail - sometimes compost is made but generally EFB is used as mulched in nearby plantations where the added value is limited. The palm fruits are processed and the mesocarp fibre is separated from the kernel. Crude palm oil is pressed from the mesocarp. This CPO is the main product of the mill. The mesocarp fibre is mostly used as fuel in a combined heat and power (CHP) unit in which steam for the mill is produced and often also electricity, both used in the mill. A different grade (and lower amounts) of oil is pressed from the kernel. The kernel is separated in shells and kernel meal. The meal is generally sold as cattle feed part of the shells are used in the CHP unit. The palm oil mill effluent (POME) is treated in lagoons and if these lagoons are not covered the methane produced in these lagoons is emitted to the atmosphere. The water is discharged when the BOD (Biological Oxygen Demand) level is sufficiently reduced. Sometimes as fertilizer in nearby plantations but often also into local surface water. Fronds are left in the plantation. After decay, these fronds serve as a slow release fertilizer to improve soil fertilityminerals are returned to the soil ( $N, P$ and $\mathrm{K}$ ). When the plantation get less productive after some 25 years the palms are cut and the trunks are generally chipped and let in the field as mulch.

It has been suggested that the sustainability and circularity of this industry can be improved by using biomass conversion technologies to add value to the biomass produced. New technologies include efficient anaerobic digestion of palm oil mill effluent and the utilization of the biogas in a CHP unit or as transportation fuel. Empty fruit bunch can be washed and converted into black pellets by torrefaction such as the TORWASH $®$ technology assessed here. These pellets can be sold as a renewable fuel replacing coal. Alternatively, the empty fruit bunches can be washed, pressed and used in a CHP (combined heat and power) unit. By using biogas or empty fruit bunch in the CHP unit, mesocarp and palm kernel shells can be saved and sold as renewable / high value fuels, or used for other applications.

In this study we compared different alternative residue treatment and application options and assessed the overall sustainability effect on CPO. The idea being that using residues for alternative applications will reduce the impact that will attributed to palm oil because part of the impact is attributed to the residue which has a useful application.

A base case (business as usual) was compared with five alternatives and assessed on greenhouse gas emission, recycling of nutrients $(\mathrm{N}, \mathrm{P}$ and $\mathrm{K}$ ) and economic feasibility. The alternatives studied were:

1. Palm oil mill effluent (POME) digestion and use of biogas in an existing CHP replacing oil palm mesocarp fibre (MF) or palm kernel shells (PKS) currently used as solid fuel and reducing methane emissions

2. POME digestion (same as alternative 1) and use of biogas by upgrading to bio natural gas and compressing it to bio-CNG for use in cars and trucks and reducing methane emissions

3. Pretreatment (torrefaction, Torwash) of empty fruit bunch (EFB) and production of black pellets that can be sold as renewable fuel

4. Pretreatment and direct burning of EFB in an existing CHP replacing mesocarp fibre that may then be sold as solid fuel

5. Combinations of alternatives 1 and 4 .

As seen in the table below, all alternatives seem economically feasible. Alternatives 3, 4 and 5 are economically favourable. The benefits from sales of EFB black pellets, mesocarp fibre and palm kernel shells are much greater that the costs involved to realize the new operation. 
Table A: Summary of changes in mass flows compared to the base case, costs and benefits of 5 alternative operations.

\begin{tabular}{|c|c|c|c|c|c|}
\hline & \multicolumn{5}{|l|}{ Alternatives } \\
\hline & 1 & 2 & 3 & 4 & 5 \\
\hline & $\begin{array}{l}\text { POME biogas } \\
\text { CHP }\end{array}$ & $\begin{array}{l}\text { POME } \\
\text { biomethane }\end{array}$ & EFB black pellets & EFB CHP & Combi $1+4$ \\
\hline $\begin{array}{l}\text { Methane emission } \\
\text { (kg/ton FFB DM) }\end{array}$ & 0 & 0 & 6.9 & 6.9 & 0 \\
\hline $\begin{array}{l}\text { Methane utilization } \\
\text { (kg/ton FFB DM) }\end{array}$ & 6.7 & 5.7 & 0 & 0 & 6.7 \\
\hline $\begin{array}{l}\text { Fertilizers saved } \\
\text { (kg/ton FFB DM) }\end{array}$ & & & & & \\
\hline $\mathrm{N}$ & 1 & 1 & 1.19 & 0.14 & 1,14 \\
\hline$P$ & 0.15 & 0.15 & 0.21 & 0.12 & 0.27 \\
\hline K & 2.85 & 2.85 & 3.44 & 3.22 & 6.07 \\
\hline $\begin{array}{l}\text { EFB black pellets } \\
\text { sold (MJ/ton FFB } \\
\text { DM) }\end{array}$ & 0 & 0 & 4.57 & 0 & 0 \\
\hline $\begin{array}{l}\text { Additional } \\
\text { mesocarp fibres } \\
\text { and PKS sold } \\
\text { (MJ/ton FFB DM) }\end{array}$ & 0.37 & 0 & 0 & 4.84 & 5.23 \\
\hline $\begin{array}{l}\text { Costs of the new } \\
\text { operation ( } € / \text { ton } \\
\text { FFB DM) }\end{array}$ & 1.73 & 2.36 & $3.25-6.50$ & 1.51 & 3.24 \\
\hline $\begin{array}{l}\text { Benefits of the } \\
\text { new operation } \\
(€ / \text { ton FFB DM) }\end{array}$ & 4.26 & 3.79 & $23.50-27.07$ & 17.71 & 22.58 \\
\hline $\begin{array}{l}\text { Benefits minus } \\
\text { costs ( } € / \text { ton FFB } \\
\text { DM) }\end{array}$ & 2.53 & 1.43 & \pm 20 & 16.2 & 19.34 \\
\hline $\begin{array}{l}\text { Return of } \\
\text { Investment } \\
\text { (payback time in } \\
\text { years) }\end{array}$ & 2.6 & 5.8 & 1.1 & 0.23 & 0.64 \\
\hline
\end{tabular}

Since palm oil costs about $€ 540$ /ton and 0.34 ton palm oil is produced per ton FFB dry matter, the palm oil value per ton FFB dry matter is $€ 183$. As can be seen in the table above the savings can be more than $10 \%$ of the palm oil value.

The dry matter content of FFB can be between $40 \%$ and $60 \%$, therefore, the savings can be near $€ 8$ to $€$ 12 per ton (wet) FFB.

Substantial reduction of greenhouse gas emissions of the palm oil mill are possible in all five alternatives, due to the use of methane as a fuel, to the sales of residues as fuel and to recycling of nutrients. $50 \%$ reduction is possible using Innovative technologies. The largest effect is prevention of emission of greenhouse gases from lagoons. MF and PKS can be used and sold as fuel to replace coal, which can reduce GHG emissions, which could have a value on the carbon credit market (yield carbon credits) but also additional emissions such as $\mathrm{N}_{2} \mathrm{O}$ as MF and PKS contain nitrogen. 
The allocated GHG emissions decrease from $48.27 \mathrm{~g} \mathrm{CO}_{2}$,eq/MJ PO in the base case to 24 to $42 \mathrm{~g}$ $\mathrm{CO}_{2}$, eq/MJ PO in the alternatives. Expressed per ton palm oil: from 1.9 ton $\mathrm{CO}_{2}$,eq/ton PO in the base case to 0.96 to $1.7 \mathrm{~g} \mathrm{CO}_{2}$,eq/ton $\mathrm{PO}$ in the alternatives.

The label 'allocated emissions' means that the emissions are allocated (distributed, divided) over all products that are sold to parties outside the oil mill. If more products exist than only palm oil, the (allocated) emission caused by palm oil production will be lower than the case in which no allocation is used. In the latter all emission will be attributed to palm oil production.

Table B: Total non-allocated and allocated credits for the use of excess palm kernel shells and mesocarp fibres.

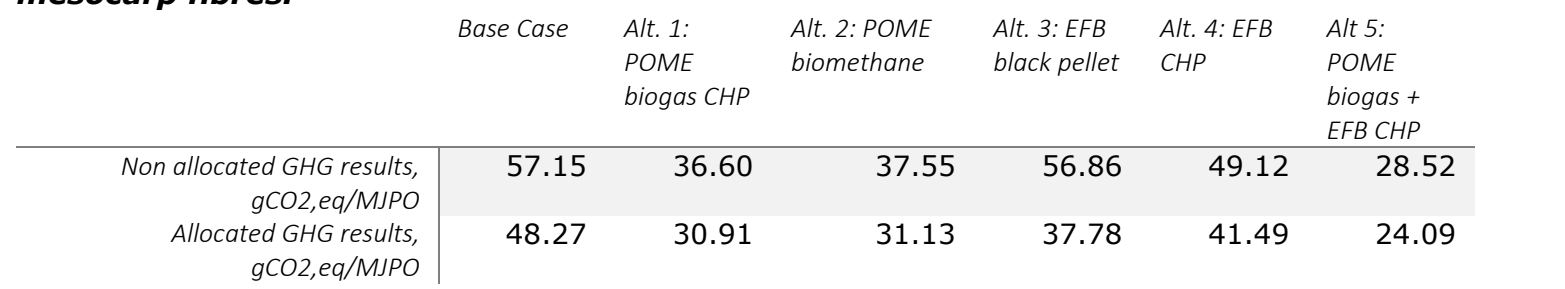

\begin{tabular}{|c|c|c|c|c|c|c|}
\hline & Base Case & $\begin{array}{l}\text { Alt. 1: } \\
\text { POME } \\
\text { biogas CHP }\end{array}$ & $\begin{array}{l}\text { Alt. 2: POME } \\
\text { biomethane }\end{array}$ & $\begin{array}{l}\text { Alt. 3: } E F B \\
\text { black pellet }\end{array}$ & $\begin{array}{l}\text { Alt. 4: EFB } \\
\text { CHP }\end{array}$ & $\begin{array}{l}\text { Alt 5: } \\
\text { POME } \\
\text { biogas + } \\
\text { EFB CHP }\end{array}$ \\
\hline $\begin{array}{r}\text { Non allocated GHG results, } \\
\text { kgCO2,eq/ton FFB DM }\end{array}$ & 718.9 & 460.4 & 472.4 & 715.3 & 617.9 & 358.7 \\
\hline $\begin{array}{l}\text { Allocated GHG results, } \\
\mathrm{kgCO}, \text { eq/ton FFB DM }\end{array}$ & 607.3 & 388.9 & 391.6 & 475.3 & 521.9 & 303.0 \\
\hline
\end{tabular}

In the alternatives, fuels such as black pellets and bio-CNG are produced. In some alternatives larger amounts of kernel and fibre are produced which can be used as a fuel as well. These biofuels can be used to replace fossil energy sources and carbon credits (avoiding GHG emissions) can be deserved.

- In alternative 1 additional shells and fibres are produced, which can be used in power plants. The credits are estimated $0.19 \mathrm{~g} \mathrm{CO}_{2}$,eq per $\mathrm{MJ}$ palm oil.

- In alternative 2 bio-CNG is produced, which can be used to replace diesel in trucks. The credits are estimated $1.5 \mathrm{~g} \mathrm{CO}_{2}$,eq per $\mathrm{MJ}$ palm oil.

- In alternative 3 black pellets are produced, which can be used in power plants. The credits are estimated $27.7 \mathrm{~g} \mathrm{CO}_{2}$,eq per MJ palm oil.

- In alternative 4 additional shells and fibres are produced, which can be used in power plants. The credits are estimated $1.77 \mathrm{~g} \mathrm{CO}_{2}$,eq per MJ palm oil (see Table 30 ).

- In alternative 5 additional shells and fibres are produced, which can be used in power plants. The credits are estimated $1.97 \mathrm{~g} \mathrm{CO}_{2}$,eq per MJ palm oil (see Table 30).

These numbers cannot be added to the allocated results in the table above as this will be double counting.

The storage of EFB deserves attention. Putrefaction should be avoided. In a worst case the emission of methane by spontaneously digesting EFB heaps may represent $1050 \mathrm{~kg} \mathrm{CO}$, eq per ton FFB dry matter, which is $83 \mathrm{~g} \mathrm{CO}_{2}$, eq per $\mathrm{MJ} \mathrm{PO}$. 


\section{Introduction}

The palm industry is an important economic sector in Malaysia. Huge areas are used as plantation to grow oil palms. The total area is estimated at about 4,6 Mha (Garcia-Nunez, 2016a), which yield more than 57 Mton fresh fruit bunch DM (FFB) annually (Visser et al., 2018). The main products are the various types of oil pressed from the fruits, of which crude palm oil from the mesocarp is the most important. In addition, solid and liquid residues are produced, which contain energy and nutrients. These large amounts of residues currently have few applications or applications with low added value. Utilization and recycling of these residues will help the sustainability and circularity of the oil palm mill operation which yield a reduction in the emission of greenhouse gases. Moreover, residue utilization can by profitable.

In the first part of 2018 research has been conducted in order to make clear that techniques and knowledge of the Dutch sector are very well applicable in the Malaysian context. The research, which was an assignment given by RVO to TNO, showed very promising very results. In this report 'Creating green value from palm residues in Malaysia' several alternatives applications have been described (Visser et al., 2018).

During a mission and seminar in Malaysia of representatives of RVO and the Dutch in the winter of 2018 the research results were discussed and the first steps were taken towards a fruitful cooperation. Representatives of the Malaysian government and private palm oil sector are very interested in the knowledge and techniques of the Dutch. However, an expert of RVO and the representatives from the Malaysian government and private sector agreed that, in addition to the research that has already been conducted, an assessment to describe the economic and environmental perspectives of these alternative applications in more detail is needed. When well-presented the assessment will be convincing to Malaysian palm mill owners of the benefits of cooperation of the (entire) Dutch sector.

This assessment is subject of the current report. It establishes the economic and environmental impacts of introducing these technologies and to assess how the use of residues for added value can reduce the environmental impact of the main product if part of the impact is allocated to the residue product.

The study is an assignment of RVO to Wageningen Food \& Biobased Research (RVO number K2K16C1302). WFBR has conducted the research independently. RVO is the user of the information.

The report shows the added value of the techniques and knowledge the Dutch sector has to offer. This report provides an overview of the alternatives to a base case (business as usual). The report includes fertilizer needs, greenhouse gas emissions, estimated costs and revenues. In addition, it includes mass and energy balances as well as a list of assumptions.

In this study the following alternatives were evaluated:

- Business as usual

- $\quad$ Palm oil mill effluent (POME) digestion and use of biogas in combined heat and power unit (CHP) replacing oil palm mesocarp fibre or palm kernel shells currently used as solid fuel and reducing methane emissions

- POME digestion and use of biomethane as bio-CNG in cars and trucks (LNG) and reducing methane emissions

- $\quad$ Pretreatment (torrefaction, Torwash) of empty fruit bunch (EFB)

- Pretreatment and direct burning of EFB in CHP replacing mesocarp fibre that may be sold as solid fuel

- And combinations of these alternatives, optimizing the use of all residues from the mill 


\section{Methods}

\subsection{Preamble}

The base of the current study is an earlier study (K2K-16C1301) including the report "Creating green value from palm residues in Malaysia, a Palmares project" (Visser et al., 2018) and the data-bases created in this earlier study. These data-bases comprised the mass flows in a palm oil mill, including all organic residues, the energy flows and the nutrient flows. In study $\mathrm{K} 2 \mathrm{~K}-16 \mathrm{C} 1301$ a list of alternatives was created on the utilization of POME, EFB, mesocarp fibres and palm kernel shells. After agreement with RVO four alternatives were selected from this list and a fifth alternative was created as a combination of two other alternatives.

\subsection{Mass flows and economic assessment}

New mass flow and energy flow data were generated for the five alternatives. The new values were based on calculations and estimations. The data (estimations) given by companies were used and added to data from literature.

The following assumptions were made:

- All assumption regarding mass and energy flow of the base case and HHV of materials involved made by Visser et al. (2018).

- The trunks and fronds are left in the fields and are degraded and mineralized over time. This way N, P and $\mathrm{K}$ in the trunks and fronds are eventually reused by the palm trees.

- An average palm mill has 6500 operation hours per year (information from DMT).

- $\quad$ FFB contains $60 \%$ dry matter.

- HHV of methane is $55.4 \mathrm{MJ} / \mathrm{kg}$.

- In this particular case an oil mill with POME containing 75,000 mg COD/L is assumed (information from Paques). The COD concentration in Malaysian oil mill can fluctuate. Year round sampling at three Malaysian oil mills yielded an average of $79,000 \mathrm{mg}$ COD/L with a standards deviation of $10,803 \mathrm{mg}$ COD/L (Poh et al., 2010).

- $\quad 6.85 \mathrm{~kg}$ methane is emitted to the atmosphere from open lagoons per $50 \mathrm{~kg}$ POME DM.

- In anaerobic digesters, after removal of floating matter/oil, $66 \%$ of the energy of POME can be converted into methane-energy.

- $\quad$ After anaerobic treatment of POME and aerobic post-treatment the effluent contains $20 \mathrm{mg} \mathrm{BOD/L}$ and can be used for irrigation (information from Paques).

- $\quad 2.5 \%$ of the methane produced in POME digesters is used to generate energy for aeration in the posttreatment (information from Paques)

- Unpurified biogas contains $59.5 \%(\mathrm{v} / \mathrm{v}$ ) methane (information from DMT).

- $\quad$ By TORWASH® $83 \% \mathrm{~N}, 86 \% \mathrm{P}$ and $96 \% \mathrm{~K}$ is removed from the solid fraction of EFB (information from ECN part of TNO).

- $\quad$ Black pellets produced by TORWASH® have $10 \%$ higher energy content per kg DM (information from ECN part of TNO).

- $\quad$ TORWASH $®$ needs 0.75 ton fresh washing water (next to POME as washing water) per ton EFB DM (information from ECN part of TNO).

- In counter-current washing of EFB, followed by pressing a dry matter content of $50 \%$ is created (information from Koen Meesters, WFBR, based on experimental results).

- Two ton fresh water is required in such EFB washing per ton EFB DM (information from Koen Meesters, WFBR, based on experimental results).

- In such washing $10 \% \mathrm{COD}, 10 \% \mathrm{DM}, 10 \%$ energy content, $10 \% \mathrm{~N}, 50 \% \mathrm{P}$ and $90 \% \mathrm{~K}$ is washed out (information from Koen Meesters, WFBR, based on experimental results and estimations).

- Annual depreciation and interest: $12 \%$ of the CAPEX (based on depreciation in 10 years and $2 \%$ interest). 
- Annual maintenance: $4 \%$ of CAPEX (based of on information from DMT); Insurance: $2 \%$ of CAPEX: together $6 \%$ of the CAPEX.

- Efficiencies of existing palm oil mill CHP on different fuels can be found in Table 1 in section 3.6. The estimations are obtained using SuperPro design tool in combination with Garcia-Nunez et al.(2016b),

- The electric efficiency of dedicated biogas CHP amounts 40\% (information from DMT).

- CAPEX anaerobic digesters and aerobic post-treatment amounts M€ 5.5 to treat POME from a typical oil mill that processes 60 ton FFB per hour (Uslu et al., 2018 after own calculations; see section 4.2).

- Cost for biogas upgrading and compression (method DMT): $€ 0.11 / \mathrm{kg}$ methane (information from DMT).

- $\quad$ CAPEX TORWASH® equipment between M€ 4 - M€ 8 to process EFB from a typical oil mill that processes 60 ton FFB per hour (information from ECN part of TNO).

- $€ 6.28$ required per ton EFB DM for counter-current washing (Meesters \& Elbersen, 2008).

- Value mesocarp fibres and palm kernel shells at the gate of the oil mill: $€ 70 /$ ton DM (www.palmkernelshell.id/palm-kernel-shell-price/).

- Value EFB black pellets at the gate of the oil mill: $€$ 108-126/ton DM (information from Blackwood Technology).

- Consumer price compressed methane for trucks and cars: $€ 0.37 / \mathrm{kg}$ methane (information from DMT).

- $\quad$ Price N fertilizer: $€ 400 /$ ton N (Voogt et al., 2018).

- Price P fertilizer: $€ 687 /$ ton P (Voogt et al., 2018).

- $\quad$ Price $K$ fertilizer: $€ 431$ /ton K (Voogt et al., 2018).

These assumptions are discussed in the next sections in which the source of the data is indicated and in which it is shown how data were calculated.

Cost indications connected to the processes were requested with relevant technology providers (in Palmares) and combined with literature data and own calculations and estimations. In the next chapters the base case and the five alternatives are described. The table and graphs with mass and energy flows can be found in Annex 1.

\subsection{Environmental Impact Assessment of the Alternative Applications}

\subsubsection{Greenhouse Gas Accounting Methodology}

For the greenhouse gas accounting, methodology laid down in the EU Renewable Energy Directive (RED) was used (Directive 2018/2001). Specific points that are indicated within this directive are copied below to draw attention on significant points that have a large impact on the final result of the life cycle analysis conducted:

- "Capture of $\mathrm{CO}_{2}$ in the cultivation of raw materials shall be excluded."

- "Where a fuel production process produces, in combination, the fuel for which emissions are being calculated and one or more other products (co-products), greenhouse gas emissions shall be divided between the fuel or its intermediate product and the co-products in proportion to their energy content (determined by lower heating value in the case of co-products other than electricity and heat)."

- "Where a cogeneration unit - providing heat and/or electricity to a fuel production process for which emissions are being calculated - produces excess electricity and/or excess useful heat, the greenhouse gas emissions shall be divided between the electricity and the useful heat according to the temperature of the heat (which reflects the usefulness (utility) of the heat)." - allocation based on exergy instead of energy.

- $\quad$ "No emissions shall be allocated to wastes and residues. Wastes and residues shall be considered to have zero life-cycle greenhouse gas emissions up to the process of collection of those materials."

- "Emissions of $\mathrm{CO}_{2}$ from fuel in use, shall be taken to be zero for biomass fuels. Emissions of non- $\mathrm{CO}_{2}$ greenhouse gases $\left(\mathrm{CH}_{4}\right.$ and $\left.\mathrm{N}_{2} \mathrm{O}\right)$ from the fuel in use shall be included." 


\subsubsection{BioGrace Tool}

For the estimations the BioGrace-II tool was utilised. This tool provides transparent GHG calculations for electricity, heating and cooling from biomass. It is based on the methodology laid down in older EC documents (State of play on the sustainability of solid and gaseous biomass used for electricity, heating and cooling in the EU [SWD(2014) 259]; Report on sustainability requirements for the use of solid and gaseous biomass sources in electricity, heating and cooling [COM/2010/11]), but still consistent with the methodology provided in recent RED recast published in 2018. The tool contains 27 pathways including solid and gaseous biomass for energy use and bioliquid pathways for the production of vegetal oil. For the purpose of this project additional pathways needed to be created with the tool. This was done by copying an existing pathway and modifying it as necessary. The existing pathways that were copied in this assessment are "Pure plant oil from palm oil", "Biogas from biowaste" and "Biomethane from biowaste". They were modified according to the characteristics of the alternative processes considered in valorising the Malaysian palm oil industry residues and entering the corresponding input data.

\subsubsection{Method in relation to the goal}

Several alternative applications of Malaysian palm oil industry residues are considered and analysed within this project. The purpose of this part of the project is to evaluate the environmental and more specifically the greenhouse gas emission impacts of these options in comparison to the base case (business as usual). It is assessed how the utilization of residues can reduce the environmental impact of the main product of palm oil. The GHG accounting methodology laid down by the European Commission is followed.

\subsubsection{Scope, System Boundaries and Functional Unit}

The geographical scope is Malaysia. Temporal scope is current production (2018-2019) with relevant technological developments foreseen for the short-time future (5 years).

A cradle to gate approach is taken. The specific stages considered are cultivation of fresh fruit bunch (FFB), transportation of FFB and extraction of oil. This includes the emissions from the production and use of the energy within the processes. The different valorisation processes for the residues is considered within the system boundaries. The final product considered is unrefined palm oil. This is because the downstream processes that include refining, transportation of pure vegetable oil and final use (end of life) stages are identical for all the cases considered and therefore excluded from the comparative assessment carried out. Since same amount of FFB production is considered for all the cases, direct land use change calculation is excluded from the assessment. However, it should be noted that if rather than a comparative assessment, an absolute GHG impact assessment was to be carried out, it would have been necessary to carry out this calculation, as land use change can have substantial impact in the overall GHG impact. It should be further noted that values for indirect land use change are not included for the same reasons and also since there is still a lot of controversy regarding its quantification.

The functional unit is production of $1 \mathrm{MJ}$ unrefined palm oil. 


\section{Mass and energy flows of base case and five alternatives}

\subsection{The base case: business as usual}

In the average Malaysian oil plantation water and fertilizers are used to grow the palms. Trunks and fronds are left in the plantation. After decay of these trunks and fronds minerals are returned to the soil ( $N, P$ and $\mathrm{K})$. Fresh fruit bunches are harvested and separated into fruits and empty fruit bunch. The empty fruit bunches are often left as mulch in nearby plantations. The fruits are processed and the mesocarp is separated from the kernel. Oil is pressed from the mesocarp. This oil is the main product of the mill. The mesocarp fibres are partly used as fuel in a combined heat and power (CHP) unit in which electricity and heat are produced, both used in the mill. A different grade (and lower amounts) of oil is pressed from the kernel. The kernel is separated in shells and kernel meal. The meal is sold and the largest part of the shells are used in the CHP unit. The POME is treated in lagoons and if these lagoons are not covered the methane produced in these lagoons is emitted to the atmosphere. The water is discharged in the local surface water.

Flow sheets and tables with mass, energy and nutrient flows are presented in Annex 1 (1.1. base case). In Figure 1 a simplified flow sheet is presented focussed on the oil mill residues.

The mass balances are tuned to an oil mill capacity of 1 ton FFB DM/h. That corresponds to 1.67 ton FFB fresh weight/h.

Since 12.2 ton FFB DM can be produced per hectare per year and Malaysia has 4,700,000 ha oil palm plantation area, the amount of FFB produced in Malaysia is 57.2 Mton/year.

POME is stored in an open lagoon without cover. It is assumed that the same amount of methane is produced as in an high rate IC reactor plus sludge digester (see section 3.2). Based on data given in the Alternative $16.85 \mathrm{~kg}$ methane can be produced from $50 \mathrm{~kg}$ POME DM (our base case). HHV (higher heating value) of methane is $55.4 \mathrm{MJ} / \mathrm{kg}$.

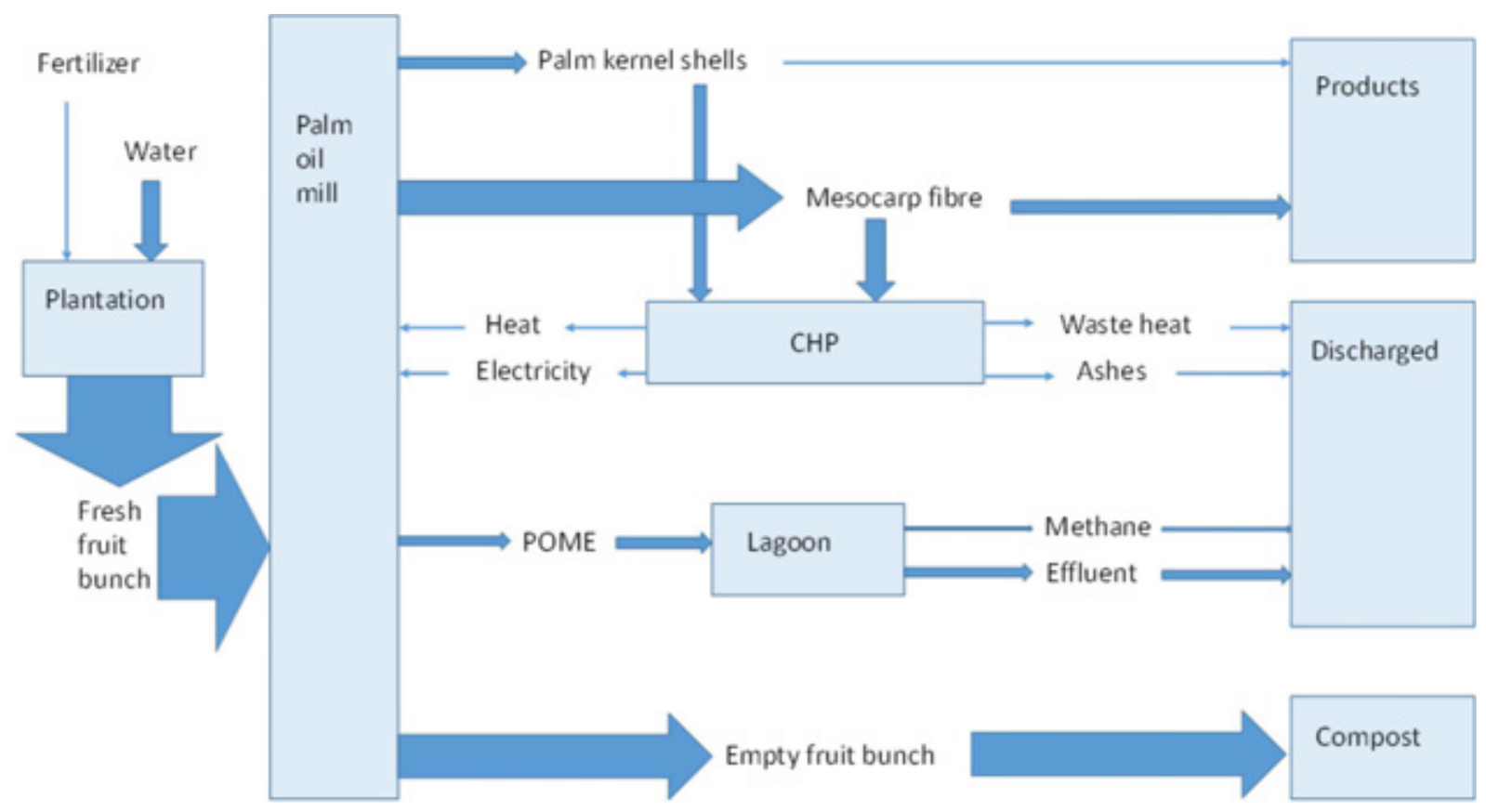

Figure 1 Simplified dry matter flow diagram (plus indication of fresh water requirement) of the base case (business as usual) wit focus on the oil mill residues 


\subsection{Alternative 1: POME conversion into biogas and use of biogas in existing $\mathrm{CHP}$}

POME can be converted into biogas in special anaerobic reactors. The collected biogas can be used to feed the CHP. In the base case mesocarp fibres and palm kernel shells are the fuel of the CHP. By using biogas a part of the palm kernel shells can be saved and can be used as valuable product (export biofuel) instead of a CHP fuel.

Paques offers equipment for POME digestion and treatment. However, this treatment is very much focussed on cleaning the effluent in such way it can be discharged into surface waters or used for irrigation. It is not focussed on maximisation of the biogas production, probably because of the low value of biogas. In our case in which biogas can substitute a part of the palm kernel shells, maximisation of biogas production becomes more interesting.

The equipment includes an oil separator, decanter and dissolved air flotation unit to remove oil, grease and suspended solids. The water, which contains a lower amount of organic matter, is introduced in an IC reactor (anaerobic digester) and is subsequently treated in an (aerobic) activated sludge system. The biogas is treated in a THIOPAQ system to remove a large part of $\mathrm{H}_{2} \mathrm{~S}$. This gas can be used in an existing CHP. ${ }^{1}$ That is worked out in this alternative 1 . The biogas can also be used in another technology: upgrading and compression into CNG for use as transportation fuel (worked out in alternative 2).

In a particular example $720 \mathrm{~m}^{3}$ POME is treated daily. The mass flow of COD is 54.1 ton COD/day. The dry matter flow is estimated 60 ton/day. After removal of oil grease (3.6 ton/day) and suspended solids (21.8 ton DM/day) only 24.7 ton COD/day is left. That is introduced in the IC reactor. From this amount 4.1 ton methane/day is produced, which corresponds with 16.4 ton COD/day. ${ }^{1}$ The COD transfer efficiency, roughly the same as the energy efficiency, is $66 \%$.

Our suggestion is, to maximize the biogas production, and also digest the recovered sludge fraction in a sludge digester. The energy efficiency of that digester may also be $66 \%$. With that addition the biogas production can be doubled to 8.2 ton methane. The total production per ton original POME DM is 0.137 ton methane.

The effluent of the treatment train only contains $20 \mathrm{mg} \mathrm{BOD/L}$ and can be discharged in surface waters. The nitrogen is largely removed by nitrification and denitrification. Since we suggest to use the effluent for plantation irrigation, the removal of nitrogen can be skipped. Activated sludge processes can be adjusted in such way that BOD is removed and ammonia is not.

The treatment plant not only produces an energy carrier (methane) but also consumes energy. The aeration in the activated sludge plant is the largest consumer of energy and requires $5 \%$ of the energy of the biogas (in the original plan). ${ }^{2}$ In the new plan this will be $2.5 \%$ as double amounts of methane are produced. Therefore, we propose to calculate with a nett methane production of 0.134 ton methane per ton POME DM.

The biogas (methane) can be introduced in the CHP. Normally biogas CHP units are different compared to solid fuel CHP units because of the higher temperatures reached. Since the amount of biogas is low compared to the amount of solid fuels no new CHP needs to be purchased. From the tables presented below the effect is that $36 \mathrm{~kg}$ palm kernel shell can be saved and sold as a high quality fuel for export. Alternatively, mesocarp fibres can be saved instead of palm kernel shells.

A second change is the use of POME as irrigation water. That saves the purchase of fertilizer (synthetic nutrients). See Annex 1 section 1.2 for detailed data on mass and energy flows. From these tables the differences with the base case can be formulated as follows:

\footnotetext{
${ }^{1}$ Information given by Paques

2 Information given by Paques
} 
- $\quad 36 \mathrm{~kg}$ palm kernel shells DM (per hour) shift from CHP use to sales.

- $\quad 6.7 \mathrm{~kg}$ methane per hour now recovered and not emitted.

- $\quad 0.37 \mathrm{GJ} / \mathrm{h}$ from palm kernel shells shift from CHP use to sales.

- $\quad 0.37 \mathrm{GJ} / \mathrm{h}$ now recovered as methane from POME and used in the CHP.

- $1 \mathrm{~kg} \mathrm{~N}, 0.15 \mathrm{~kg} \mathrm{P}$ and $2.85 \mathrm{~kg} \mathrm{~K}$ per hour recycled via POME to the plantation.

- Same amount lower input of (synthetic) nutrients.

Figure 2 is a visualisation of the mass flows in the new situation.

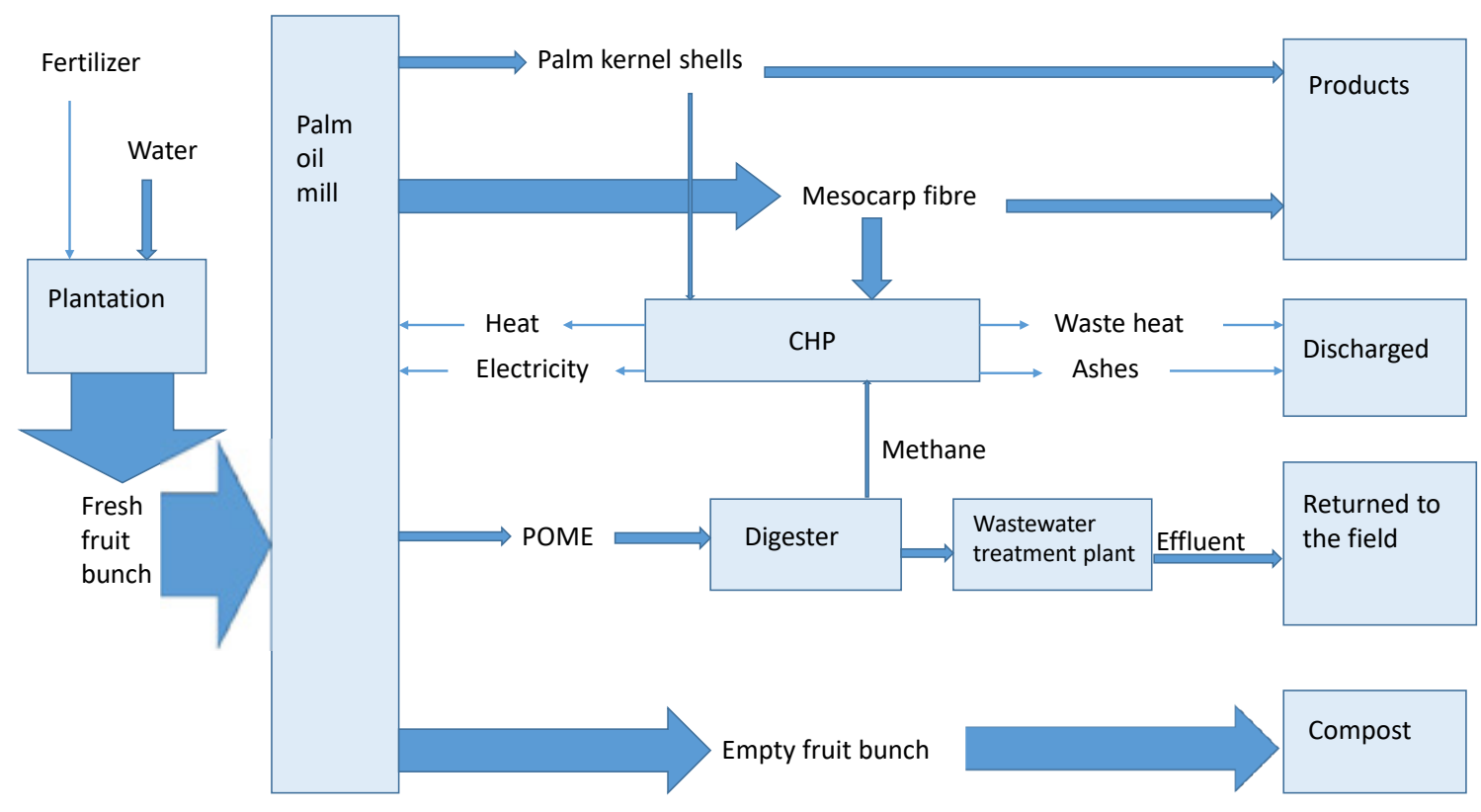

Figure 2 Simplified dry matter flow diagram (plus indication of fresh water requirement) of alternative 1: anaerobic digestion of POME and using the biogas for CHP 


\subsection{Alternative 2: POME conversion into biogas and use of biogas as transportation fuel}

The biogas alternatively can be used as a transportation fuel. In that case a different biogas purification system is required: next to $\mathrm{H}_{2} \mathrm{~S}$ also $\mathrm{CO}_{2}$ have to be removed from the biogas.

DMT is able to offer equipment for biogas purification and preparing the gas for filling in pressure vessels. The equipment comprises:

- $\quad$ Biogas Boosting (to 200 mbar)

- Cooling to $10^{\circ} \mathrm{C}$ dew point

- Desulfurisation (biological scrubber)

- Activated carbon filter

- Chilling

- Compression (16 Bar)

- Membrane $\mathrm{CO}_{2}$ separation

- Compression (250 bar)

- $\quad$ CNG filling (storage and filling station)

The effect is that methane is not emitted in the atmosphere but used as a transportation fuel in cars and trucks instead of diesel. In this case no palm kernel shells are saved. Since the POME is treated in the same equipment (alternative 1) it can be used to irrigate the plantation. That saves the use of purchased fertilizer again.

This type of biogas upgrading and compression to 250 bar requires energy. According to DMT it requires $0.45 \mathrm{kWh}$ per $\mathrm{Nm}^{3}$ unpurified biogas (which contains $59.5 \%$ methane). This is $1.06 \mathrm{kWh}$ or $3.81 \mathrm{MJ}$ per $\mathrm{kg}$ methane. This energy may be derived by using a part of the biogas to produce more energy. A biogasdedicated CHP can be used for that and such CHP has an electric efficiency of $40 \%$. Therefore, it is suggested that $3.81 / 0.40=9.53 \mathrm{MJ}$ is required per $\mathrm{kg}$ methane. Methane has a LHV (lower heating value) of $55.4 \mathrm{MJ} / \mathrm{kg}$, which means that $0.17 \mathrm{~kg}$ methane is required to upgrade $1 \mathrm{~kg}$ methane. In our case $6.7 \mathrm{~kg}$ methane is produced (per ton FFB DM processed): $5.7 \mathrm{~kg}$ can be upgraded while $1 \mathrm{~kg}$ is used to generate energy in the CHP.

The effect of alternative 2 on mass flows, energy and nutrient flows is presented in Annex 1 section 1.3. The most important changes compared to the base case are:

- $\quad 5.7 \mathrm{~kg}$ methane per hour now recovered and sold as transportation fuel, and not emitted.

- $\quad 0.34 \mathrm{GJ} / \mathrm{h}$ now recovered as methane from POME and sold as transportation fuel.

- $\quad 0.012 \mathrm{GJ} / \mathrm{h}$ more electricity and $0.018 \mathrm{GJ} / \mathrm{h}$ more heat loss because of use of a small part of the biogas in CHP.

- $1 \mathrm{~kg} \mathrm{~N}, 0.15 \mathrm{~kg} \mathrm{P}$ and $2.85 \mathrm{~kg} \mathrm{~K}$ per hour recycled via POME to the plantation.

- $\quad$ Same amount lower input of (synthetic) nutrients.

Figure 3 shows the new mass flows. 


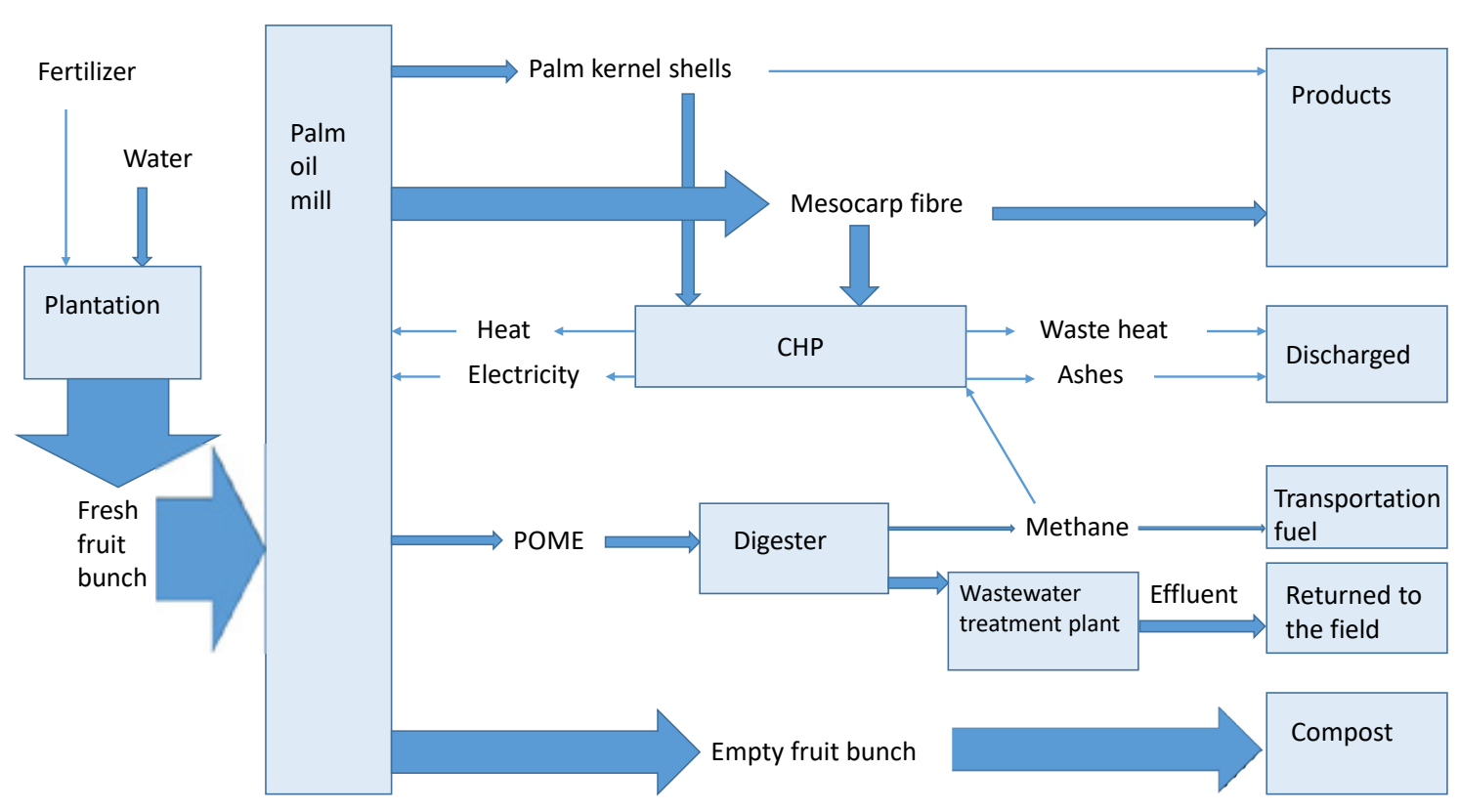

Figure 3 Simplified dry matter flow diagram (plus indication of fresh water requirement) of alternative 2: anaerobic digestion of POME and using the biogas as a transportation fuel 


\subsection{Alternative 3: EFB conversion into black pellets (by TORWASH $®$ )}

In the base case EFB is composted and sold as compost. In alternative 3 EFB is used to produce a high value fuel for export. Fresh EFB contains too much minerals to act as a fuel (in particular potassium is problematic) and has a low density. A part of the minerals can be removed by washing with water and a densification can be carried out by torrefaction followed by pelletization. By this action black pellets are produced that are dense and has a higher calorific value per kg dry matter, moreover the material is hydrophobic: it repels water, which makes storage and transport (shipping) easier. Washing and torrefaction can be carried out in separate unit operations, but also in a combined process: TORWASH®.

According to ECN (TNO) EFB can be converted into black pellets using the following unit operations:

- TORWASH® reactor

- $\quad$ post washing

- dewatering

- $\quad$ post drying

- $\quad$ pelletizing

The effluents from post washing and dewatering can be treated in an anaerobic digester (UASB reactor)

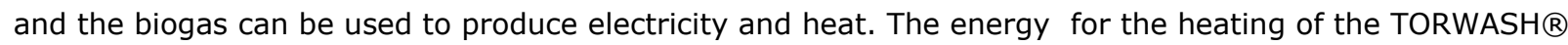
reactor can be derived from the biogas-dedicated CHP. Post drying can be carried out using residue heat from the CHP and the complete electricity requirement can be produced in the CHP from the biogas derived from the EFB wash effluent.

According to Blackwood Technology chipping, sizing and sieving is required before torrefaction.

According to ECN (TNO) in the TORWASH and pelletization process 5.1 ton EFB dry is converted into 4.2 ton black pellets. The difference (0.9 ton DM) is dissolved in the effluent.

In our mass balance 0.24 ton EFB DM/h will lead to the production of 0.198 ton black pellets DM/h and 0.042 ton $\mathrm{DM} / \mathrm{h}$ is dissolved in the effluent.

By TORWASH® $83 \% \mathrm{~N}, 86 \% \mathrm{P}$ and $96 \% \mathrm{~K}$ is removed from the solid fraction.

According to ECN (TNO) washed/torrefied material (black pellets) has a 10\% higher energy content than brown pellets (original dry material). According to Blackwood Technologies dry EFB has a LHV of $17 \mathrm{MJ} / \mathrm{kg}$ and washed and torrefied material $20.4 \mathrm{MJ} / \mathrm{kg}$ dry matter. That is an increase of $20 \%$. In our study we will calculate with $10 \%$ increase as it better fits in the mass balance given by ECN (TNO).

According to ECN (TNO) two types of wash water are used: (1) about 3 ton POME per ton EFB dry matter and (2) 0.75 ton fresh water per ton EFB. Actually, the solids in the POME are torrefied as well by this method, but for now this effect will neglected, to separate various GHG emission effects. Nevertheless, we will calculate only with 0.75 ton fresh water for washing.

The effect of alternative 3 on mass flows, energy and nutrient flows is presented in Annex 1 section 1.4. The most important changes compared to the base case are:

- Empty fruit bunch now used to produce black pellets for export (198 kg DM/h).

- $\quad 4.57 \mathrm{GJ} / \mathrm{h}$ from EFB in form of black pellets for export.

- $\quad 1.19 \mathrm{~kg} \mathrm{~N}, 0.21 \mathrm{~kg} \mathrm{P}$ and $3.44 \mathrm{~kg} \mathrm{~K}$ per hour recycled via EFB TORWASH ${ }^{\circledR}$ to the plantation.

- Same amount lower input of (synthetic) nutrients.

Figure 4 visualizes the new situation. 


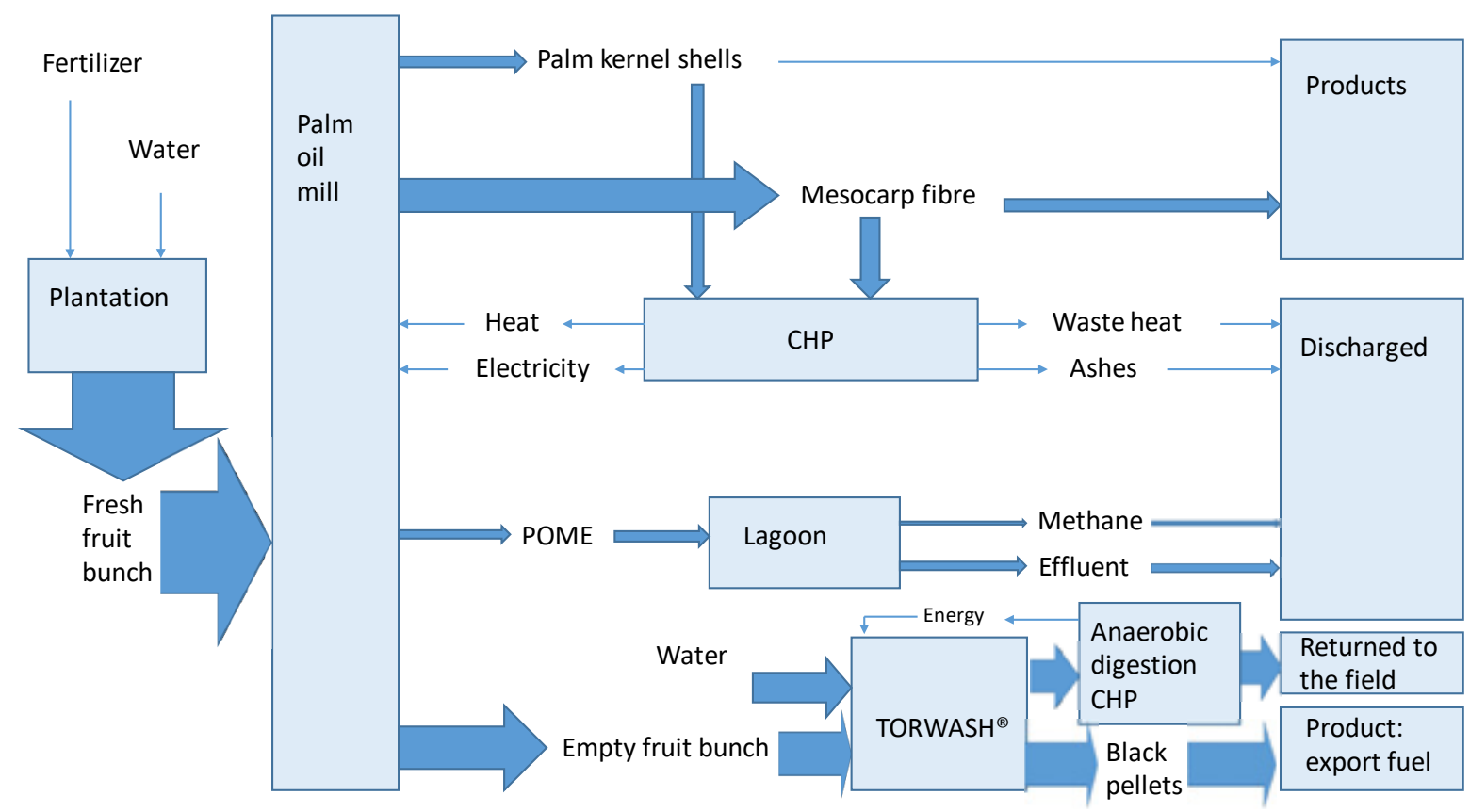

Figure 4 Simplified dry matter flow diagram (plus indication of fresh water requirement) of alternative 3: TORWASH of empty fruit bunch and using the black pellets as export fuel 


\subsection{Alternative 4: EFB washing and feeding in the existing CHP}

In alternative $3 \mathrm{EFB}$ is transformed into a fuel that can be exported. In alternative 4 the EFB is washed and fed in a rather wet state in the CHP to produce energy for the oil mill. This way all mesocarp fibre and palm kernel shells can be saved and sold as high value products.

In this case the EFB is washed in a counter-current washing system as developed by WFBR. After washing the EFB is pressed. Based on experience in WFBR laboratory experiments it was found that before washing the EFB contains 40\% DM, after washing 35\% DM and after pressing 50\% DM. Two litre water is required per $\mathrm{kg}$ DM. Ten percent of the COD is washed out and at least $90 \%$ of potassium. Our educated guess is that $10 \%$ of nitrogen and $50 \%$ of $P$ is washed out as well. Most probably $10 \%$ of the total DM and $10 \%$ of the energy content is washed out. The nature of the organic material that is washed out is poorly biodegradable (such as humic acids) and will not consume much oxygen when added to soil therefore, the water can be used as irrigation water.

The assumption is that the salts are mostly removed allowing efficient thermal conversion (less slagging and corrosion problems) Since the most harmful minerals are washed out, the material is fit to be used as a fuel in the existing CHP (Meesters \& Elbersen, 2018). The wet EFB (50\% DM) may be first dried. But a cost saving option is not to dry it and use it as wet material in the CHP. The efficiencies in the CHP will be lower then: $3.6 \%$ of the HHV is converted into electricity, $54.5 \%$ as heat that can be used in the oil mill and $41.9 \%$ is lost as heat via the off-gas stack.

The amount of electricity and useful heat produced almost fulfils the need of the oil mill. A small amount of palm kernel shells (PKS) is still required to fill up the gap and to use as a starter fuel in the CHP (cannot be started with wet biomass). We need $0.96 \mathrm{GJ} \mathrm{PKS} / \mathrm{h}$ (46 kg PKS/h) for that purpose.

This action saves the complete amount of mesocarp fibre and recovers a large part of the nutrients from EFB to be recycled to the plantation.

The effect of alternative 4 on mass flows, energy and nutrient flows is presented in Annex 1 section 1.5 . The most important changes compared to the base case are:

- $\quad 15 \mathrm{~kg}$ palm kernel shells DM (per hour) shift from CHP use to sales

- 216 kg EFB DM per hour now recovered, washed and use in CHP

- $\quad 0.30 \mathrm{GJ} / \mathrm{h}$ from palm kernel shells shift from CHP use to sales

- $\quad 4.54 \mathrm{GJ} / \mathrm{h}$ mesocarp fibres shift from CHP to sales

- $\quad$ EFB now washed and used as fuel in $\operatorname{CHP}(4.51 \mathrm{GJ} / \mathrm{h})$

- $0.05 \mathrm{GJ} / \mathrm{h}$ additional heat loss

- $\quad 0.14 \mathrm{~kg} \mathrm{~N}, 0.12 \mathrm{~kg} \mathrm{P}$ and $3.22 \mathrm{~kg} \mathrm{~K}$ per hour recycled via EFB washing to the plantation.

- Same amount lower input of (synthetic) nutrients

In Figure 5 the new situation is depicted. 


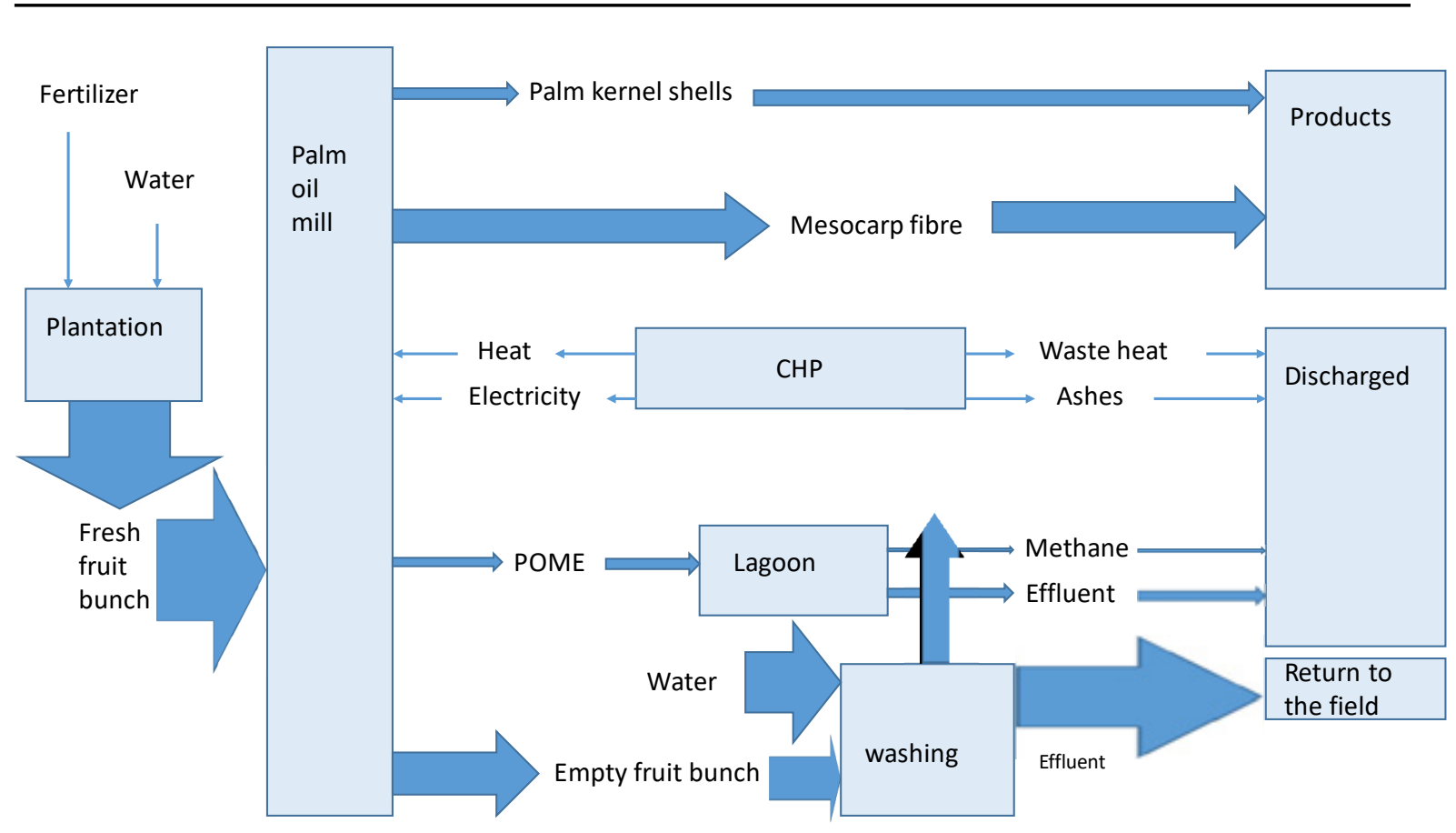

Figure 5 Simplified dry matter flow diagram (plus indication of fresh water requirement) of alternative 4: washing of empty fruit bunch and using the washed EFB for CHP 


\subsection{Alternative 5: combination of using biogas from POME and washed EFB in the existing CHP}

By combining alternative 1 and 4 both methane emissions to the atmosphere can be avoided and a maximum amount of mesocarp and palm kernel shells can be saved and sold as a high value fuel for export. Moreover, nutrients from POME and a part of the nutrients from EFB can be recycled to the plantation, which leads to a lower purchase of fertilizers.

The CHP will be fuelled with biogas, washed EFB and palm kernel shells, each fuel with its own conversion efficiencies. See Table 1 and Table 2.

Table 1 Efficiencies in an existing CHP unit in dependence of the fuel.

\begin{tabular}{lccc} 
& Biogas & Wet EFB & PKS \\
$\begin{array}{l}\text { Efficiency production of } \\
\text { electricity }\end{array}$ & $4.9 \%$ & $3.6 \%$ & $4.4 \%$ \\
\hline $\begin{array}{l}\text { Efficiency production of heat } \\
\text { that can be used }\end{array}$ & $73.2 \%$ & $54.5 \%$ & $68.9 \%$ \\
\hline Waste heat part & & & \\
\hline
\end{tabular}

Table 2 All fuels used in the CHP in alternative 5.

\begin{tabular}{|c|c|c|c|c|c|}
\hline & $\begin{array}{l}\text { The oil mill } \\
\text { requires per ton } \\
\text { FFB DM/h: }\end{array}$ & $\begin{array}{l}\text { Biogas input } \\
(0.37 \mathrm{GJ} / \mathrm{h})\end{array}$ & $\begin{array}{l}\text { Washed EFB } \\
\text { input ( } 4.51 \\
\text { GJ/h) }\end{array}$ & $\begin{array}{l}\text { PKS input } \\
(0.567 \mathrm{GJ} / \mathrm{h})\end{array}$ & $\begin{array}{l}\text { Result (total) } \\
(\mathrm{GJ} / \mathrm{h})\end{array}$ \\
\hline Electricity & $0.20 \mathrm{GJ} / \mathrm{h}$ & 0.018 & 0.16 & 0.025 & 0.20 \\
\hline $\begin{array}{l}\text { Heat that can be } \\
\text { used by the mill }\end{array}$ & $3.12 \mathrm{GJ} / \mathrm{h}$ & 0.27 & 2.46 & 0.391 & 3.12 \\
\hline Heat loss (chimney) & & 0.081 & 1.89 & 0.151 & 2.12 \\
\hline
\end{tabular}

Since our system processes 1 ton FFB DM per hour all energy consumptions expressed as GJ/h have the same numbers if expressed as GJ/ton FFB DM.

The effect of alternative 5 on mass flows, energy and nutrient flows is presented in Annex 1 section 1.6. The most important changes compared to the base case are:

- $\quad 34 \mathrm{~kg}$ palm kernel shells DM (per hour) shift from CHP use to sales

- $220 \mathrm{~kg}$ mesocarp fibre DM (per hour) shift from CHP use to sales

- $\quad$ EFB now utilized, washed and used in CHP (216 kg DM/h).

- $\quad 0.69 \mathrm{GJ} / \mathrm{h}$ from palm kernel shells shift from CHP use to sales

- $\quad 4.54 \mathrm{GJ} / \mathrm{h}$ mesocarp fibres shift from CHP to sales

- $\quad$ EFB now washed and used as fuel in CHP (4.51 GJ/h)

- $\quad 0.37 \mathrm{GJ} / \mathrm{h}$ now recovered as methane from POME and used in the CHP

- $0.02 \mathrm{GJ} / \mathrm{h}$ additional heat loss in $\mathrm{CHP}$

- $1 \mathrm{~kg} \mathrm{~N}, 0.15 \mathrm{~kg} \mathrm{P}$ and $2.85 \mathrm{~kg} \mathrm{~K}$ per hour recycled via POME to the plantation.

- $\quad 0.14 \mathrm{~kg} \mathrm{~N}, 0.12 \mathrm{~kg} \mathrm{P}$ and $3.22 \mathrm{~kg} \mathrm{~K}$ per hour recycled via EFB washing to the plantation.

- $\quad 1.14 \mathrm{~kg} \mathrm{~N}, 0.27 \mathrm{~kg} \mathrm{P}$ and $6.07 \mathrm{~kg} \mathrm{~K}$ per hour lower input of (synthetic) nutrients .

Figure 6 visualises the new situation. 


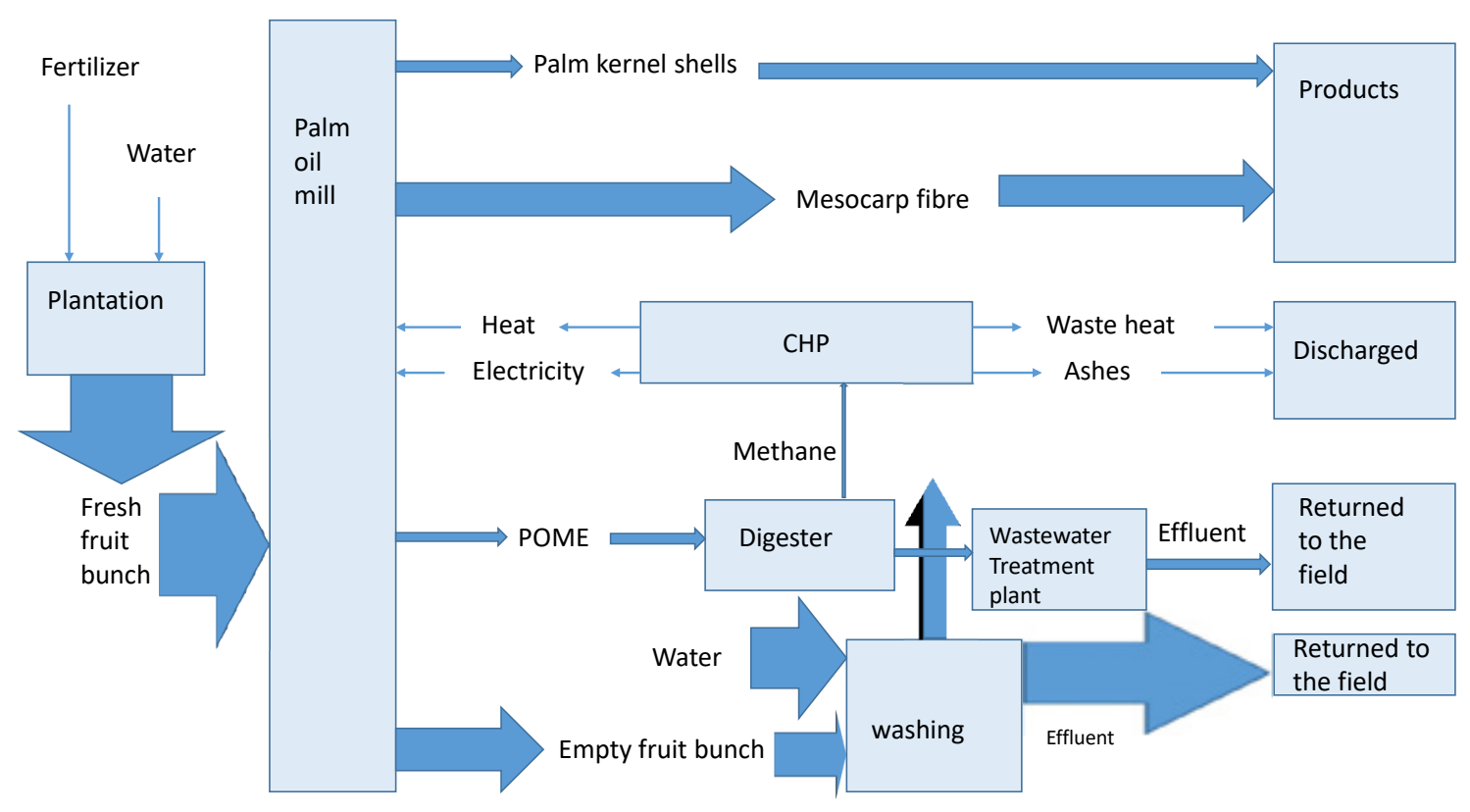

Figure 6 Simplified dry matter flow diagram (plus indication of fresh water requirement) of alternative 5: washing of empty fruit bunch and using the washed EFB for CHP combined with anaerobic digestion of POME and using the biogas for CHP 


\section{Economic assessment of the alternatives}

\subsection{Preamble}

The utilization of palm oil mill residues requires processing and therefore equipment. As a consequence investment costs are involved and in addition operational costs. These costs can be compared to the benefits gained by the new operation. These benefits may be the production of high quality fuels that can be sold on the market or nutrients that can be saved. Mesocarp fibres, palm kernel shells, transportation fuel, black pellets and saved fertilizers are all valuable. Costs and benefits of all five alternatives are estimated and compared.

Investment costs depend on the capacity of the oil mill. In this section an oil mill that processes 60 ton FFB per hour ( 36 ton FFB DM/h) was taken as a representative example and the investment costs were based on such capacity.

A large part of the annual costs are derived from the CAPEX:

- Depreciation and interest: $12 \%$ of the CAPEX for all equipment except DMT equipment

- Depreciation and interest: 7\% of the CAPEX for DMT equipment (life time 20 years)

- Maintenance and insurance: $6 \%$ of the CAPEX

\subsection{Alternative 1: POME conversion into biogas and use of biogas in an existing CHP}

A mill that processes 36 ton FFB DM/h and 6500 operation hours per year produces an average flow of POME equivalent to an energy flow of $7.79 \mathrm{MW}$. Anaerobic digesters are required for production of biogas. No cost estimate was given by Paques. Instead, the investment costs for anaerobic digestion including gas purification were taken from Uslu et al. (2018), who estimated the CAPEX for digesters that process 7.79

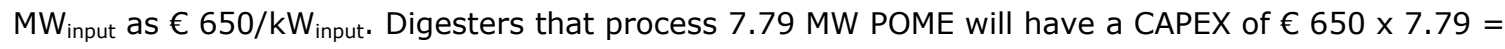
$€ 5,100.000$. However, in countries outside the Netherlands CAPEX can be lower. According to IFC (2017) biogas plants (in this capacity range) in regions/countries other than Europe, USA, South-Africa, China and India has a CAPEX of $2 / 3$ of that in Europe. That would make the CAPEX in Malaysia lower. Besides digesters an aerobic post-treatment is required to produce water that is fit to be used for irrigation. Such aerobic post-treatment also is foreseen by Paques. This addition will increase the CAPEX. Eventually, the total the CAPEX for the complete POME treatment train may be near M€ 4.5. This investment is made to fulfil two functions: (1) treatment of the wastewater and (2) production of methane. In this report we focus on methods to utilize residue biomass, therefore only function 2 is relevant. We propose to allocate half of the investments to water cleaning and the other half to methane production ( $M € 2.25$ ).

An estimation of the annual costs are summarized in Table 3.

Table 3 Annual costs of POME digester and aerobic post-treatment.

\begin{tabular}{ll} 
Item & Annual costs \\
Depreciation and interest & $€ 270,000$ \\
\hline Maintenance, tax and insurance & $€ 135,000$ \\
\hline Labour & Low \\
\hline Energy & Already accounted for internally \\
\hline Chemicals & Low \\
\hline TOTAL & $\mathbf{C 4 0 5 , 0 0 0}$ \\
\hline
\end{tabular}

In this mill 36 ton FFB DM/h is processed in 6500 operational hours per year. The costs for production of methane equals $€ 1.73$ per ton FFB DM. 
Benefit 1 is created by the use of biogas in the existing CHP. Because of this alternative fuel an additional $36 \mathrm{~kg}$ palm kernel shells (per ton FFB DM) can be saved and offered on the international market as a fuel for power plants. The value of the shells is estimated using the average free-on-board prices for Indonesian ports in 2018 , which was US\$ 80 /ton palm kernel shells ( $90 \%$ dry matter) (www.palmkernelshell.id/palm-kernel-shell-price/). This may price may be comparable with ports in Malaysia. Price increases are expected over time. Overland transportation in Malaysia may cost up to $€ 20$ /ton DM (estimation Juliën Voogt, WFBR cost engineer involved in palm oil mill projects). Therefore, the unprocessed palm kernel shells at the gate of the oil mill may have a value of $€ 70 /$ ton DM. The value of $36 \mathrm{~kg}$ is $€ 2.52$.

Benefit 2 is the fact that the clean water is used as irrigation water and can save the purchase of fertilizer. Per ton FFB DM the amounts of fertilizers shown in Table 4 can be saved.

Table 4 Amounts of fertilizers saved per ton FFB DM.

\begin{tabular}{lll} 
Amount saved & Price (Voogt et al., 2018) & Saved \\
$1 \mathrm{~kg} \mathrm{~N}$ & $€ 400 /$ ton N & $€ 0.40$ \\
\hline $0.15 \mathrm{~kg} \mathrm{P}$ & $€ 687 /$ ton P & $€ 0.10$ \\
\hline $2.85 \mathrm{~kg} \mathrm{~K}$ & $€ 435 /$ ton K & $€ 1.24$ \\
\hline TOTAL & & $\mathbf{C 1 . 7 4}$ \\
\hline
\end{tabular}

The costs and benefits can be compared:

- Costs: $€ 1.73$ per ton FFB DM

- $\quad$ Benefits (1 plus 2): $€ 4.26$ per ton FFB DM

This means that alternative 1 seems economically viable.

The return of investment can be expressed by the number of years the investment can be paid back by the profit (now calculated without the annual depreciation and interest).

Investment costs: $M € 2.25$

Annual costs without depreciation and interest: $€ 405,000-€ 270,000=€ 135,000$

Annual benefits: $36 \times 6500 \times € 4.26=€ 996,840$

Payback time: M€ 2.25 / ( $€ 996,840-€ 135,000)=2.6$ years

\subsection{Alternative 2: POME conversion into biogas and use of biogas as transportation fuel}

Again a mill that processes 36 ton FFB DM/h (6500 operation hours per year) is considered for estimation of the CAPEX. The same anaerobic digesters are required as in alternative 1 . In addition, equipment is added to further purify (upgrade) the biogas and compress it. The gas is sold as transportation fuel. DMT, supplier of the gas purification and compression units, has estimated that the CAPEX for gas upgrading is $M € 1.3$ and for compression M€ 0.25 . The total CAPEX is M€ 1.55. The lifetime is 20 years, therefore, annual depreciation and interest amounts $7 \%$ of the CAPEX. The investment costs for the biogas-dedicated $\mathrm{CHP}$ in which a part of the biogas is used the produce electricity for the compressors is not included (but the benefit of additional heat production is not included as well). The equipment is designed to upgrade $800 \mathrm{Nm}^{3}$ biogas/h. This is in the same order of magnitude as the capacity studied in this report (360 $\mathrm{Nm}^{3}$ biogas $(\mathrm{h})$. The raw biogas contains $59.7 \%$ methane, therefore, the capacity of the plant in the model of DMT is $341 \mathrm{~kg}$ methane/h. The annual costs for upgrading and compression are shown in Table 5. 
Table 5 Annual costs for upgrading and compression of biogas.

\begin{tabular}{ll} 
Item & Annual costs \\
Depreciation and interest & $€ 109,000$ \\
\hline Maintenance, tax and insurance & $€ 93,000$ \\
\hline Labour & Low \\
\hline Energy & Already accounted for internally \\
\hline Chemicals & Low \\
TOTAL & $\mathbf{C 2 0 2 , 0 0 0}$
\end{tabular}

This translates to $€ 0.11$ per $\mathrm{kg}$ compressed methane.

In alternative $25.7 \mathrm{~kg}$ methane is upgraded and compressed per ton FFB DM processed. Therefore, upgrading and compression cost $€ 0.63$ per ton FFB DM.

The costs for biogas production from POME is the same as in alternative $1: € 1.73$ per ton FFB DM. In total the costs for the production of transportation grade methane are $€ 2.36$.

Benefit 1 is the sales of $5.7 \mathrm{~kg}$ methane (per ton FFB DM) as transportation fuel. No prices of this fuel are readily available yet in Malaysia, but LPG cost 30 RM/MMBTU (million British thermal units)

(www.gasmalaysia.com) and Harmen Dekker (personal communication) informed us that the compressed methane (CNG) can be sold for $35 \mathrm{RM} / \mathrm{MMBTU}$ to the industry (that is the price the producer of the CNG can get). MMBTU equals $1.06 \mathrm{GJ}$; methane has a HHV of $55.4 \mathrm{MJ} / \mathrm{kg} ; 1 \mathrm{RM}$ has a value of $€ 0.21$. The conclusion is that methane may be sold for a price of $€ 0.36 / \mathrm{kg} .5 .7 \mathrm{~kg}$ methane can be sold for $€ 2.05$. Benefit 2 is the fact that the clean water is used as irrigation water and can save the purchase of fertilizer. The same amounts as alternative 1 are saved: $€ 1.74$ per ton FFB DM.

The costs and benefits can be compared:

- $\quad$ Costs: $€ 2.36$ per ton FFB DM

- $\quad$ Benefits (1 plus 2): $€ 3.79$ per ton FFB DM

This means that alternative 2 seems economically viable.

Calculation of the time period in which return of investment can be expected:

Investment costs: $M € 2.25+M € 1.55$

Annual costs without depreciation and interest: $€ 135,000+€ 202,000-€ 109,000=€ 228,000$

Annual benefits: $36 \times 6500 \times € 3,79=€ 886,860$

Payback time: (M€ $2.25+$ M€ 1.55) / $(€ 886,860-€ 228,000)=5.8$ years

\subsection{Alternative 3: EFB conversion into black pellets (by TORWASH $®)$}

Again a mill that processes 36 ton FFB DM/h is considered. The CAPEX for the complete train: TORWASH $\mathbb{R}$ reactor, post washing, dewatering, post drying, pelletizing, UASB reactor and CHP, is estimated 4 to 8 million Euro by ECN (part of TNO). The annual costs are given in Table 6.

Table 6 Annual costs for washing and torrefaction of EFB.

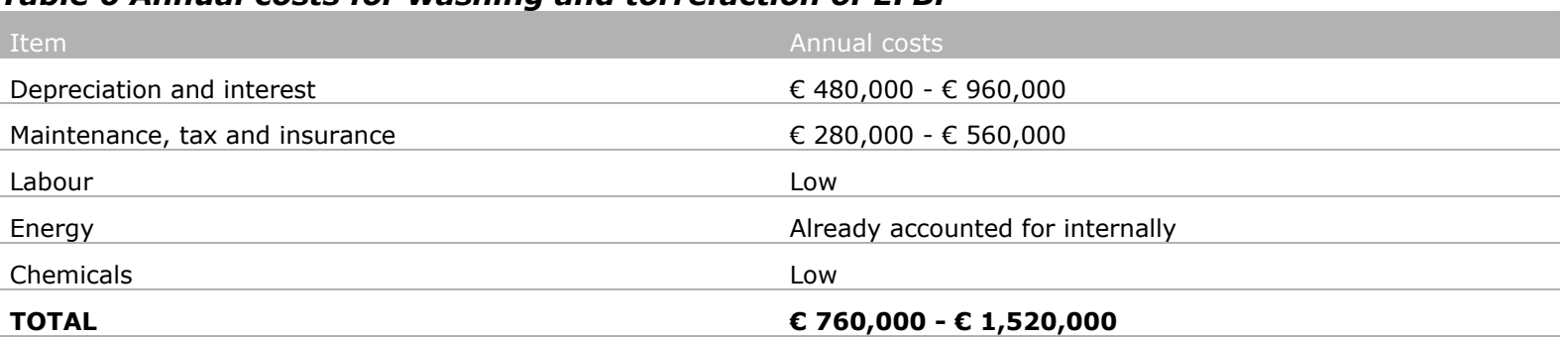


This translates to $€ 3.25$ to $€ 6.50$ per ton FFB DM (36 ton FFB DM per hour and 6500 operational hours per year).

Benefit 1 is the sales of $198 \mathrm{~kg}$ black pellets per ton FFB DM processed. According to ECN the value of the black pellets at the gate of the oil mill amounts $\$ 120-\$ 140$ per ton, which equals $€ 108$ to $€ 126$ per ton. This translates to $€ 21.38$ to $€ 24.95$ per ton FFB DM processed.

Benefit 2 is the fact that a large part of the minerals are recovered that can be recycled to the plantation and can save the purchase of fertilizer. The amounts and value per ton FFB DM are shown in Table 7.

Table 7 Amounts of fertilizers saved per ton FFB DM.

\begin{tabular}{lll} 
Amount saved & Price (Voogt et al., 2018) & Saved \\
$1.19 \mathrm{~kg} \mathrm{~N}$ & $€ 400 /$ ton N & $€ 0.48$ \\
\hline $0.21 \mathrm{~kg} \mathrm{P}$ & $€ 687 /$ ton P & $€ 0.14$ \\
\hline $3.44 \mathrm{~kg} \mathrm{~K}$ & $€ 435 /$ ton K & $€ 1.50$ \\
\hline TOTAL & & $\mathbf{C 2 . 1 2}$ \\
\hline
\end{tabular}

The costs and benefits can be compared:

- Costs: $€ 3.25$ to $€ 6.50$ per ton FFB DM

- $\quad$ Benefits (1 plus 2): $€ 23.50-27.07$ per ton FFB DM

This means that alternative 3 seems economically favourable.

Calculation of the time period in which return of investment can be expected:

Investment costs (average): $M € 6$

Annual costs without depreciation and interest (average): $€ 1,140,000-€ 720,000=€ 420,000$

Annual benefits: $36 \times 6500 \times € 3,79=€ 886,860$

Payback time: (M€ $2.25+$ M€ 1.55) / (€ 886,860 - $€ 228,000)=5.8$ years

\subsection{Alternative 4: EFB washing and feeding in the existing $\mathrm{CHP}$}

Washing of EFB takes place as an operation in the following sequence of unit operations: press, shredder, counter-current extraction and second press. The first press already is present at the oil mill, the other four unit operations are additions. Meesters and Elbersen (2018) made an estimation of the investment costs connected to these additions for a mill that processes 40,000 EFB DM/year (which is larger but in the same order of magnitude as the oil mill that processes 60 ton FFB per hour). The CAPEX was estimated $€$ 938,000 . For an estimation of the annual costs and costs per ton EFB DM first the costing method of our current study is used (Table 8).

Table 8 Annual costs for washing EFB.

\begin{tabular}{ll} 
Item & Annual costs \\
Depreciation and interest & $€ 113,000$ \\
\hline Maintenance, tax and insurance & $€ 94,000$ \\
\hline Labour & Low \\
\hline Electricity & $€ 28,000$ \\
Water & $€ 16,000$ \\
\hline TOTAL & $\mathbf{C 2 5 1 , 0 0 0}$
\end{tabular}

The washing costs are $€ 6.28$ per ton EFB dry matter, which is very close to the estimation by Meesters and Elbersen (2018), namely $€ 6.50$ per ton EFB dry matter. Counting with $€ 6.28$ and taking into account that 0.24 ton EFB DM is produced per ton FFB DM, the washing operation will cost about $€ 1.51$ per ton FFB DM processed. 
Benefit 1 is created by the use of washed EFB in the CHP. Because of this alternative fuel an additional 15 $\mathrm{kg}$ palm kernel shells and $216 \mathrm{~kg}$ mesocarp fibres (per ton FFB DM) can be saved and offered on the international market as a fuel for power plants. In alternative 1 it was estimated that the palm kernel shells may have a value of $€ 70 /$ ton. It is assumed that the same is true for mesocarp fibres. The total benefit amounts $€ 16.17$ per ton of FFB DM processed.

Benefit 2 is the fact that the EFB wash water is used as irrigation water and can save the purchase of fertilizer. Per ton FFB DM the amounts of fertilizers shown in Table 9 can be saved.

Table 9 Amounts of fertilizer saved per ton ton FFB DM.

\begin{tabular}{lll} 
Amount saved & Price (Voogt et al., 2018) & Saved \\
$0.14 \mathrm{~kg} \mathrm{~N}$ & $€ 400 /$ ton N & $€ 0.06$ \\
\hline $0.12 \mathrm{~kg} \mathrm{P}$ & $€ 687 /$ ton P & $€ 0.08$ \\
\hline $3.22 \mathrm{~kg} \mathrm{~K}$ & $€ 435 /$ ton K & $€ 1.40$ \\
\hline TOTAL & & $\boldsymbol{C 1 . 5 4}$ \\
\hline
\end{tabular}

The costs and benefits can be compared:

- Costs: $€ 1.51$ per ton FFB DM

- $\quad$ Benefits ( 1 plus 2 ): $€ 17.71$ per ton FFB DM

This means that alternative 4 seems economically favourable.

Calculation of the time period in which return of investment can be expected:

Investment costs: M€ 0.94

Annual costs without depreciation and interest: $€ 251,000-€ 113,000=€ 138,000$

Annual benefits: $36 \times 6500 \times € 17.71=€ 4,144,140$

Payback time: $M € 0.94 /(€ 4,140,140-€ 138,000)=0.23$ years

\subsection{Alternative 5: combination of using biogas from POME and washed EFB in the existing CHP}

The same anaerobic digestion as described in alternative 1 is used. The costs for production of methane equals $€ 1.73$ per ton FFB DM. In addition, the EFB is washed with the method described in alternative 4 . The costs of that operation amounts $€ 1.51$ per ton FFB DM. The sum of these two costs equals $€ 3.24$ per ton FFB DM.

Benefit 1 is created by the use of biogas plus washed EFB in the CHP. Because of these alternative fuels an additional $34 \mathrm{~kg}$ palm kernel shells and $220 \mathrm{~kg}$ mesocarp fibres (per ton FFB DM) can be saved and offered on the international market as a fuel for power plants. The value of mesocarp fibres are the same as palm kernel shells: $€ 70 /$ ton DM at the gate of the oil mill. The total benefit amounts $€ 19.29$ per ton of FFB DM processed.

Benefit 2 is the fact that the clean water from POME and the EFB wash water are used as irrigation water and can save the purchase of fertilizer. Per ton FFB DM the amounts of fertilizers shown in Table 10 can be saved. 
Table 10 Amounts of fertilizers saved per ton FFB DM.

\begin{tabular}{lll} 
Amount saved & Price (Voogt et al., 2018) & Saved \\
$1.14 \mathrm{~kg} \mathrm{~N}$ & $€ 400 /$ ton N & $€ 0.46$ \\
\hline $0.27 \mathrm{~kg} \mathrm{P}$ & $€ 687 /$ ton P & $€ 0.19$ \\
\hline $6.07 \mathrm{~kg} \mathrm{~K}$ & $€ 435 /$ ton K & $€ 2.64$ \\
\hline TOTAL & & $\boldsymbol{C 3 . 2 9}$ \\
\hline
\end{tabular}

The costs and benefits can be compared:

- Costs: $€ 3.24$ per ton FFB DM

- $\quad$ Benefits (1 plus 2): $€ 22.58$ per ton FFB DM

This means that alternative 5 seems economically favourable.

Calculation of the time period in which return of investment can be expected:

Investment costs: $M € 2.25+M € 0.94$

Annual costs without depreciation and interest: $€ 135,000+€ 138,000=€ 273,000$

Annual benefits: $36 \times 6500 \times € 22,58=€ 5,283,720$

Payback time: (M€ 2.25 + M€ 0.94) / ( € 5,283,720- $€ 273,000)=0.64$ years 


\section{$5 \quad$ Environmental impact assessment}

\subsection{Pathways}

Alternative processing pathways for valorisation of Malaysian palm oil industry residues:

1. Base case: business as usual (POME discharged, EFB for compost)

2. Alternative 1: POME conversion into biogas and use of biogas in an existing $\mathrm{CHP}$

3. Alternative 2: POME conversion into biogas and use of biogas as transportation fuel

4. Alternative 3: EFB conversion into black pellets (by TORWASH ${ }^{\circledR}$ )

5. Alternative 4: EFB washing and feeding in the existing CHP

6. Alternative 5: combination of using biogas from POME and washed EFB in the existing CHP

\subsection{Life Cycle Inventory}

\subsubsection{Process flow diagrams}

The process flow diagram of the base case is seen in Figure 7. The main product is crude palm oil and coproducts palm kernel meal and palm kernel oil are produced. Mesocarp fibre and palm kernel shells are used internally to supply the heat and power demand. Some excess fibre and shells are produced but according to RED they are defined as residues and therefore no emission should be allocated to these as co-products.

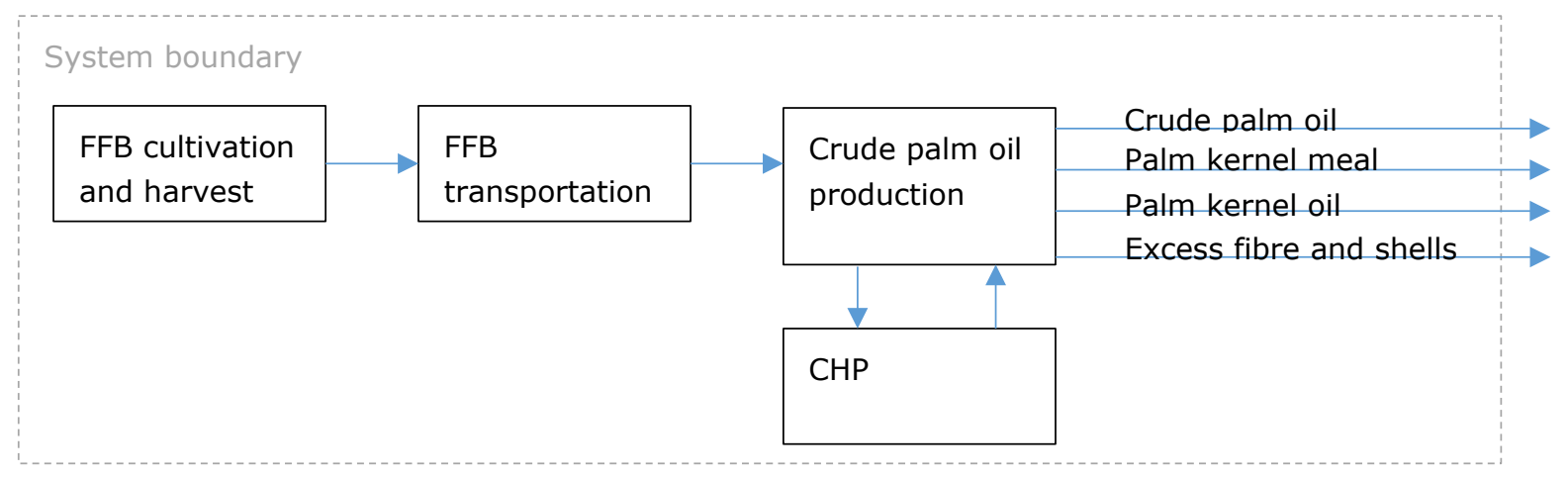

Figure 7 Process flow diagram of base case

The process flow diagram of the case Alternative 1 is seen in Figure 8 . As in the base case, the main product is crude palm oil and co-products palm kernel meal and palm kernel oil are produced. The difference with the base case is POME, which is discharged in the base case, is used to produce biogas. This allows the emissions from POME discharge to be avoided. The biogas produced is used in CHP to supply internal energy. This results in lower requirement of mesocarp fibre and shells to supply internal energy demand. According to RED the excess fibre and shells produced are defined as residues and therefore no emission should be allocated to these as co-products. The difference in GHG impact is seen in the difference in emissions emitted in the CHP with some amount of shells being replaced with POME derived biogas. Furthermore, the effluent from the POME digestion is returned to field which results in lower external fertilizer requirement. 


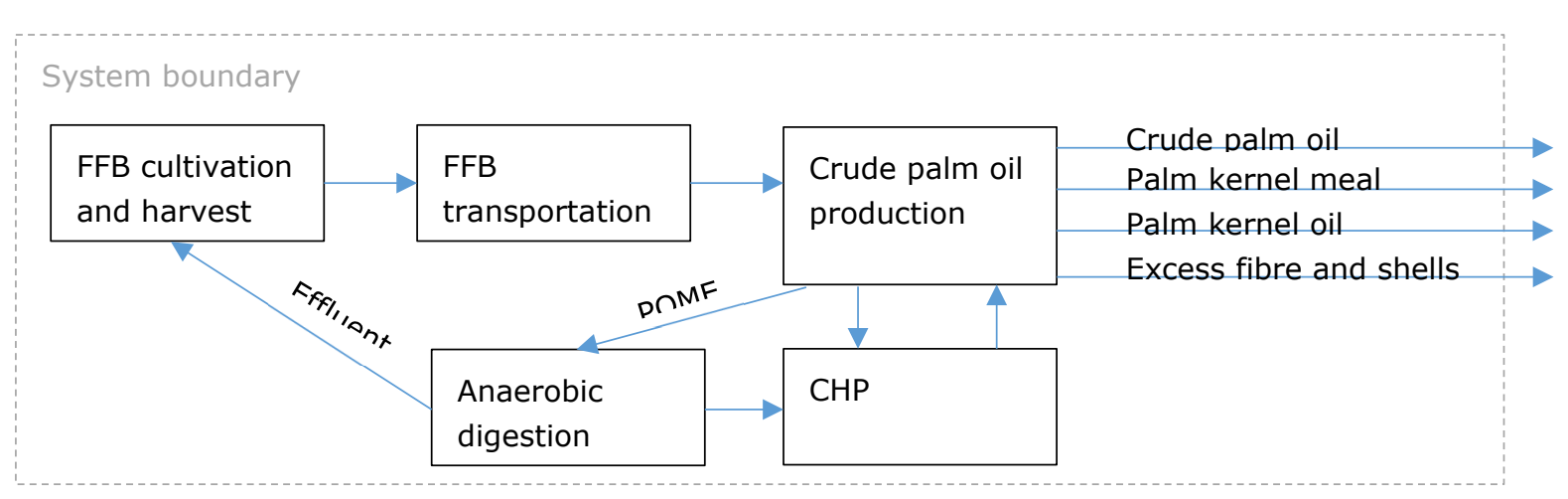

Figure 8 Process flow diagram of Alternative 1: POME conversion into biogas and use of biogas in an exsiting CHP

The process flow diagram of the case Alternative 2 is seen in Figure 9. As in the base case, the main product is crude palm oil and co-products palm kernel meal and palm kernel oil are produced. The difference with the base case is POME, which is discharged in the base case, is used to produce biogas. This allows the emissions from POME discharge to be avoided. Furthermore, the effluent from the POME digestion is returned to field which results in lower external fertilizer requirement. The biogas produced is upgraded and sold as biomethane. This results in an additional co-product that the emissions need to be allocated to. Therefore same amount of mesocarp fibre and shells are used to supply internal energy demand in CHP as in the base case. According to RED the excess fibre and shells produced are defined as residues and therefore no emission should be allocated to these as co-products.

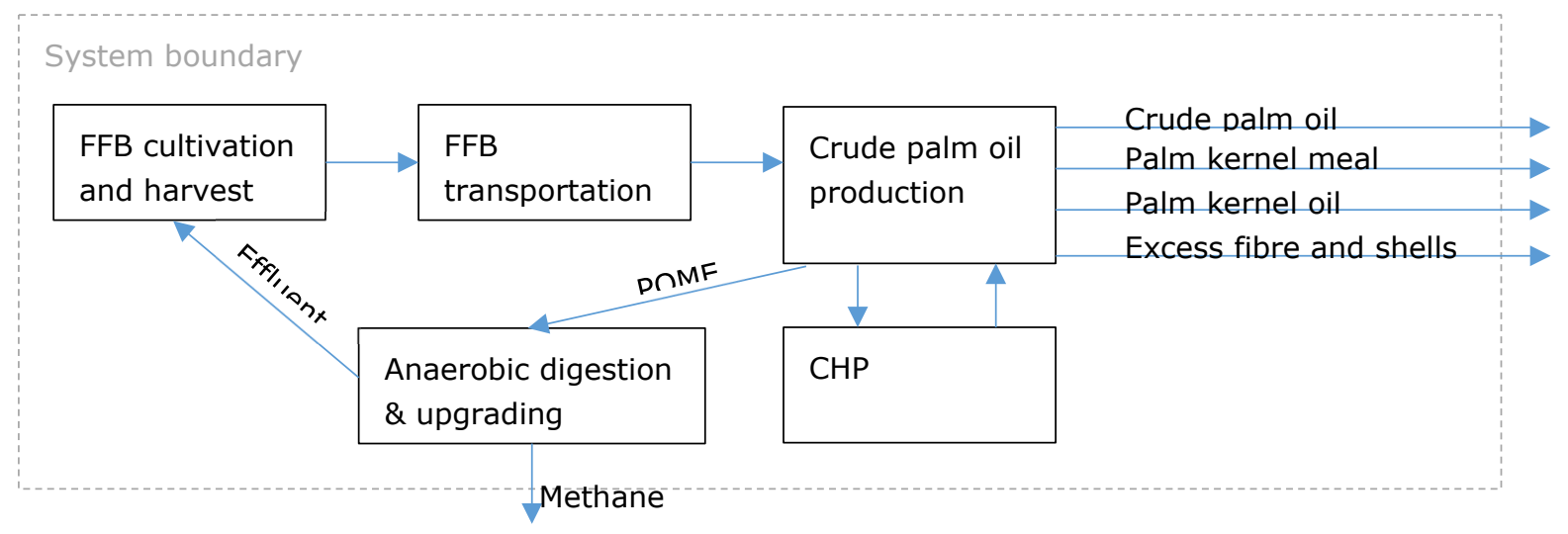

Figure 9 Process flow diagram of Alternative 2: POME conversion into biogas and use of biogas as transportation fuel

The process flow diagram of the case Alternative 3 is seen in Figure 10. As in the base case, the main product is crude palm oil and co-products palm kernel meal and palm kernel oil are produced. The difference with the base case is EFB, which is composted in the base case, is used to produce black pallets by TORWASH ${ }^{\circledR}$. This results in an additional co-product that the emissions need to be allocated to. Furthermore, the effluent from the EFB digestion is returned to field which results in lower external fertilizer requirement. As in the base case POME is discharged. Also, the same amount of mesocarp fibre and shells are used to supply internal energy demand in CHP as in the base case. According to RED the excess fibre and shells produced are defined as residues and therefore no emission should be allocated to these as co-products. 


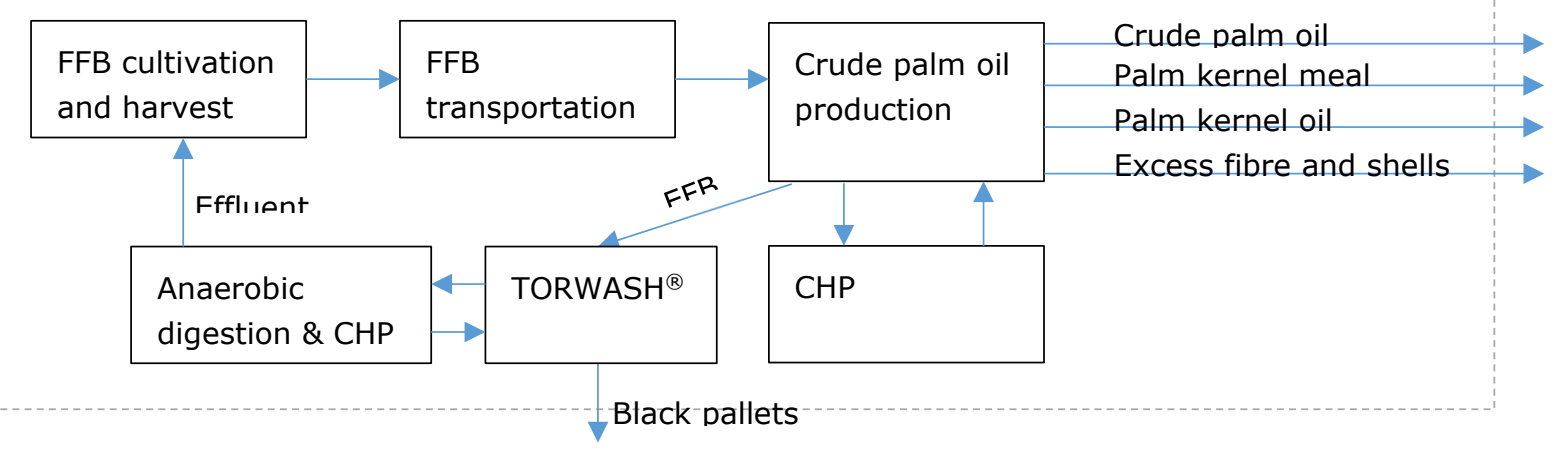

Figure 10 Process flow diagram of Alternative 3: EFB conversion into black pellets (by TORWASH ${ }^{\circ}$ )

The process flow diagram of the case Alternative 4 is seen in Figure 11. As in the base case, the main product is crude palm oil and co-products palm kernel meal and palm kernel oil are produced. The difference with the base case is EFB, which is composted in the base case, is washed and used in CHP to supply internal energy. This results in lower requirement of mesocarp fibre and shells to supply internal energy demand. According to RED the excess fibre and shells produced are defined as residues and therefore no emission should be allocated to these as co-products. The difference in GHG impact is seen in the difference in emissions emitted in the CHP with the fibre and shells being replaced with washed EFB. Furthermore, the effluent from the EFB washing is returned to field which results in lower external fertilizer requirement.

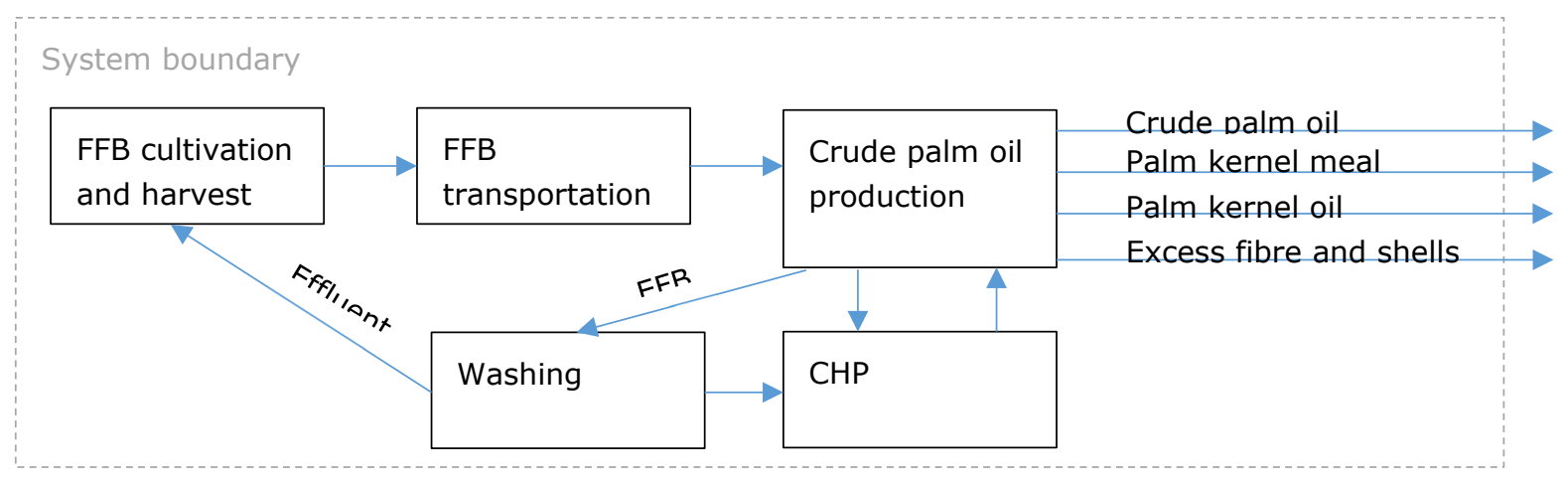

Figure 11 Process flow diagram of Alternative 4: EFB washing and feeding in the existing CHP

Alternative 5 is combination of the Alternatives 1 and 4. With Alternative 1, POME methane emissions are avoided. Additionally, higher amount palm fibre and shells are replaced with POME biogas and washed EFB fed in the CHP. Furthermore, additional nutrients are returned to field resulting in further reduction in external fertilizer requirements.

\subsubsection{Data sources}

The input data to construct inventory tables is obtained from own Palmares report and from technology suppliers for the alternative applications. For default inputs and standard values the values available in the BioGrace tool and most recent JRC reports for biofuels and bioenergy and were used:

- $\quad$ Edwards et al., Definition of input data to assess GHG default emissions from biofuels in EU legislation, v1d, 2019.

- Giuntoli et al., Solid and gaseous bioenergy pathways: input values and GHG emissions, v2, 2017. 


\subsubsection{Inventory Tables}

Cultivation of Fresh Fruit Bunch (FFB)

Table 11 Amounts connected to cultivation of FFB.

\begin{tabular}{|c|c|c|}
\hline & Amount Unit & Comment / Source \\
\hline \multicolumn{3}{|l|}{ Outputs } \\
\hline FFB & $1 \mathrm{~kg}$ & 12.2 ton FFB DM per hectare per year ${ }^{1}$ \\
\hline \multicolumn{3}{|l|}{ Inputs } \\
\hline Synthetic N-fertiliser & $9.17 \mathrm{~g}$ & 1 \\
\hline P2O5-fertiliser & $12.83 \mathrm{~g}$ & $5.6 \mathrm{~g} \mathrm{P} / \mathrm{kg} \mathrm{FFB}^{1}$ \\
\hline K2O-fertiliser & $11.44 \mathrm{~g}$ & $9.5 \mathrm{~g} \mathrm{~K} / \mathrm{kg} \mathrm{FFB}^{1}$ \\
\hline Pesticides & $1.13 \mathrm{~g}$ & $0.05 \mathrm{~g} / \mathrm{MJ} \mathrm{FFB}^{2}$ \\
\hline Field $\mathrm{N}_{2} \mathrm{O}$ emissions & $0.72 \mathrm{~g}$ & $0.02981 \mathrm{~g} / \mathrm{MJ} \mathrm{FFB}^{2}$ \\
\hline Diesel & $0.13 \mathrm{MJ}$ & $0.00537 \mathrm{MJ} / \mathrm{MJ} \mathrm{FFB}^{2}$ \\
\hline
\end{tabular}

1: Visser et al., 2018; 2: Edwards et al., 2019

The fertilizer amounts in the above table are given for the base case. For the alternatives, due to effluent return to field, lower fertilizer input is possible which is shown in the table below.

Table 12 Fertilizer requirements in the alternatives.

\begin{tabular}{|c|c|c|c|c|c|}
\hline & Alt. 1 & Alt. 2 & Alt. 3 & Alt. 4 & Alt. 5 \\
\hline & $\begin{array}{l}\text { POME biogas } \\
\text { CHP }\end{array}$ & POME biomethane & EFB black pellets & EFB CHP & Combi $1 \& 4$ \\
\hline $\mathrm{g} \mathrm{N} / \mathrm{kg}$ FFB & 8.17 & 8.17 & 7.98 & 9.03 & 8.03 \\
\hline $\mathrm{g} \mathrm{P} / \mathrm{kg}$ FFB & 5.35 & 5.35 & 5.39 & 5.48 & 5.23 \\
\hline $\mathrm{g} \mathrm{K} / \mathrm{kg} \mathrm{FFB}$ & 6.65 & 6.65 & 6.06 & 6.28 & 3.43 \\
\hline
\end{tabular}

Transportation of FFB

Table 13 Data with respect to transportation of FFB.

\begin{tabular}{lcc} 
Outputs & Amount Unit & Comment / Source \\
\hline FFB & $1 \mathrm{~kg}$ & $12 \mathrm{t}$ truck using diesel (Edwards et al., 2019) \\
\hline Inputs & & \\
\hline Truck transportation & $0.05 \mathrm{tkm}$ & $50 \mathrm{~km}$ (Edwards et al., 2019) \\
\hline
\end{tabular}

Extraction of oil

Table 14 Inputs and outputs of the mill's oil extraction section in the base case.

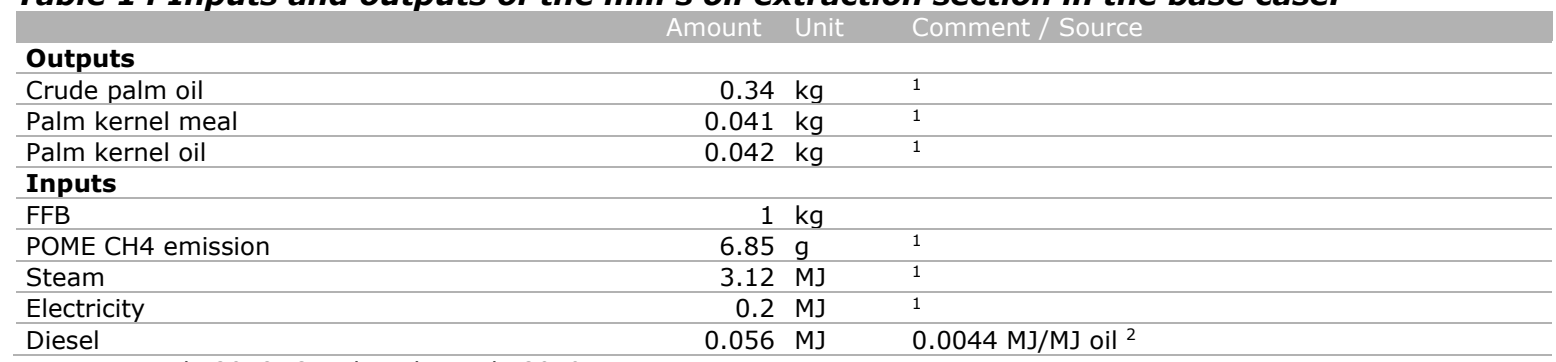

1: Visser et al., 2018; 2: Edwards et al., 2019

The electricity and heat demand in the base case is supplied from Palm kernel shells and mesocarp fibres based CHP. The electrical efficiency of CHP is $4.4 \%$ and thermal efficiency of CHP is $69 \%{ }^{1}$.

In Alternatives 1, 4 and 5 POME and/or EFB are also used to supply internal energy demand. When there is washed EFB co-feed in the CHP in Alternatives 4 and 5, the electrical efficiency of $\mathrm{CHP}$ is $3.6 \%$ and thermal efficiency of $\mathrm{CHP}$ is $57 \%{ }^{1}$. Additional information and calculations on excess shells and fibres in those cases are provided in case study 2.

Standard values are used to convert input numbers into greenhouse gas emissions. For standard values BioGrace-II tool is used. $\mathrm{CH}_{4}$ and $\mathrm{N}_{2} \mathrm{O}$ emissions from washed EFB CHP are not available and are approximated with biogas CHP emissions which is used for the Alternatives 1, 2 and 3. 
Table 15 Allocation in the base case and Alternatives 1, 4 \& 5.

\begin{tabular}{llrrr} 
Products & & & \\
Main product: & Palm oil & 37.00 & $\mathrm{MJ} / \mathrm{kg}$ crude palm oil & $84.5 \%$ \\
\hline Co-product: & Palm kernel meal & 2.23 & $\mathrm{MJ} / \mathrm{kg}$ crude palm oil & $10.4 \%$ \\
\hline Co-product: & Palm kernel oil & 4.57 & $\mathrm{MJ} / \mathrm{kg}$ crude palm oil & $5.1 \%$ \\
\hline Total & & 43.80 & $\mathrm{MJ} / \mathrm{kg}$ crude palm oil & $100 \%$ \\
\hline
\end{tabular}

\subsubsection{Additional processes}

Alternative 2

Biomethane from POME

Table 16 Additional outputs and inputs in alternative 2.

\begin{tabular}{|c|c|c|}
\hline & Amount Unit & Comment / Source \\
\hline \multicolumn{3}{|l|}{ Outputs } \\
\hline Biomethane & $6.1 \mathrm{~g} / \mathrm{kg}$ FFB & Visser et al., 2018 \\
\hline \multicolumn{3}{|l|}{ Inputs } \\
\hline $\begin{array}{l}\text { Biomethane for internal energy supply (digestion }+ \\
\text { upgrading) }\end{array}$ & $0.75 \mathrm{~g} / \mathrm{kg} F \mathrm{FB}$ & Visser et al., 2018 \\
\hline
\end{tabular}

Calculation of allocation:

Table 17 Allocation in Alternative 2.

\begin{tabular}{llrlr} 
Products & & Energy content & Allocation \\
Main product: & Palm oil & 37.00 & $\mathrm{MJ} / \mathrm{kg}$ crude palm oil & $82.9 \%$ \\
\hline Co-product: & Palm kernel meal & 2.23 & $\mathrm{MJ} / \mathrm{kg}$ crude palm oil & $10.2 \%$ \\
\hline Co-product: & Palm kernel oil & 4.57 & $\mathrm{MJ} / \mathrm{kg}$ crude palm oil & $5.0 \%$ \\
\hline Co-product: & Methane & 0.83 & $\mathrm{MJ} / \mathrm{kg}$ crude palm oil & $1.9 \%$ \\
\hline Total & & 44.63 & $\mathrm{MJ} / \mathrm{kg}$ crude palm oil & $100 \%$
\end{tabular}

LHV biomethane: $46.1 \mathrm{MJ} / \mathrm{kg}$ (Giuntoli et al., 2017)

Alternative 3

Black pellets from EFB

Table 18 Additional outputs and inputs in Alternative 3.

\begin{tabular}{lrll} 
Outputs & Amount & Unit & Comment / Source \\
\hline EFB black pellet & $0.198 \mathrm{~kg} / \mathrm{kg} \mathrm{FFB}$ & Visser et al., 2018 \\
\hline Inputs & & & \\
\hline Biogas from EFB effluent for internal energy supply & $0.44 \mathrm{MJ} / \mathrm{kg}$ FFB & Visser et al., 2018 \\
\hline
\end{tabular}

Calculation of allocation:

Table 19 Allocation in Alternative 3.

\begin{tabular}{llrlr}
\hline Products & & Energy content & Allocation \\
Main product: & Palm oil & 37.00 & $\mathrm{MJ} / \mathrm{kg}$ crude palm oil & $66.4 \%$ \\
\hline Co-product: & Palm kernel meal & 2.23 & $\mathrm{MJ} / \mathrm{kg}$ crude palm oil & $8.2 \%$ \\
\hline Co-product: & Palm kernel oil & 4.57 & $\mathrm{MJ} / \mathrm{kg}$ crude palm oil & $4.0 \%$ \\
\hline Co-product: & EFB black pellet & $11.88 \mathrm{MJ} / \mathrm{kg}$ crude palm oil & $21.3 \%$ \\
\hline Total & & 55.68 & $\mathrm{MJ} / \mathrm{kg}$ crude palm oil & $100 \%$
\end{tabular}

LHV black pellet: $20.4 \mathrm{MJ} / \mathrm{kg}$ (Visser et al., 2018) 


\subsection{Impact Assessment Results}

The data above were introduced into the BioGrace tool and yielded the amounts of greenhouse gases emitted, expressed as $\mathrm{g} \mathrm{CO}_{2 \text {,eq }}$ per MJ of palm oil, for the various activities in and around the oil mill. These data are given in the tables below.

\section{Base Case}

\begin{tabular}{|lc|c|}
\hline $\boldsymbol{A} / \mathrm{I}$ results in & $\begin{array}{c}\text { Non- } \\
\text { allocated } \\
\text { results }\end{array}$ & $\begin{array}{c}\text { Total } \\
\text { (allocated } \\
\text { results) }\end{array}$ \\
\hline $\begin{array}{l}\text { Cultivation } \mathbf{e}_{\mathrm{ec}} \\
\text { Cultivation of FFB }\end{array}$ & 24.27 & 20.50 \\
\hline Processing $\mathbf{e}_{\mathbf{p}}$ & & \\
\hline Extraction of oil & 32.04 & 27.06 \\
\hline Transport $e_{\mathrm{td}}$ & & \\
\hline Transport of FFB & 0.84 & 0.71 \\
\hline Totals & $\mathbf{5 7 . 1}$ & $\mathbf{4 8 . 3}$ \\
\hline
\end{tabular}

\begin{tabular}{|c|c|c|}
\hline $\begin{array}{l}\text { All results in } \\
g \mathrm{CO}_{2, \mathrm{eq}} / \mathrm{kg}_{\mathrm{FFB}}\end{array}$ & $\begin{array}{l}\text { Non- } \\
\text { allocated } \\
\text { results }\end{array}$ & $\begin{array}{c}\text { Total } \\
\text { (allocated } \\
\text { results) }\end{array}$ \\
\hline \multicolumn{3}{|l|}{ Cultivation $e_{e c}$} \\
\hline Cultivation of FFB & 305.3 & 257.9 \\
\hline \multicolumn{3}{|l|}{ Processing e ep } \\
\hline Extraction of oil & 403.1 & 340.5 \\
\hline \multicolumn{3}{|l|}{ Transport $e_{t d}$} \\
\hline Transport of FFB & 10.5 & 8.9 \\
\hline Totals & 718.9 & 607.3 \\
\hline
\end{tabular}

LHV of oil is $37 \mathrm{MJ} / \mathrm{kg}, 0.34 \mathrm{~kg}$ oil $/ \mathrm{kg}$ FFB DM

\begin{tabular}{|l|}
\hline Allocation factors \\
\hline Extraction of oil \\
$84.5 \%$ to Palm oil \\
$10.4 \%$ to Palm kernel oil \\
$5.1 \%$ to Palm kernel meal \\
\hline
\end{tabular}


Alternative 1: POME conversion into biogas and use of biogas in an existing CHP.

\begin{tabular}{|lc|c|}
\hline $\mathbf{A l l}$ results in & $\begin{array}{c}\text { Non- } \\
\text { allocated } \\
\mathbf{g ~ C O}_{2, \text { eq }} / \mathbf{M J}_{\text {PO }}\end{array}$ & $\begin{array}{c}\text { Total } \\
\text { (allocated results) }\end{array}$ \\
\hline $\begin{array}{l}\text { Cultivation } \mathbf{e}_{\mathrm{ec}} \\
\text { Cultivation of FFB }\end{array}$ & 23.68 & 20.00 \\
\hline $\begin{array}{l}\text { Processing } \mathrm{e}_{\mathrm{p}} \\
\text { Extraction of oil }\end{array}$ & 12.31 & 10.40 \\
\hline Transport $\mathrm{e}_{\mathrm{td}}$ & & \\
\hline Transport of FFB & 0.84 & 0.71 \\
\hline Totals & $\mathbf{3 6 . 8}$ & $\mathbf{3 1 . 1}$ \\
\hline
\end{tabular}

\begin{tabular}{|lc|c|}
\hline $\boldsymbol{A} / \mathrm{l}$ results in & $\begin{array}{c}\text { Non- } \\
\text { allocated } \\
\text { results }\end{array}$ & $\begin{array}{c}\text { Total } \\
\text { (allocated } \\
\text { results) }\end{array}$ \\
\hline $\begin{array}{l}\text { Cultivation } \mathbf{e}_{\mathbf{e c}} \\
\text { Cultivation of FFB }\end{array}$ & 297.9 & 251.7 \\
\hline Processing ep & 154.8 & 130.8 \\
\hline Extraction of oil & 10.5 & \\
\hline Transport $\mathbf{e}_{\mathrm{td}}$ & $\mathbf{4 6 3 . 3}$ & $\mathbf{3 9 1 . 4}$ \\
\hline Transport of FFB & & \\
\hline Totals & & \\
\hline
\end{tabular}

\begin{tabular}{|l|}
\hline Allocation factors \\
\hline Extraction of oil \\
$84.5 \%$ to Palm oil \\
$10.4 \%$ to Palm kernel oil \\
$5.1 \%$ to Palm kernel meal \\
\hline
\end{tabular}


Alternative 2: POME conversion into biogas and use of biogas as transportation fuel.

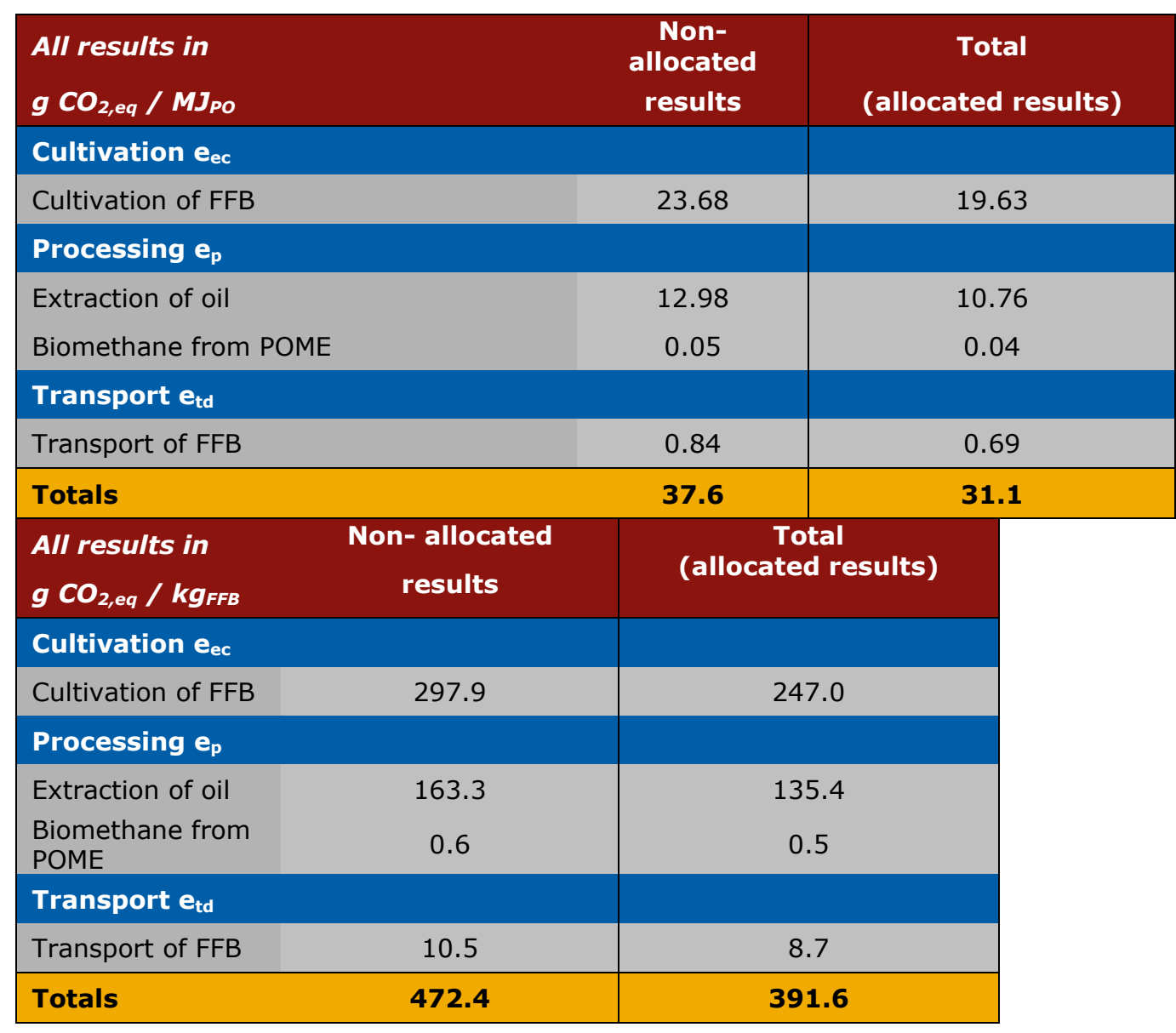

\begin{tabular}{|l|}
\hline Allocation factors \\
\hline Extraction of oil \\
$82.9 \%$ to Palm oil \\
$10.2 \%$ to Palm kernel oil \\
$5.0 \%$ to Palm kernel meal \\
$1.9 \%$ to Biomethane \\
\hline
\end{tabular}

Alternative 3: EFB conversion into black pellets (by TORWASH ${ }^{\circledR}$ ).

\begin{tabular}{|c|c|c|}
\hline $\begin{array}{l}\text { All results in } \\
g \mathrm{CO}_{2, \mathrm{eq}} / \mathrm{MJ}_{\mathrm{PO}}\end{array}$ & $\begin{array}{l}\text { Non- } \\
\text { allocated } \\
\text { results }\end{array}$ & $\begin{array}{c}\text { Total } \\
\text { (allocated results) }\end{array}$ \\
\hline \multicolumn{3}{|l|}{ Cultivation $e_{e c}$} \\
\hline Cultivation of FFB & 23.59 & 15.67 \\
\hline \multicolumn{3}{|l|}{ Processing $e_{p}$} \\
\hline Extraction of oil & 32.04 & 21.29 \\
\hline Biogas CHP for TORWASH ${ }^{\circledR}$ & 0.40 & 0.27 \\
\hline \multicolumn{3}{|l|}{ Transport $e_{t d}$} \\
\hline Transport of FFB & 0.84 & 0.56 \\
\hline Totals & 56.9 & 37.8 \\
\hline
\end{tabular}




\begin{tabular}{|c|c|c|}
\hline $\begin{array}{l}\text { All results in } \\
\mathrm{g} \mathrm{CO}_{2, \mathrm{eq}} / \mathrm{kg}_{\mathrm{FFB}}\end{array}$ & $\begin{array}{l}\text { Non- allocated } \\
\text { results }\end{array}$ & $\begin{array}{c}\text { Total } \\
\text { (allocated results) }\end{array}$ \\
\hline \multicolumn{3}{|l|}{ Cultivation $e_{e c}$} \\
\hline Cultivation of FFB & 296.7 & 197.2 \\
\hline \multicolumn{3}{|l|}{ Processing $e_{p}$} \\
\hline $\begin{array}{l}\text { Extraction of oil } \\
\text { Biogas CHP for } \\
\text { TORWASH }^{\circledR}\end{array}$ & $\begin{array}{c}403.1 \\
5.0\end{array}$ & $\begin{array}{c}267.8 \\
3.3\end{array}$ \\
\hline \multicolumn{3}{|l|}{ Transport $e_{t d}$} \\
\hline Transport of FFB & 10.5 & 7.0 \\
\hline Totals & 715.3 & 475.3 \\
\hline \multicolumn{3}{|l|}{ Allocation factors } \\
\hline \multicolumn{3}{|l|}{ Extraction of oil } \\
\hline \multicolumn{3}{|c|}{$66.4 \%$ to Palm oil } \\
\hline \multicolumn{3}{|c|}{$8.2 \%$ to Palm kernel oil } \\
\hline \multicolumn{3}{|c|}{$4.0 \%$ to Palm kernel meal } \\
\hline \multicolumn{3}{|c|}{$21.3 \%$ to EFB black pellet } \\
\hline
\end{tabular}

Alternative 4: EFB washing and feeding in the existing CHP.

\begin{tabular}{|c|c|c|}
\hline $\begin{array}{l}\text { All results in } \\
g \mathrm{CO}_{2, \mathrm{eq}} / \mathrm{MJ}_{\mathrm{PO}}\end{array}$ & $\begin{array}{l}\text { Non- } \\
\text { allocated } \\
\text { results }\end{array}$ & $\begin{array}{c}\text { Total } \\
\text { (allocated results) }\end{array}$ \\
\hline \multicolumn{3}{|l|}{ Cultivation $e_{e c}$} \\
\hline Cultivation of FFB & 24.00 & 20.27 \\
\hline \multicolumn{3}{|l|}{ Processing $\mathbf{e}_{\mathrm{p}}$} \\
\hline Extraction of oil & 26.38 & 22.28 \\
\hline \multicolumn{3}{|l|}{ Transport $\mathbf{e}_{t d}$} \\
\hline Transport of FFB & 0.84 & 0.71 \\
\hline Totals & 51.2 & 43.3 \\
\hline
\end{tabular}

\begin{tabular}{|lc|c|}
\hline All results in & $\begin{array}{c}\text { Non- } \\
\text { allocated } \\
\text { results }\end{array}$ & $\begin{array}{c}\text { Total } \\
\text { (allocated } \\
\text { results) }\end{array}$ \\
\hline $\begin{array}{l}\text { Cultivation } \mathbf{e}_{\mathrm{ec}} \\
\text { Cultivation of FFB }\end{array}$ & 301.9 & 255.0 \\
\hline Processing $\mathbf{e}_{\mathrm{p}}$ & & \\
\hline Extraction of oil & 331.8 & 280.3 \\
\hline Transport etd & & \\
\hline Transport of FFB & 10.5 & 8.9 \\
\hline Totals & $\mathbf{6 4 4 . 3}$ & $\mathbf{5 4 4 . 2}$ \\
\hline
\end{tabular}




\begin{tabular}{|l|}
\hline Allocation factors \\
\hline Extraction of oil \\
$84.5 \%$ to Palm oil \\
$10.4 \%$ to Palm kernel oil \\
$5.1 \%$ to Palm kernel meal \\
\hline
\end{tabular}

Alternative 5: combination of using biogas from POME and washed EFB in the existing CHP.

\begin{tabular}{|c|c|c|}
\hline $\begin{array}{l}\text { All results in } \\
\mathrm{g} \mathrm{CO}_{2, \text { eq }} / \mathrm{MJ}_{\mathrm{PVO}}\end{array}$ & $\begin{array}{c}\text { Non- } \\
\text { allocated } \\
\text { results }\end{array}$ & $\begin{array}{c}\text { Total } \\
\text { (allocated results) }\end{array}$ \\
\hline \multicolumn{3}{|l|}{ Cultivation $e_{e c}$} \\
\hline Cultivation of FFB & 23.41 & 19.77 \\
\hline \multicolumn{3}{|l|}{ Processing $e_{p}$} \\
\hline Extraction of oil & 6.60 & 5.57 \\
\hline \multicolumn{3}{|l|}{ Transport etd } \\
\hline Transport of FFB & 0.84 & 0.71 \\
\hline Totals & 30.8 & 26.1 \\
\hline
\end{tabular}

\begin{tabular}{|lc|c|}
\hline $\boldsymbol{A} / \mathrm{I}$ results in & $\begin{array}{c}\text { Non- } \\
\text { allocated } \\
\text { results }\end{array}$ & $\begin{array}{c}\text { Total } \\
\text { (allocated } \\
\text { results) }\end{array}$ \\
\hline $\begin{array}{l}\text { Cultivation } \mathbf{e}_{\mathrm{ec}} \\
\text { Cultivation of FFB }\end{array}$ & 294.5 & 248.8 \\
\hline Processing $\mathbf{e}_{\mathbf{p}}$ & & \\
\hline Extraction of oil & 83.0 & 70.1 \\
\hline Transport etd & & \\
\hline Transport of FFB & 10.5 & 8.9 \\
\hline Totals & $\mathbf{3 8 8 . 0}$ & $\mathbf{3 2 7 . 8}$ \\
\hline
\end{tabular}

\begin{tabular}{|l|}
\hline Allocation factors \\
\hline Extraction of oil \\
$84.5 \%$ to Palm oil \\
$10.4 \%$ to Palm kernel oil \\
$5.1 \% \quad$ to Palm kernel meal \\
\hline
\end{tabular}


The data can be summarized and expressed as g CO2,eq/MJ palm oil and as $\mathrm{kg} \mathrm{CO2,eq/ton} \mathrm{FFB} \mathrm{DM.} \mathrm{The}$ latter connects to the other sections in this report in which FFB dry matter is taken as the base to express mass flows, costs and benefits.

Table 20 Summary of environmental impact data expressed per MJ palm oil or per ton FFB DM.

\begin{tabular}{|c|c|c|c|c|c|c|}
\hline & Base Case & $\begin{array}{l}\text { Alt. 1: } \\
\text { POME } \\
\text { biogas CHP }\end{array}$ & $\begin{array}{l}\text { Alt. 2: POME } \\
\text { biomethane }\end{array}$ & $\begin{array}{l}\text { Alt. 3: EFB } \\
\text { black pellet }\end{array}$ & $\begin{array}{l}\text { Alt. 4: EFB } \\
\text { CHP }\end{array}$ & $\begin{array}{l}\text { Alt 5: } \\
\text { POME } \\
\text { biogas }+ \\
\text { EFB CHP }\end{array}$ \\
\hline \multirow{3}{*}{$\begin{array}{r}\text { Non allocated GHG results, } \\
\text { gCO2,eq/MJPO } \\
\text { Allocated } G H G \text { results, } \\
\text { gCO2,eq/MJPO }\end{array}$} & 57.15 & 36.83 & 37.55 & 56.86 & 51.22 & 30.84 \\
\hline & 48.27 & 31.11 & 31.13 & 37.78 & 43.26 & 26.05 \\
\hline & Base Case & $\begin{array}{l}\text { Alt. 1: } \\
\text { POME } \\
\text { biogas CHP }\end{array}$ & $\begin{array}{l}\text { Alt. 2: POME } \\
\text { biomethane }\end{array}$ & $\begin{array}{l}\text { Alt. 3: EFB } \\
\text { black pellet }\end{array}$ & $\begin{array}{l}\text { Alt. 4: EFB } \\
\text { CHP }\end{array}$ & $\begin{array}{l}\text { Alt 5: } \\
\text { POME } \\
\text { biogas }+ \\
\text { EFB CHP }\end{array}$ \\
\hline \multirow{2}{*}{$\begin{array}{r}\text { Non allocated GHG results, } \\
\text { kgCO2,eq/ton FFB DM } \\
\text { Allocated GHG results, } \\
\text { kgCO2,eq/ton FFB DM }\end{array}$} & 718.9 & 463.3 & 472.4 & 715.3 & 644.3 & 388.0 \\
\hline & 607.3 & 391.4 & 391.6 & 475.3 & 544.2 & 327.8 \\
\hline
\end{tabular}

The impact data can be broken down over the various emission sources and the expression can be without allocation (Figure 12, Table 21) or with allocation (Figure 13, Table 22).

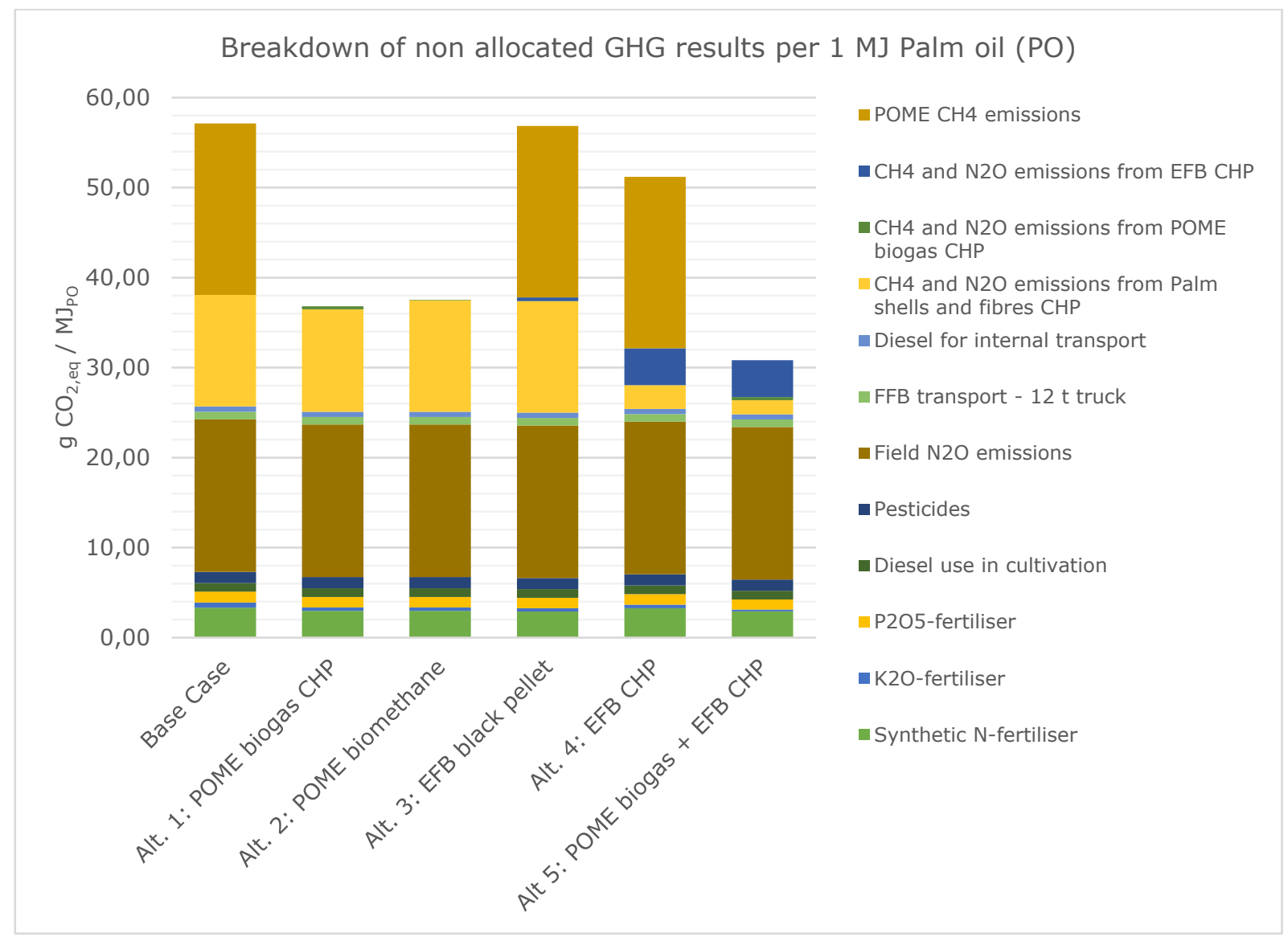

Figure 12 Breakdown of the results and comparative assessment without allocation 


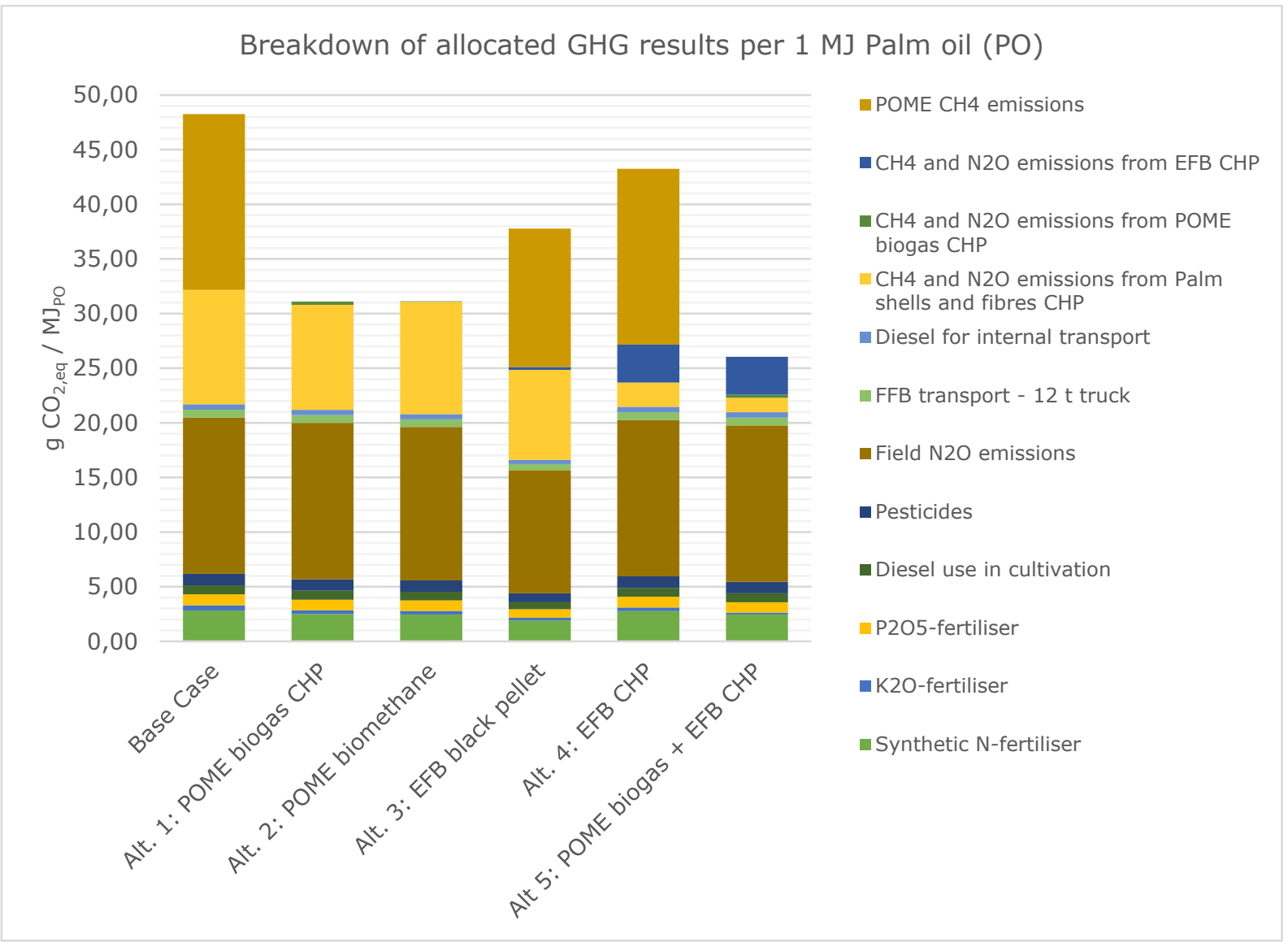

Figure 13 Breakdown of the results and comparative assessment with allocation

Table 21 Non-allocated GHG results breakdown per MJ Palm oil, in g $\mathrm{CO}_{2, e q} / \mathrm{MJ}_{P O}$.

\begin{tabular}{|c|c|c|c|c|c|c|}
\hline & Base Case & $\begin{array}{l}\text { Alt. 1: } \\
\text { POME } \\
\text { biogas CHP }\end{array}$ & $\begin{array}{l}\text { Alt. 2: POME } \\
\text { biomethane }\end{array}$ & $\begin{array}{l}\text { Alt. 3: EFB } \\
\text { black pellet }\end{array}$ & $\begin{array}{l}\text { Alt. 4: EFB } \\
\text { CHP }\end{array}$ & $\begin{array}{l}\text { Alt 5: } \\
\text { POME } \\
\text { biogas + } \\
\text { EFB CHP }\end{array}$ \\
\hline Synthetic $N$-fertiliser & 3.33 & 2.97 & 2.97 & 2.90 & 3.28 & 2.92 \\
\hline K2O-fertiliser & 0.58 & 0.40 & 0.40 & 0.37 & 0.38 & 0.21 \\
\hline P2O5-fertiliser & 1.20 & 1.15 & 1.15 & 1.15 & 1.17 & 1.12 \\
\hline Diesel use in cultivation & 0.96 & 0.96 & 0.96 & 0.96 & 0.96 & 0.96 \\
\hline Pesticides & 1.24 & 1.24 & 1.24 & 1.24 & 1.24 & 1.24 \\
\hline Field $\mathrm{N} 2 \mathrm{O}$ emissions & 16.95 & 16.95 & 16.95 & 16.95 & 16.95 & 16.95 \\
\hline FFB transport - 12 t truck & 0.84 & 0.84 & 0.84 & 0.84 & 0.84 & 0.84 \\
\hline Diesel for internal transport & 0.58 & 0.58 & 0.58 & 0.58 & 0.58 & 0.58 \\
\hline Emissions from Palm shells and fibres CHP & 12.40 & 11.38 & 12.40 & 12.40 & 2.63 & 1.56 \\
\hline Emissions from POME biogas $C H P$ & 0.00 & 0.35 & 0.05 & 0.00 & 0.00 & 0.35 \\
\hline Emissions from EFB CHP & 0.00 & 0.00 & 0.00 & 0.40 & 4.10 & 4.10 \\
\hline POME CH4 emissions & 19.06 & 0.00 & 0.00 & 19.06 & 19.06 & 0.00 \\
\hline Total & 57.15 & 36.83 & 37.55 & 56.86 & 51.22 & 30.84 \\
\hline
\end{tabular}


Table 22 Allocated GHG results breakdown per MJ Palm oil, in g $\mathrm{CO}_{2, \mathrm{eq}} / \mathrm{MJ}_{P O}$.

\begin{tabular}{|c|c|c|c|c|c|c|}
\hline & Base Case & $\begin{array}{l}\text { Alt. 1: } \\
\text { POME } \\
\text { biogas CHP }\end{array}$ & $\begin{array}{l}\text { Alt. 2: POME } \\
\text { biomethane }\end{array}$ & $\begin{array}{l}\text { Alt. 3: EFB } \\
\text { black pellet }\end{array}$ & $\begin{array}{l}\text { Alt. 4: EFB } \\
\text { CHP }\end{array}$ & $\begin{array}{l}\text { Alt 5: } \\
\text { POME } \\
\text { biogas + } \\
\text { EFB CHP }\end{array}$ \\
\hline Synthetic $N$-fertiliser & 2.81 & 2.51 & 2.46 & 1.93 & 2.77 & 2.46 \\
\hline K2O-fertiliser & 0.49 & 0.34 & 0.34 & 0.25 & 0.32 & 0.18 \\
\hline P205-fertiliser & 1.01 & 0.97 & 0.95 & 0.77 & 0.99 & 0.95 \\
\hline Diesel use in cultivation & 0.81 & 0.81 & 0.80 & 0.64 & 0.81 & 0.81 \\
\hline Pesticides & 1.05 & 1.05 & 1.03 & 0.83 & 1.05 & 1.05 \\
\hline Field $\mathrm{N} 2 \mathrm{O}$ emissions & 14.32 & 14.32 & 14.05 & 11.26 & 14.32 & 14.32 \\
\hline FFB transport $-12 t$ truck & 0.71 & 0.71 & 0.69 & 0.56 & 0.71 & 0.71 \\
\hline Diesel for internal transport & 0.49 & 0.49 & 0.48 & 0.39 & 0.49 & 0.49 \\
\hline Emissions from Palm shells and fibres $\mathrm{CHP}$ & 10.47 & 9.61 & 10.28 & 8.24 & 2.22 & 1.32 \\
\hline Emissions from POME biogas $C H P$ & 0.00 & 0.29 & 0.04 & 0.00 & 0.00 & 0.29 \\
\hline Emissions from EFB CHP & 0.00 & 0.00 & 0.00 & 0.27 & 3.47 & 3.47 \\
\hline POME CH4 emissions & 16.10 & 0.00 & 0.00 & 12.66 & 16.10 & 0.00 \\
\hline Total & 48.27 & 31.11 & 31.13 & $\mathbf{3 7 . 7 8}$ & 43.26 & 26.05 \\
\hline
\end{tabular}

\subsection{Interpretation of the results}

In Alternatives 1 and 2, the main difference with the base case comes from the avoided POME methane emissions. These two cases are seen to have very similar environmental performance. This means the biogas produced from POME can either be used in CHP to supply internal energy which enables savings in emissions resulting from palm kernel shells and fibres that are replaced. Or alternatively upgraded and sold as methane which results in lower allocation of emissions to the main product of palm oil.

In Alternatives 3 and 4, the POME methane emissions are not avoided and therefore seen to have worse environmental performance than Alternatives 1 and 2. The TORWASH ${ }^{\circledR}$ process used to produce black pellets in Alternative 3 is seen to be the better choice in utilising EFB. This is due to the significant (18\%) reduction in the allocation factor of palm oil with the EFB black pellets produced as co-products.

Alternative 5, is seen to have the best environmental performance among the alternatives combining the benefits gained in Alternatives 1 and 4 from avoiding POME methane emissions and utilising POME biogas and EFB in CHP, replacing palm shells and kernel based CHP emissions. 


\subsection{Case Studies}

\subsubsection{EFB CHP emissions - approximated with Palm shells and fibres}

Due to the unavailability of information regarding $\mathrm{CH} 4$ and $\mathrm{N} 2 \mathrm{O}$ emissions from washed EFB, which is required in the assessment of Alternatives 4 and 5, it was approximated with biogas in the results shown above. In order to show influence of approximating with Palm shells and fibres the following calculations were made. The summary is shown in Figure 14 and Table 23.

Alternative 4: EFB washing and feeding in the existing CHP (with emissions approximated with palm shells and fibres).

\begin{tabular}{|c|c|c|}
\hline $\begin{array}{l}\text { All results in } \\
\mathrm{g} \mathrm{CO}_{2, \mathrm{eq}} / \mathrm{MJ}_{\mathrm{PO}}\end{array}$ & $\begin{array}{l}\text { Non- } \\
\text { allocated } \\
\text { results }\end{array}$ & $\begin{array}{c}\text { Total } \\
\text { (allocated results) }\end{array}$ \\
\hline \multicolumn{3}{|l|}{ Cultivation eec } \\
\hline Cultivation of FFB & 24.00 & 20.27 \\
\hline \multicolumn{3}{|l|}{ Processing $e_{p}$} \\
\hline Extraction of oil & 34.65 & 29.27 \\
\hline \multicolumn{3}{|l|}{ Transport $e_{t d}$} \\
\hline Transport of FFB & 0.84 & 0.71 \\
\hline Totals & 59.5 & 50.3 \\
\hline
\end{tabular}

Alternative 5: combination of using biogas from POME and washed EFB in the existing CHP (with emissions approximated with palm shells and fibres).

\begin{tabular}{|c|c|c|}
\hline $\begin{array}{l}\text { All results in } \\
g \mathrm{CO}_{2, \mathrm{eq}} / \mathrm{MJ} \mathrm{Jvo}\end{array}$ & $\begin{array}{l}\text { Non- } \\
\text { allocated } \\
\text { results }\end{array}$ & $\begin{array}{c}\text { Total } \\
\text { (allocated results) }\end{array}$ \\
\hline \multicolumn{3}{|l|}{ Cultivation ecc } \\
\hline Cultivation of FFB & 23.41 & 19.77 \\
\hline \multicolumn{3}{|l|}{ Processing $\mathbf{e}_{\mathbf{p}}$} \\
\hline Extraction of oil & 14.87 & 12.56 \\
\hline \multicolumn{3}{|l|}{ Transport etd } \\
\hline Transport of FFB & 0.84 & 0.71 \\
\hline Totals & 39.1 & 33.0 \\
\hline
\end{tabular}




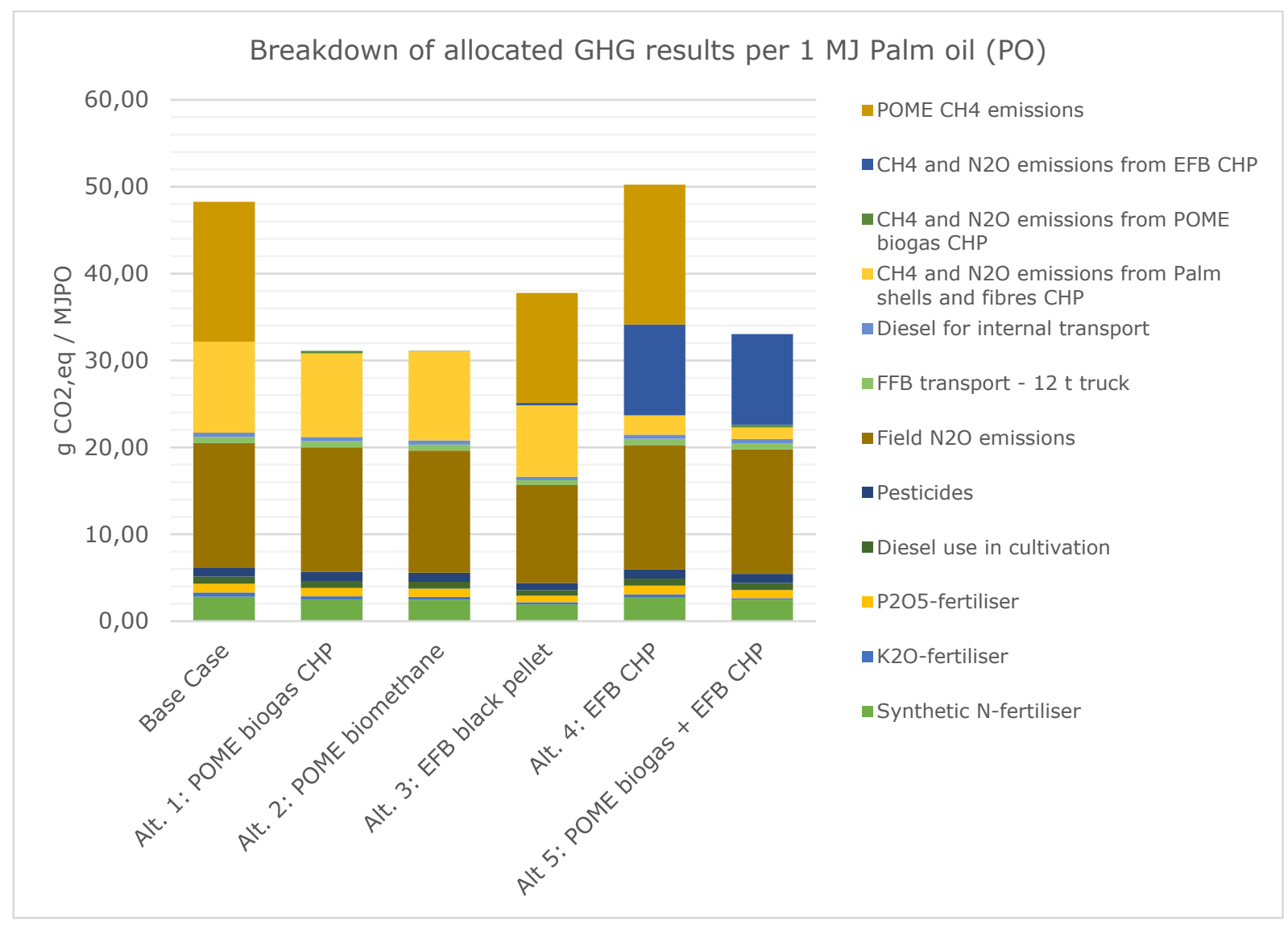

Figure 14 Breakdown of allocated GHG results - with EFB CHP emissions approximated with the emissions of Palm shells and fibres $\mathrm{CHP}$

Table 23 Comparative assessment of overall GHG results - with EFB CHP emissions approximated with the emissions of Palm shells and fibres CHP.

\begin{tabular}{|c|c|c|c|c|c|c|}
\hline & Base Case & $\begin{array}{l}\text { Alt. 1: } \\
\text { POME } \\
\text { biogas CHP }\end{array}$ & $\begin{array}{l}\text { Alt. 2: POME } \\
\text { biomethane }\end{array}$ & $\begin{array}{l}\text { Alt. 3: EFB } \\
\text { black pellet }\end{array}$ & $\begin{array}{l}\text { Alt. 4: EFB } \\
\text { CHP }\end{array}$ & $\begin{array}{l}\text { Alt 5: } \\
\text { POME } \\
\text { biogas + } \\
\text { EFB CHP }\end{array}$ \\
\hline \multirow{3}{*}{$\begin{array}{r}\text { Non allocated GHG results, } \\
\text { gCO2,eq/MJPO } \\
\text { Allocated } G H G \text { results, } \\
g C O 2, e q / M J P O\end{array}$} & 57.15 & 36.83 & 37.55 & 56.86 & 59.49 & 39.11 \\
\hline & 48.27 & 31.11 & 31.13 & 37.78 & 50.25 & 33.04 \\
\hline & Base Case & $\begin{array}{l}\text { Alt. 1: } \\
\text { POME } \\
\text { biogas CHP }\end{array}$ & $\begin{array}{l}\text { Alt. 2: POME } \\
\text { biomethane }\end{array}$ & $\begin{array}{l}\text { Alt. 3: EFB } \\
\text { black pellet }\end{array}$ & $\begin{array}{l}\text { Alt. 4: EFB } \\
\text { CHP }\end{array}$ & $\begin{array}{l}\text { Alt 5: } \\
\text { POME } \\
\text { biogas + } \\
\text { EFB CHP }\end{array}$ \\
\hline $\begin{array}{r}\text { Non allocated GHG results, } \\
g C O 2, e q / \mathrm{kg} \mathrm{FFB}\end{array}$ & 718.9 & 463.3 & 472.4 & 715.3 & 748.3 & 492.0 \\
\hline $\begin{array}{r}\text { Allocated GHG results, } \\
g C O 2, e q / \mathrm{kg} \mathrm{FFB}\end{array}$ & 607.3 & 391.4 & 391.6 & 475.3 & 632.1 & 415.6 \\
\hline
\end{tabular}

\subsubsection{Interpretation}

Due to lower energy efficiency of washed EFB CHP, higher amount of CHP input is required in Alt. 4 resulting in higher emissions than the base case, when same emissions per MJ is taken for EFB CHP as with the Palm shells and fibres CHP. Because of this, Alternative 5 is seen not better than Alternatives 2 and 3 , which was the case when lower EFB CHP emissions were taken in the base results. 


\subsection{Credit for the excess palm shells and fibres}

According to RED the excess fibre and shells produced are defined as residues and therefore no emission should be allocated to these as co-products. They are used in supplying the heat and electricity demand of the process. The use of an internal CHP to produce process heat and electricity (and excess heat or electricity) requires emissions to be properly allocated between the heat and electricity produced. This allocation is done based on exergy following the RED methodology.

However, according to this methodology no credits are given for the excess residues of Palm kernel shells and mesocarp fibres. However, these have energetic value and are sold to be used as solid biomass fuel for energy purposes. Accordingly, an additional case study was conducted to analyse the added environmental benefits if the energetic value of these excess residues were considered as credits.

The sizing of the CHP should be done to supply the minimum necessary amount of heat needed in the processes. However, to determine the generated excess electricity and heat from the different alternatives same amount of Palm kernel shells and mesocarp fibres input in base case was considered in all alternatives. Accordingly the surplus electricity and heat was calculated.

The greenhouse gas intensity of excess useful heat or excess electricity is the same as the greenhouse gas intensity of heat or electricity delivered to the biomass fuel production process and is determined by using exergy to allocate the emissions between the different CHP outputs:

- $\quad$ Fraction CHP emissions to heat for internal use (into calculation)

- Fraction CHP emissions to electricity for internal use (into calculation)

- Fraction CHP emissions to surplus electricity (outside calculation)

- $\quad$ Fraction CHP emissions to surplus heat (outside calculation)

With this allocation, the emissions created from the surplus electricity and heat generated in the alternatives from the excess residues were not taken into calculations.

An example for this calculation is shown below for Alternative 1:

Table 24 Example of calculations concerning the existing oil mill CHP.

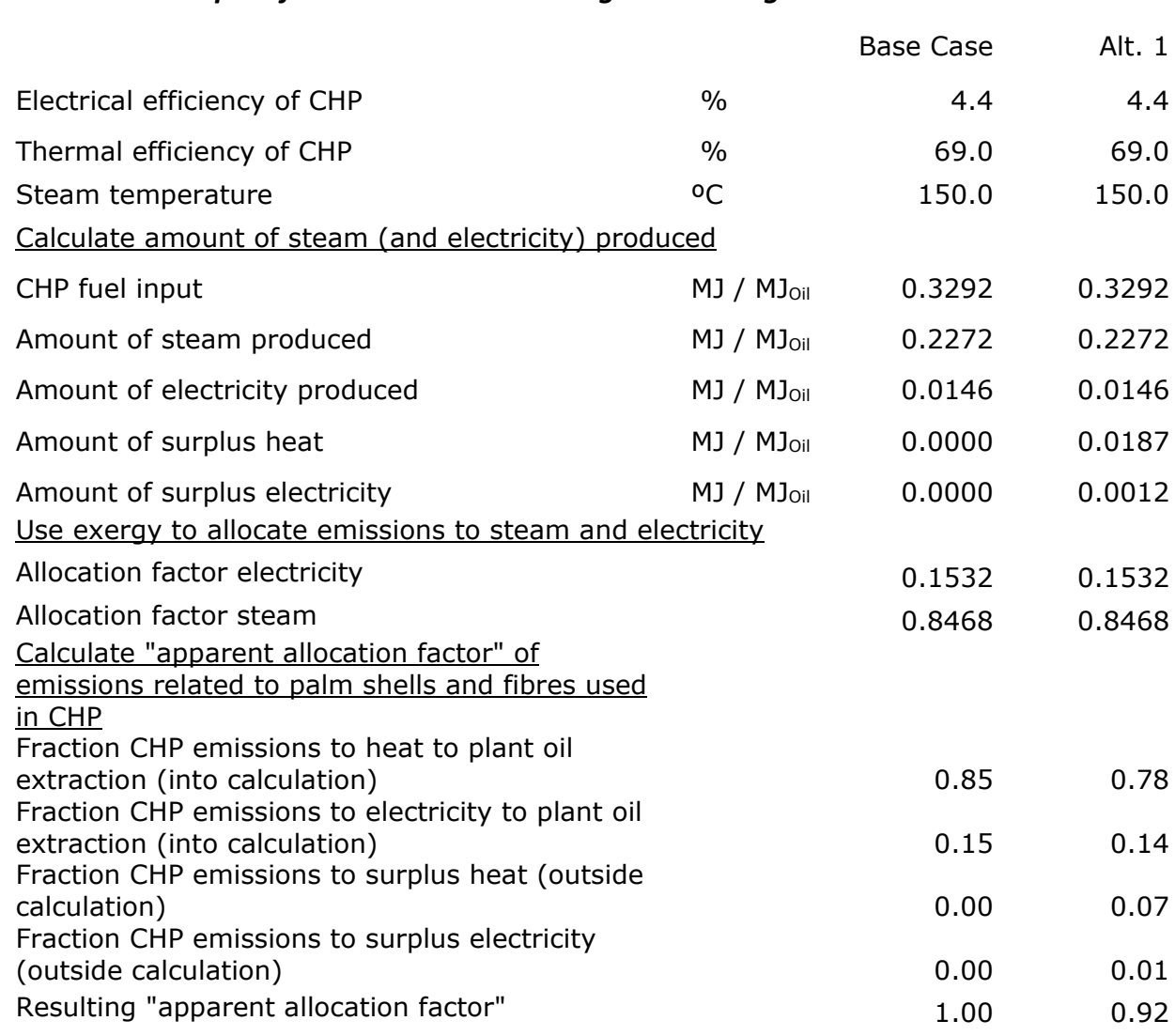


Table 24 show the results from calculations using BioGrace (not visible in this report). In case 1 biogas is fed into $\mathrm{CHP}$, the values 0.0187 and 0.0012 correspond to heat and electricity that can be produced from $0.027 \mathrm{MJ}$ biogas/MJ palm oil with 69\% thermal, 4\% electric efficiency (CHP efficiencies of baseline). Accordingly, this much amount of heat and electricity that can be produced from palm kernel shells and fibres is now excess. In case 4 there is EFB CHP: 0.1789 and 0.0115 correspond to heat and electricity that can be produced from $0.33 \mathrm{MJ}$ EFB/MJ palm oil, 54.5\% thermal, 3.5\% electrical efficiency. These numbers are introduced in Table 25.

Table 25 The Surplus Heat and Electricity of the Alternatives.

\begin{tabular}{|c|c|c|c|c|c|}
\hline & Alt. 1 & Alt. 2 & Alt. 3 & Alt. 4 & Alt. 5 \\
\hline & $\begin{array}{l}\text { POME biogas } \\
\text { CHP }\end{array}$ & $\begin{array}{l}\text { POME } \\
\text { biomethane }\end{array}$ & $\begin{array}{l}\text { EFB black } \\
\text { pellets }\end{array}$ & EFB CHP & Combi $1 \& 4$ \\
\hline Surplus heat, $\mathrm{MJ} / \mathrm{MJ}_{\mathrm{Oil}}$ & 0.0187 & 0 & 0 & 0.1789 & 0.1986 \\
\hline Surplus electricity, $\mathrm{MJ} / \mathrm{MJ} \mathrm{O}_{\mathrm{Oil}}$ & 0.0012 & 0 & 0 & 0.0115 & 0.0127 \\
\hline
\end{tabular}

To calculate credits for surplus heat and electricity, marginal heat and electricity supply is considered. It was considered for simplicity that these excess residues are exported to Europe for heat and electricity supply. For marginal supply of electricity, EU mix medium voltage grid electricity is considered. For marginal supply, heat from natural gas is considered. The marginal heat mix is considered to consist of approximately $70 \%$ heat from combined heat and power plants and $30 \%$ heat from boiler. For the calculation of steam from NG boiler and CHP, JRC report process data is used. The unit emissions for these marginal supplies are acquired from JRC report:

Table 26 Emissions connected to various energy sources.

\begin{tabular}{lr} 
Energy source & Emission \\
EU Mix, medium voltage (marginal & $141.1 \mathrm{~g} \mathrm{CO}_{2, \mathrm{eq}} / \mathrm{MJ} \mathrm{el}_{\mathrm{el}}$ \\
electricity) & $66.0 \mathrm{~g} \mathrm{CO}_{2, \mathrm{eq}} / \mathrm{MJ} \mathrm{J}_{\mathrm{NG}}$ \\
\hline Natural gas & $76.5 \mathrm{~g} \mathrm{CO}_{2, \mathrm{eq}} / \mathrm{MJ}_{\mathrm{h}}$ \\
\hline Steam from natural gas, boiler & $49.1 \mathrm{~g} \mathrm{CO}_{2, \mathrm{eq}} / \mathrm{MJ}$ \\
\hline Steam from natural gas, CHP & $57.3 \mathrm{~g} \mathrm{CO}_{2, \mathrm{eq}} / \mathrm{MJ}$ \\
\hline
\end{tabular}

The emissions - $\mathrm{CH} 4$ and N2O emissions from Palm shells and fibres CHP - that are allocated to surplus heat and electricity are given in Table 27. The data in Table 27 are calculated from Table 24 using the Biograce model (not visible in this report).

Table 27 GHG (CH4 and N20) emissions from Palm shells and fibres CHP.

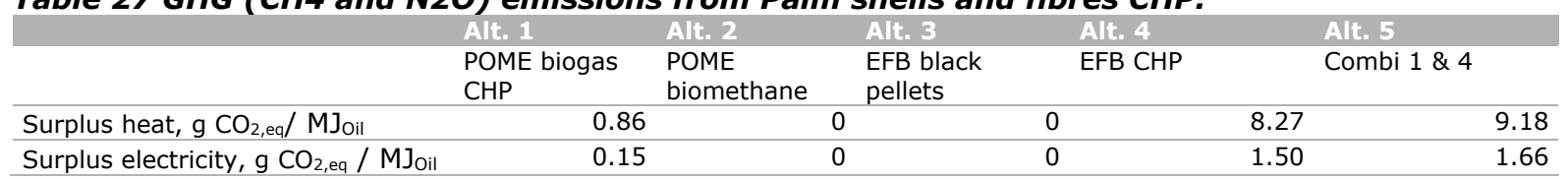

The credits from surplus heat and electricity are given in Table 28. The data in Table 28 are calculated from Tables 25 and 26 using the Biograce model (not visible in this report).

Table 28 Credits from surplus heat and electricity.

\begin{tabular}{lrrrrrr} 
& Alt. 1 Alt. 2 & Alt. 3 & Alt. 4 & Alt. 5 \\
Surplus heat, $\mathrm{g} \mathrm{CO}_{2, \text { eq }} / \mathrm{MJ}_{\text {oil }}$ & -1.07 & 0 & 0 & -10.25 & -11.38 \\
\hline Surplus electricity, $\mathrm{g} \mathrm{CO}_{2, \mathrm{eq}} / \mathrm{MJ}$ oil & -0.17 & 0 & 0 & -0.62 & -1.79 \\
\hline
\end{tabular}

Overall added credit from the consideration of the excess palm kernel shells and mesocarp fibres on the nonallocated results for each alternative is seen in the below table:

Table 29 Overall credits without allocation.

\begin{tabular}{|c|c|c|c|c|c|c|}
\hline & Alt. 1 & Alt. 2 & Alt. 3 & Alt. 4 & & Alt. 5 \\
\hline & $\begin{array}{l}\text { POME biogas } \\
\text { CHP }\end{array}$ & $\begin{array}{l}\text { POME } \\
\text { biomethane }\end{array}$ & $\begin{array}{l}\text { EFB black } \\
\text { pellets }\end{array}$ & EFB CHP & & Combi $1 \& 4$ \\
\hline Surplus heat, $\mathrm{g} \mathrm{CO}_{2, \mathrm{eq}} / \mathrm{MJ}_{\text {oil }}$ & -0.21 & & & 0 & -1.98 & -2.20 \\
\hline Surplus electricity, $\mathrm{g} \mathrm{CO}_{2, \mathrm{eq}} / \mathrm{MJ}_{\text {Oil }}$ & -0.02 & & & 0 & -0.12 & -0.13 \\
\hline Total, $\mathrm{g} \mathrm{CO}_{2, \mathrm{eq}} / \mathrm{MJ}_{\text {oil }}$ & -0.23 & & & 0 & -2.10 & -2.33 \\
\hline
\end{tabular}


The sum of the values from Table 27 and 28 are given in Table 29. Table 30 was calculated using the data from Table 29 and the allocation factors from Table 24.

Overall added credit from the consideration of the excess palm kernel shells and mesocarp fibres on the allocated results for each alternative is seen in the below table:

Table 30 Overall credits with allocation.

\begin{tabular}{|c|c|c|c|c|c|c|}
\hline & Alt. 1 & Alt. 2 & Alt. 3 & Alt. 4 & & Alt. 5 \\
\hline & $\begin{array}{l}\text { POME biogas } \\
\text { CHP }\end{array}$ & $\begin{array}{l}\text { POME } \\
\text { biomethane }\end{array}$ & $\begin{array}{l}\text { EFB black } \\
\text { pellets }\end{array}$ & EFB CHP & & Combi $1 \& 4$ \\
\hline Surplus heat, $\mathrm{g} \mathrm{CO}_{2, \mathrm{eq}} / \mathrm{MJ}_{\text {oil }}$ & -0.18 & & & 0 & -1.67 & -1.85 \\
\hline Surplus electricity, $\mathrm{g} \mathrm{CO}_{2 \text {,eq }} / \mathrm{MJ}_{\text {oil }}$ & -0.02 & & & 0 & -0.10 & -0.11 \\
\hline Total, g CO 2 eq / MJoil & -0.19 & & & 0 & -1.77 & -1.97 \\
\hline
\end{tabular}

Total non-allocated and allocated results with the added credit from the consideration of the excess palm kernel shells and mesocarp fibres can be found in Table 31.

Table 31 Total non-allocated and allocated credits for the use of excess palm kernel shells and mesocarp fibres.

\begin{tabular}{|c|c|c|c|c|c|c|}
\hline & Base Case & $\begin{array}{l}\text { Alt. 1: } \\
\text { POME } \\
\text { biogas CHP }\end{array}$ & $\begin{array}{l}\text { Alt. 2: POME } \\
\text { biomethane }\end{array}$ & $\begin{array}{l}\text { Alt. 3: EFB } \\
\text { black pellet }\end{array}$ & $\begin{array}{l}\text { Alt. 4: EFB } \\
\text { CHP }\end{array}$ & $\begin{array}{l}\text { Alt 5: } \\
\text { POME } \\
\text { biogas + } \\
\text { EFB CHP }\end{array}$ \\
\hline \multirow{3}{*}{$\begin{array}{r}\text { Non allocated } G H G \text { results, } \\
\text { gCO2,eq/MJPO } \\
\text { Allocated } G H G \text { results, } \\
\text { gCO2,eq/MJPO }\end{array}$} & 57.15 & 36.60 & 37.55 & 56.86 & 49.12 & 28.52 \\
\hline & 48.27 & 30.91 & 31.13 & 37.78 & 41.49 & 24.09 \\
\hline & Base Case & $\begin{array}{l}\text { Alt. 1: } \\
\text { POME } \\
\text { biogas CHP }\end{array}$ & $\begin{array}{l}\text { Alt. 2: POME } \\
\text { biomethane }\end{array}$ & $\begin{array}{l}\text { Alt. 3: EFB } \\
\text { black pellet }\end{array}$ & $\begin{array}{l}\text { Alt. 4: EFB } \\
\text { CHP }\end{array}$ & $\begin{array}{l}\text { Alt 5: } \\
\text { POME } \\
\text { biogas + } \\
\text { EFB CHP }\end{array}$ \\
\hline $\begin{array}{r}\text { Non allocated GHG results, } \\
g \mathrm{CO} 2, e q / \mathrm{kg} F F B\end{array}$ & 718.9 & 460.4 & 472.4 & 715.3 & 617.9 & 358.7 \\
\hline $\begin{array}{r}\text { Allocated } G H G \text { results, } \\
g \mathrm{CO} 2, e q / \mathrm{kg} F F B\end{array}$ & 607.3 & 388.9 & 391.6 & 475.3 & 521.9 & 303.0 \\
\hline
\end{tabular}

\subsection{Alternative accounting for the additional co-products through system expansion}

According to RED the "greenhouse gas emissions shall be divided between the fuel or its intermediate product and the co-products in proportion to their energy content (determined by lower heating value)". Therefore, energy allocation is applied to allocate the overall GHG impacts among the products. Alternatively, system expansion can be applied. In this method all emissions are assigned to the main product and credits are given for the co-products according to what they can replace on the market. The production of this product on the market than would be avoided. The avoided emissions from this is given as credit to the main product.

In this study, in case 2 methane is produced for transportation fuel and case 3 black pellets are produced. It can be considered that for case 2 the methane co-product produced will displace natural gas and we can give credit from the avoided production of natural gas. Similarly in case 3 , black pellets can replace coal and we can give credit from the avoided production of coal.

Case 2 Methane for transportation fuel

To avoid double counting the base-line, the allocated GHG emission, which was $31.13 \mathrm{~g} \mathrm{CO2,eq/MJPO}$ (Table 31), has to be changed in order to avoid double counting of the benefits of methane. For that, first the non-allocated emission has to be taken, which is $37.55 \mathrm{~g} \mathrm{CO2,eq/MJPO} \mathrm{(Table} \mathrm{31).} \mathrm{This} \mathrm{time} \mathrm{the}$ allocation presented in Table 17 is not applicable. Methane has to be removed from the allocations. This 
means that palm oil does not take $82.9 \%$ of the emissions anymore, but $84.5 \%$ (the same as in Table 15 ). The result is: $37.55 \times 0.845=31.7 \mathrm{~g} \mathrm{CO} 2$,eq/MJPO.

A credit from avoided natural gas will be added to this to calculate overall impact.

The impact of avoided production of natural gas can be calculated as:

Methane produced(= Natural gas avoided): 0.02 MJNG/MJPO. See table $39(0.34 / 13.73)$.

Natural gas emission factor: $66 \mathrm{~g} \mathrm{CO2,eq/MJNG}$

Avoided emission (credit): $1.5 \mathrm{~g} \mathrm{CO} 2, \mathrm{eq} / \mathrm{MJPO}$

Overall impact: $30.2 \mathrm{gCO}$,eq/MJPO

Interpretation: With system expansion a lower overall impact is calculated than by energy allocation (which was $31.1 \mathrm{gCO}$,eq/MJPO).

Case 3 Black pellets for energy

If energy allocation to black pellets was not done, the overall result would have been $48 \mathrm{~g} \mathrm{CO2,eq/MJPO}$.

The same type of correction as explained for case 2 was used. A credit from avoided coal will be added to

this to calculate overall impact.

The impact of avoided production of coal can be calculated as:

Black pellet produced: $0.32 \mathrm{MJBP} / \mathrm{MJPO}$ (see table $42: 4.57 / 13.73$ )

Black pellet LHV: $20.4 \mathrm{MJ} / \mathrm{kg}$

Coal LHV: $26.5 \mathrm{MJ} / \mathrm{kg}$, Coal emission factor: $112.3 \mathrm{~g} \mathrm{CO2,eq/MJ} \mathrm{(Guintoli} \mathrm{2017)}$

Avoided emission (credit): $0.32 \times 112.3 \times 20.4 / 26.5=27.7 \mathrm{~g} \mathrm{CO}$,eq/MJPO

Overall impact: $20.3 \mathrm{~g} \mathrm{CO}$,eq/MJPO

Interpretation: With system expansion a lower overall impact is calculated than by energy allocation (which was $37.8 \mathrm{~g} \mathrm{CO} 2$,eq/MJPO).

\subsection{Methane emission from EFB heaps in the field}

In our study the fate of EFB in the base case is composting and sales as compost. This is in agreement with the data in the BIOGRACE tool in which EFB is totally neutral with respect to greenhouse gas emissions. However, members of the Palmares team have observed that a spontaneous anaerobic digestion of EFB took place at some of the palm oil mills in Malaysia. In case methane is produced and emitted into the atmosphere by such process, a large contribution is delivered to the global warming potential. A worst (but realistic) methane production can be estimated. One ton of FFB dry matter produces 0.24 ton EFB dry matter. Only a part of the organic matter can be converted into biogas, not the inorganic part and recalcitrant organic matter. No exact data are available, but an educated guess for a worst case is that half of the dry matter of EFB is converted into biogas. That would be 0.12 ton organic matter and that would produce 0.12 ton biogas, of which $60 \% \mathrm{v} / \mathrm{v}$ is methane. This represents $42 \mathrm{~kg}$ methane. The global warming potential of $1 \mathrm{~kg}$ methane is $25 \mathrm{~kg} \mathrm{CO}_{2}$,eq, therefore the emission of methane by spontaneously digesting EFB heaps may be:

$1050 \mathrm{~kg} \mathrm{CO}$, eq per ton FFB dry matter, which is $83 \mathrm{~g} \mathrm{CO}_{2}$,eq per $\mathrm{MJ} \mathrm{PO}$.

This is even more than the greenhouse gas emission of the all other parts of the oil mill in the base case ( $57.15 \mathrm{~g} \mathrm{CO}_{2}$,eq per $\mathrm{MJ} \mathrm{PO}$ ). This means that proper storage of EFB needs attention and that immediate processing of EFB into black pellets or fuel for the CHP can help to prevent methane emission. 


\section{Conclusions}

All alternatives seem economically feasible. Alternatives 3,4 and 5 are economically favourable. The benefits from sales of EFB black pellets, mesocarp fibre and palm kernel shells are much greater that the costs involved to realize the new operation. The savings can be more than $10 \%$ of the palm oil value.

Substantial reduction of greenhouse gas emissions of the palm oil mill are possible in all five alternatives, due to the use of methane as a fuel, to the sales of residues as fuel and to recycling of nutrients. $50 \%$ reduction is possible using Dutch technologies. The largest effect is prevention of emission of greenhouse gases from lagoons. MF and PKS can be used and sold as fuel to replace methane in a CHP, which yields carbon credits but also additional emissions such as $\mathrm{N}_{2} \mathrm{O}$. The use of methane as bio-CNG in transportation and the use of black pellets as a fuel for export yield carbon credits as well. Storage of EFB deserves attention: methane emission by methanogenic putrefaction should be avoided. It can have a large effect on GHG emissions.

In a sensitivity analysis it appeared that a substantial effect is caused by emission by the CHP. Since EFB use in CHP is not described in Biograce it was assumed that emissions are comparable as $\mathrm{CH}_{4}$ in $\mathrm{CHP}$. When it is comparable to mesocarp in CHP: GHG emissions of alternatives 4 and 5 increases with $8.3 \mathrm{~g}$ $\mathrm{CO}_{2} \mathrm{eq} / \mathrm{MJ} \mathrm{PO}$ (about $20 \%$ increase). 
Edwards R., M. Padella, J. Giuntoli, R. Koeble, A.P. O'Connel, C. Bulgheroni \& L. Marelli (2019) Definition of input data to assess GHG default emissions from biofuels in EU legislation, v1d.

EU Renewable Energy Directive (RED) (Directive 2018/2001).

IFC Converting Biomass to Energy, 2017.

Garcia-Nunez, J.A., Ramirez-Contreras, N.E., Silva-Lora, E., Frear, C.S., Stockle, F. \& M. Garcia-Perez (2016a) Evolution of palm oil mills into bio-refineries: Literature review on current and potential uses of residual biomass and effluents; Resources, Conservation and Recycling 110:99-114.

Garcia-Nunez, J. A., Rodriguez, D.T, Fontanilla, C.C., Ramirez, N.E., Silva Lora, E.E., Frear, C.S., Stockle, C., Amonette, J. \& M. Garcia-Perez (2016b) Evaluation of alternatives for the evolution of palm oil mills into biorefineries; Biomass and Bioenergy 95:310-329.

Giuntoli, J. J. Giuntoli, A. Agostini, R. Edwards \& L. Marelli (2017) Solid and gaseous bioenergy pathways: input values and GHG emissions, v2.

Meesters, K. P. H. \& W. Elbersen (2018) Case study 5: Leaching as a biomass pre-treatment method for herbaceous biomass. Sugar cane trash and palm oil mill residues. Biomass pre-treatment for bioenergy. J. Koppejan, IEA Bioenergy.

Poh, P.E., Yong, W.E. \& M.F. Chong (2010) Palm Oil Mill Effluent (POME) Characteristic in High Crop Season and the Applicability of High-Rate Anaerobic Bioreactors for the Treatment of POME; Ind. Eng. Chem. Res.49(22):11732-11740.

Report on sustainability requirements for the use of solid and gaseous biomass sources in electricity, heating and cooling [COM/2010/11].

State of play on the sustainability of solid and gaseous biomass used for electricity, heating and cooling in the $\operatorname{EU}[\operatorname{SWD}(2014) 259]$.

Uslu, A., J. Daey Ouwens \& M. Boots (2018) CONCEPTADVIES SDE+ 2019: Vergisting. Planbureau voor de Leefomgeving; PBL publication nr. 3275.

Visser, H.J.M., F. Sebastiana, K. Meesters 7 W. Elbersen (2018) Creating green value from palm residues in Malaysia, a Palmares project. RVO Project K2K-16C1301.

Voogt, J., W. Elbersen, K. Meesters, S. Blankenborg, H. Langeveld \% F. Quist-Wessel (2018) Valorizing nutrients from palm oil mill effluent (POME) digestate. 26th European Biomass Conference and Exhibition, 14-17 May 2018, Copenhagen.

www.gasmalaysia.com/index.php/our-services/at-your-service/bills-payments/tariff-rates.

www.palmkernelshell.id/palm-kernel-shell-price/. 


\section{Annex 1 Mass and energy flow of base case and five alternatives}

1.1 The base case: business as usual

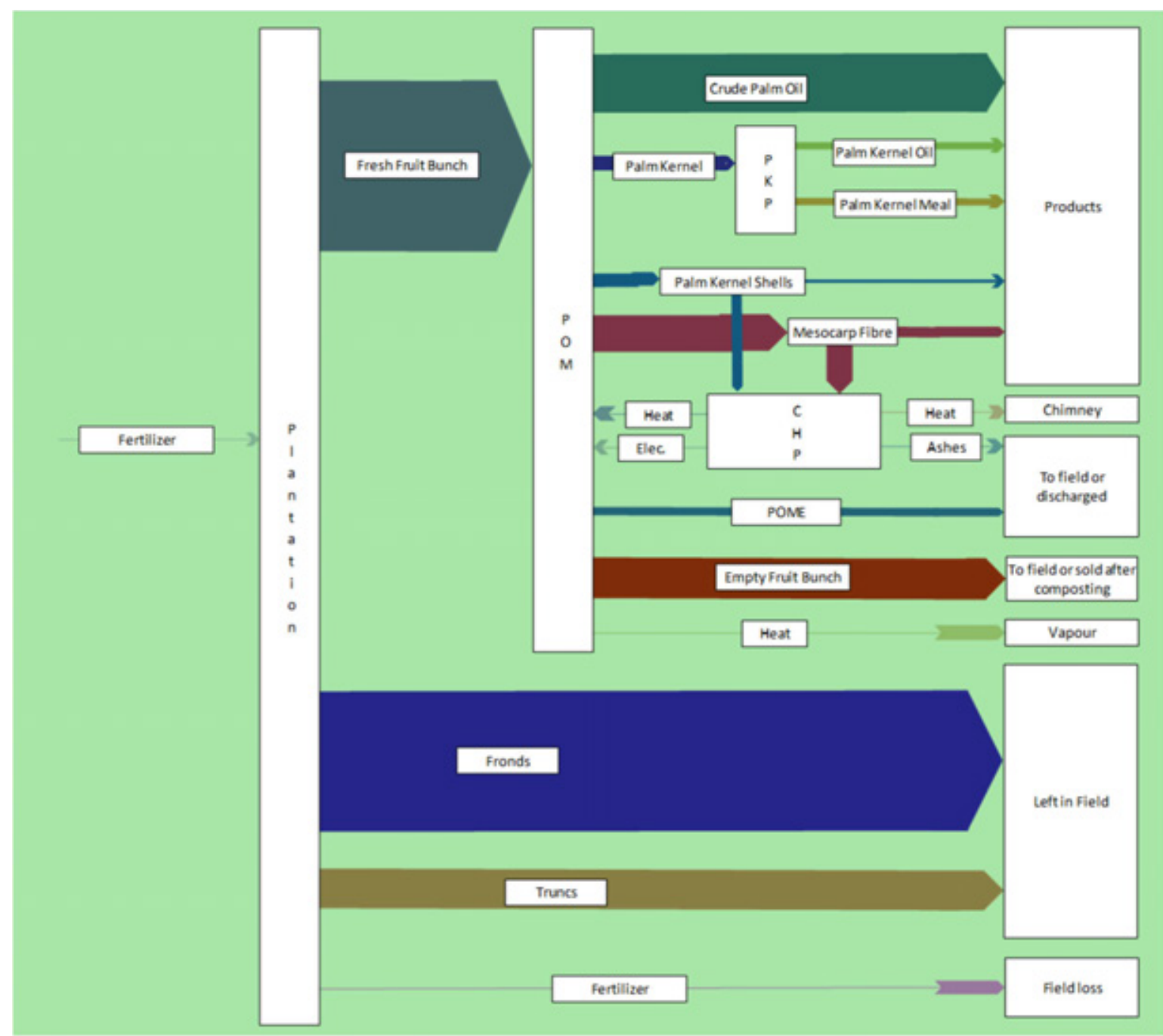

Figure 15 Dry matter balance (across the palm oil supply chain in Malaysia). Flow size is proportional to ton/h. 


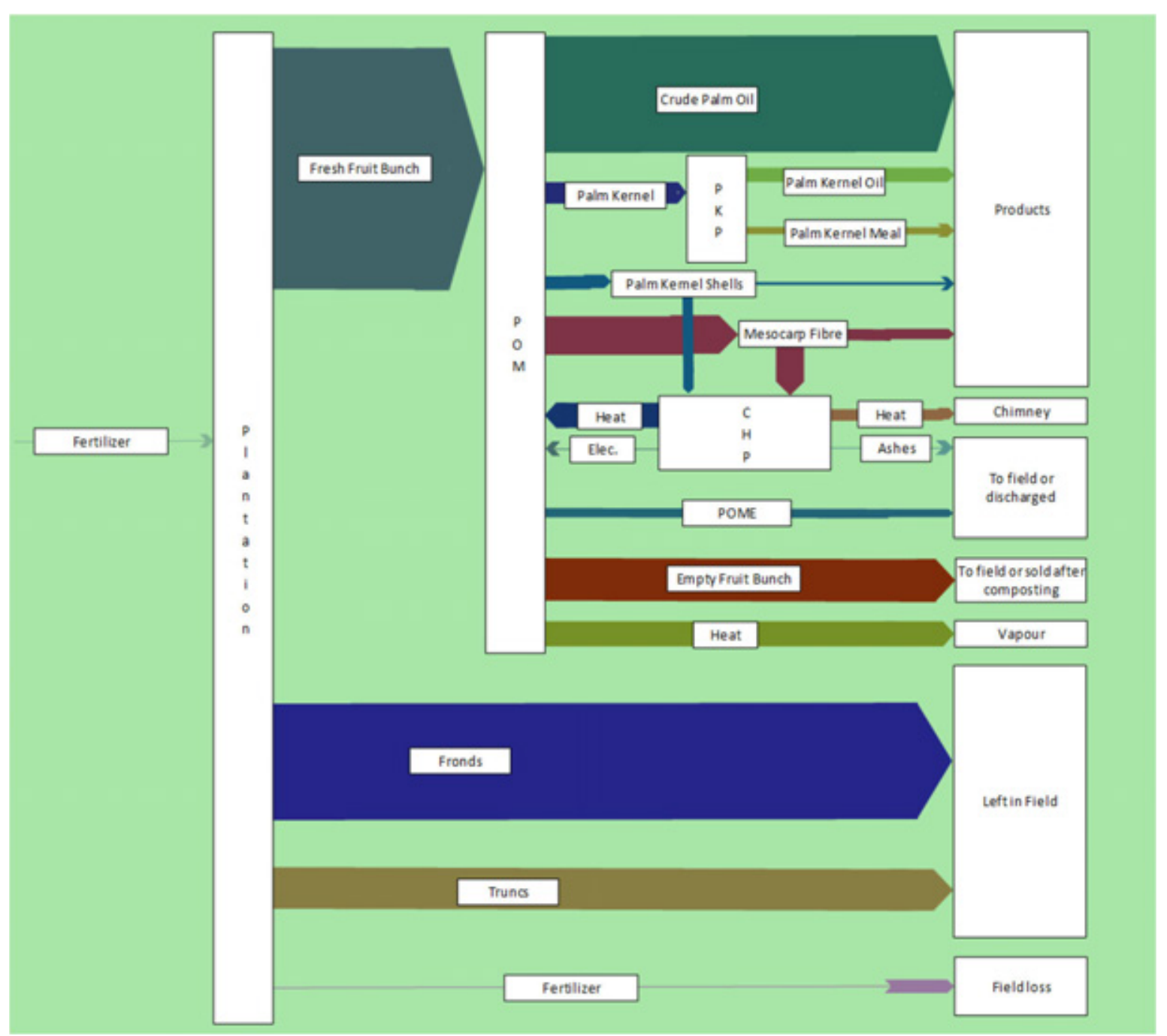

Figure 16 Energy balance (as higher heating value) across the palm oil supply chain in Malaysia. Flow size is proportional to $\mathrm{GJ} / \mathrm{h}$. 


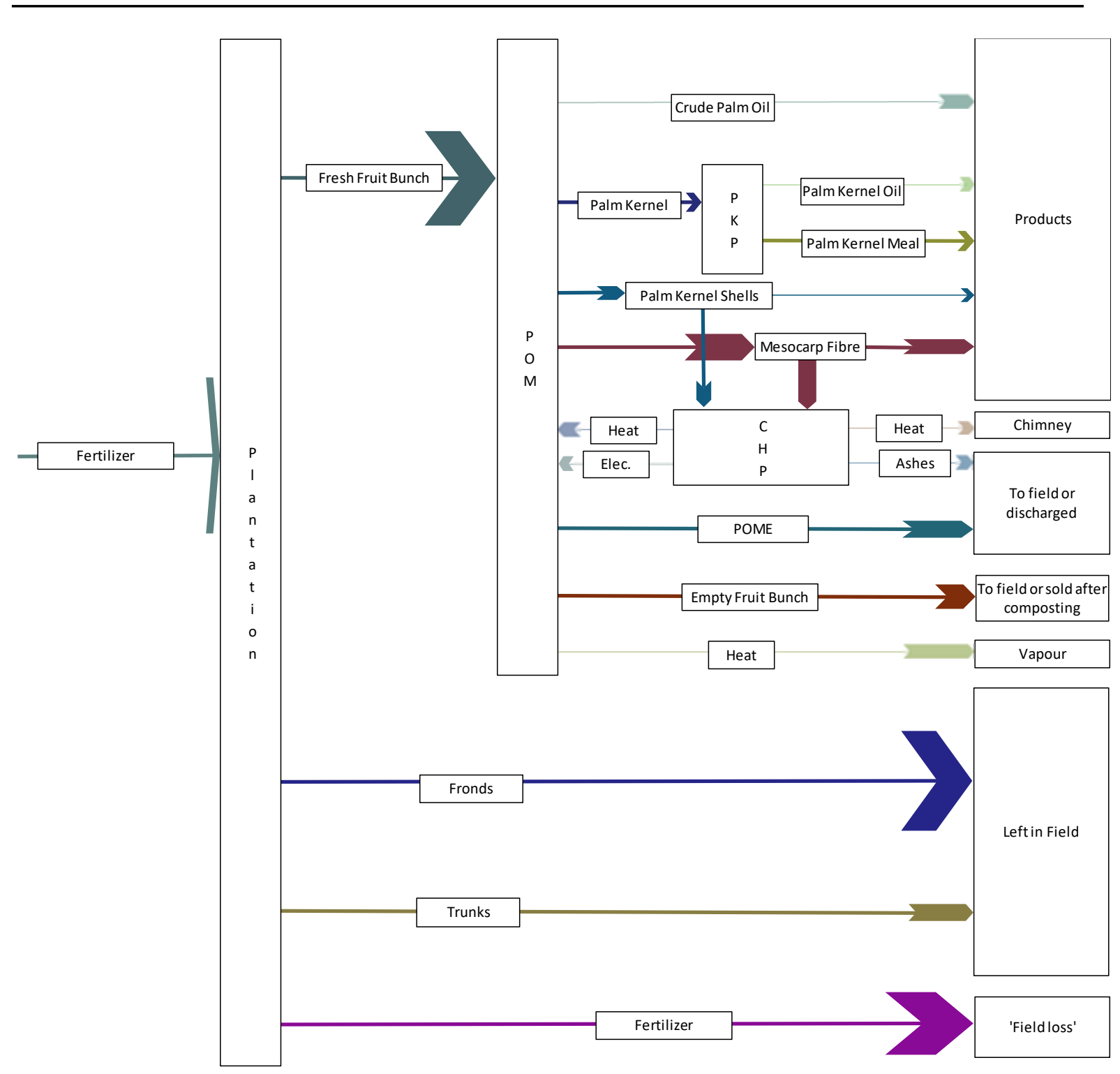

Figure 17 Nitrogen balance across the palm oil supply chain in Malaysia. Flow size is proportional to $\mathrm{kg}$ nitrogen/h. 


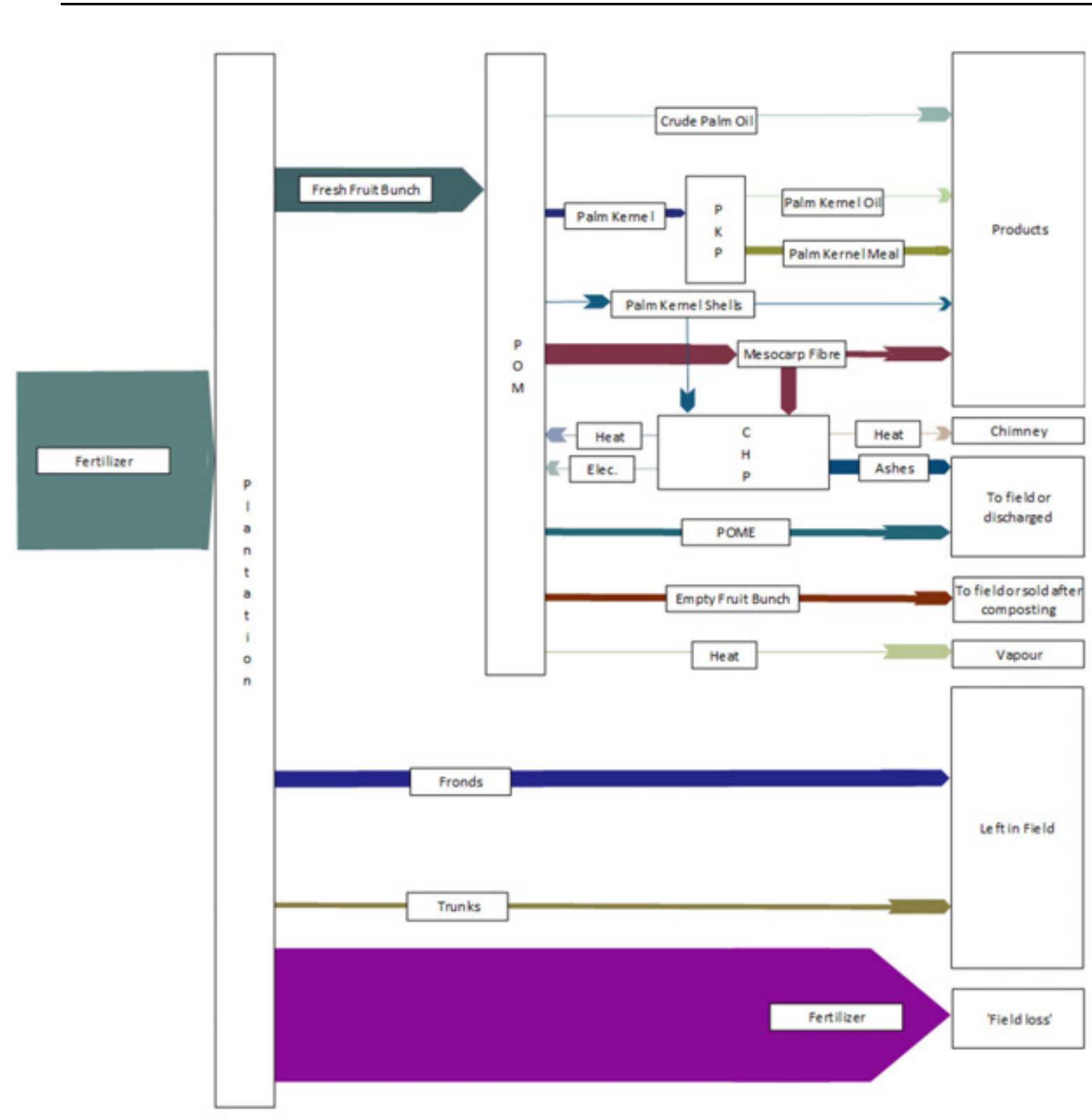

Figure 18 Phosphorus balance across the palm oil supply chain in Malaysia. Flow size is proportional to kg phosphorus/h. 


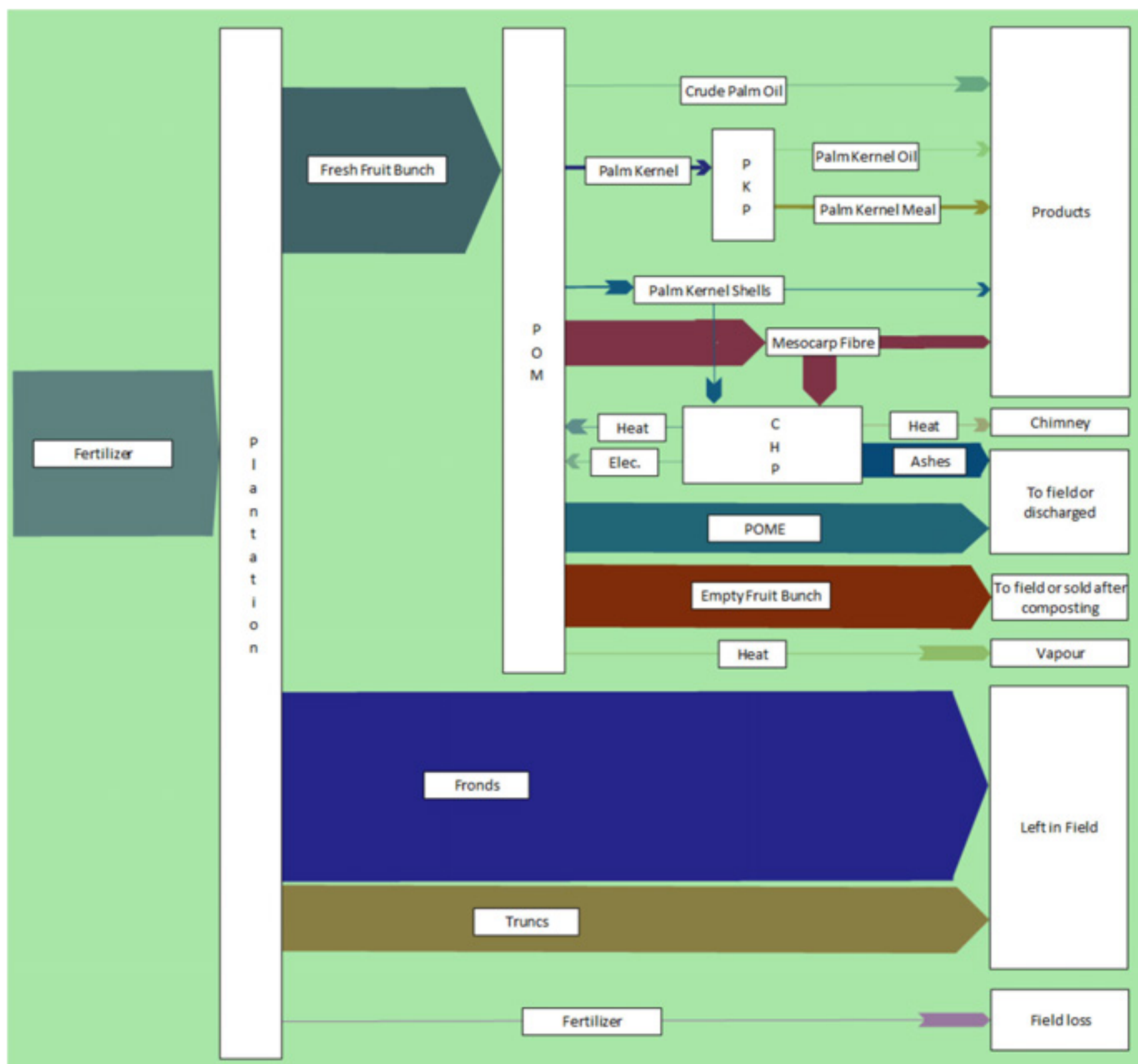

Figure 19 Potassium balance across the palm oil supply chain in Malaysia. Flow size is proportional to kg-potassium/h.

Table 32 Mass flows.

\begin{tabular}{|c|c|c|}
\hline \multicolumn{3}{|l|}{ Primary products } \\
\hline Material type & Mass flow (ton DM/h) & Destination \\
\hline Fresh Fruit Bunch & 1.0 & Palm oil mill \\
\hline Fronds & 0.83 & Left in the field \\
\hline Trunks & 0.24 & Left in the field \\
\hline
\end{tabular}




\begin{tabular}{|l|l|l|l|l|}
\hline \multicolumn{2}{|l|}{ Products from FFB from the palm oil mill } \\
\hline Material type & $\begin{array}{l}\text { Mass flow (ton } \\
\text { DM/h) }\end{array}$ & $\begin{array}{l}\text { Split up (material } \\
\text { type) }\end{array}$ & $\begin{array}{l}\text { Split up mass flow } \\
\text { (ton DM/h) }\end{array}$ & Destination \\
\hline Crude palm oil & 0.34 & & & Sales \\
\hline Palm kernel & 0.083 & Palm kernel oil & 0.042 & Sales \\
\hline & & Palm kernel meal & 0.041 & Sales \\
\hline Palm kernel shells & 0.077 & & 0.017 & Sales \\
\hline & & & 0.060 & CHP \\
\hline Mesocarp fibre & 0.22 & POME & 0.060 & Sales \\
\hline & & & 0.16 & CHP \\
\hline POME & 0.050 & 0.24 & 0.043 & Discharged \\
\hline
\end{tabular}

Table 33 Energy flows.

Primary products

\begin{tabular}{|l|l|l|}
\hline Material type & Energy flow $(\mathrm{GJ} / \mathrm{h})$ & Destination \\
\hline Fresh Fruit Bunch & 28.54 & Palm oil mill \\
\hline Fronds & 13.8 & Left in the field \\
\hline Trunks & 4.97 & Left in the field \\
\hline
\end{tabular}




\begin{tabular}{|c|c|c|c|c|c|c|}
\hline \multicolumn{7}{|c|}{ Products from FFB from the palm oil mill } \\
\hline Material type & $\begin{array}{l}\text { Higher } \\
\text { heating } \\
\text { value } \\
\text { (GJ/ton } \\
\text { DM) }\end{array}$ & $\begin{array}{l}\text { Energy flow } \\
(\mathrm{GJ} / \mathrm{h})\end{array}$ & $\begin{array}{l}\text { Split up } \\
\text { (material } \\
\text { type) }\end{array}$ & $\begin{array}{l}\text { Higher } \\
\text { heating } \\
\text { value } \\
\text { (GJ/ton } \\
\text { DM) }\end{array}$ & $\begin{array}{l}\text { Split up } \\
\text { energy flow } \\
(\mathrm{GJ} / \mathrm{h})\end{array}$ & Destination \\
\hline Crude palm oil & 40 & 13.73 & & & & Sales \\
\hline \multirow[t]{2}{*}{ Palm kernel } & 29.8 & 2.48 & $\begin{array}{l}\text { Palm kernel } \\
\text { oil }\end{array}$ & 40 & 1.67 & Sales \\
\hline & & & $\begin{array}{l}\text { Palm kernel } \\
\text { meal }\end{array}$ & 21 & 0.86 & Sales \\
\hline \multirow[t]{2}{*}{$\begin{array}{l}\text { Palm kernel } \\
\text { shells }\end{array}$} & 21 & 1.63 & & & 0.37 & Sales \\
\hline & & & & & 1.26 & $\mathrm{CHP}$ \\
\hline \multirow[t]{2}{*}{$\begin{array}{l}\text { Mesocarp } \\
\text { fibre }\end{array}$} & 21 & 4.54 & & & 1.27 & Sales \\
\hline & & & & & 3.27 & $\mathrm{CHP}$ \\
\hline \multirow[t]{2}{*}{ POME } & 21 & 1.05 & POME & 15.6 & 0.67 & Discharged \\
\hline & & & methane & 55.4 & 0.38 & Emission \\
\hline $\begin{array}{l}\text { Empty fruit } \\
\text { bunch }\end{array}$ & 21 & 5.01 & & & & $\begin{array}{l}\text { Composted } \\
\text { and sold }\end{array}$ \\
\hline
\end{tabular}

\begin{tabular}{|l|l|}
\hline \multicolumn{2}{|l|}{ Products from the CHP } \\
\hline Product type & Energy flow (GJ/h) \\
\hline Electricity & 0.20 \\
\hline Heat that can be used by the mill & 3.12 \\
\hline Heat loss (chimney) & 1.20 \\
\hline
\end{tabular}


Table 34 Nutrient flows.

\begin{tabular}{|c|c|c|c|c|}
\hline \multicolumn{5}{|l|}{ Fertilizer input } \\
\hline & $\mathrm{kg} \mathrm{N} / \mathrm{h}$ & $\mathrm{kg} \mathrm{P} / \mathrm{h}$ & $\mathrm{kg} \mathrm{K} / \mathrm{h}$ & \\
\hline Fertilizer & 9.17 & 5.60 & 9.50 & \\
\hline \multicolumn{5}{|c|}{ Primary products and fertilizer loss } \\
\hline & $\mathrm{kg} \mathrm{N} / \mathrm{h}$ & $\mathrm{kg} \mathrm{P} / \mathrm{h}$ & $\mathrm{kg} \mathrm{K} / \mathrm{h}$ & destination \\
\hline Fresh Fruit Bunch & 5.50 & 1.40 & 9.50 & Palm oil mill \\
\hline Fronds & 5.79 & 0.50 & 10.74 & $\begin{array}{l}\text { Left in the field, } \\
\text { nutrients recycled }\end{array}$ \\
\hline Trunks & 0.95 & 0.17 & 3.78 & $\begin{array}{l}\text { Left in the field, } \\
\text { nutrients recycled }\end{array}$ \\
\hline Fertilizer loss & 3.67 & 4.20 & 0 & Lost \\
\hline
\end{tabular}

\begin{tabular}{|c|c|c|c|c|c|c|c|c|}
\hline \multicolumn{9}{|c|}{ Products from FFB from the palm oil mill } \\
\hline $\begin{array}{l}\text { Material } \\
\text { type }\end{array}$ & $\begin{array}{l}\mathrm{kg} \\
\mathrm{N} / \mathrm{h}\end{array}$ & $\begin{array}{l}\mathrm{kg} \\
\mathrm{P} / \mathrm{h}\end{array}$ & $\mathrm{kg} \mathrm{K} / \mathrm{h}$ & $\begin{array}{l}\text { Split up } \\
\text { (material } \\
\text { type) }\end{array}$ & $\mathrm{kg} \mathrm{N} / \mathrm{h}$ & $\mathrm{kg} \mathrm{P} / \mathrm{h}$ & $\mathrm{kg} \mathrm{K} / \mathrm{h}$ & Destination \\
\hline $\begin{array}{l}\text { Crude palm } \\
\text { oil }\end{array}$ & 0 & 0 & 0 & & & & & Sales \\
\hline \multirow[t]{2}{*}{ Palm kernel } & 1.12 & 0.25 & 0.29 & $\begin{array}{l}\text { Palm kernel } \\
\text { oil }\end{array}$ & 0.01 & 0 & 0 & Sales \\
\hline & & & & $\begin{array}{l}\text { Palm kernel } \\
\text { meal }\end{array}$ & 1.11 & 0.25 & 0.29 & Sales \\
\hline \multirow{2}{*}{$\begin{array}{l}\text { Palm kernel } \\
\text { shells }\end{array}$} & 0.39 & 0 & 0.16 & & 0.09 & 0 & 0.04 & Sales \\
\hline & & & & & 0.30 & 0 & 0.12 & $\begin{array}{l}\text { CHP ash, } \\
\text { dumped }\end{array}$ \\
\hline \multirow{2}{*}{$\begin{array}{l}\text { Mesocarp } \\
\text { fibre }\end{array}$} & 1.51 & 0.65 & 2.60 & & 0.42 & 0.18 & 0.73 & Sales \\
\hline & & & & & 1.09 & 0.47 & 1.87 & $\begin{array}{l}\text { CHP ash } \\
\text { dumped }\end{array}$ \\
\hline POME & 1.00 & 0.25 & 2.85 & & & & & Discharged \\
\hline $\begin{array}{l}\text { Empty fruit } \\
\text { bunch }\end{array}$ & 1.43 & 0.24 & 3.58 & & & & & $\begin{array}{l}\text { Composted } \\
\text { and sold }\end{array}$ \\
\hline
\end{tabular}




\subsection{Alternative 1: POME conversion into biogas and use of biogas in an existing $\mathrm{CHP}$}

Table 35 Mass flows; changes in bold/orange.

\begin{tabular}{|c|c|c|}
\hline \multicolumn{3}{|l|}{ Primary products } \\
\hline Material type & Mass flow (ton DM/h) & Destination \\
\hline Fresh Fruit Bunch & 1.0 & Palm oil mill \\
\hline Fronds & 0.83 & Left in the field \\
\hline Trunks & 0.24 & Left in the field \\
\hline
\end{tabular}

\begin{tabular}{|c|c|c|c|c|}
\hline Material type & $\begin{array}{l}\text { Mass flow } \\
\text { (ton } \mathrm{DM} / \mathrm{h} \text { ) }\end{array}$ & $\begin{array}{l}\text { Split up } \\
\text { (material } \\
\text { type) }\end{array}$ & $\begin{array}{l}\text { Split up mass } \\
\text { flow (ton } \\
\text { DM/h) }\end{array}$ & Destination \\
\hline Crude palm oil & 0.34 & & & Sales \\
\hline \multirow[t]{2}{*}{ Palm kernel } & 0.083 & $\begin{array}{l}\text { Palm kernel } \\
\text { oil }\end{array}$ & 0.042 & Sales \\
\hline & & $\begin{array}{l}\text { Palm kernel } \\
\text { meal }\end{array}$ & 0.041 & Sales \\
\hline \multirow[t]{2}{*}{$\begin{array}{l}\text { Palm kernel } \\
\text { shells }\end{array}$} & 0.077 & & 0.053 & Sales \\
\hline & & & 0.024 & $\mathrm{CHP}$ \\
\hline \multirow[t]{2}{*}{$\begin{array}{l}\text { Mesocarp } \\
\text { fibre }\end{array}$} & 0.22 & & 0.060 & Sales \\
\hline & & & 0.16 & $\mathrm{CHP}$ \\
\hline \multirow[t]{2}{*}{ POME } & 0.050 & POME & 0.043 & $\begin{array}{l}\text { Irrigation of } \\
\text { field }\end{array}$ \\
\hline & & methane & 0.00670 & CHP \\
\hline $\begin{array}{l}\text { Empty fruit } \\
\text { bunch }\end{array}$ & 0.24 & & & $\begin{array}{l}\text { Composted } \\
\text { and sold }\end{array}$ \\
\hline
\end{tabular}

The difference with the base case:

- $\quad 36 \mathrm{~kg}$ palm kernel shells DM (per hour) shift from CHP use to sales

- $\quad 6.7 \mathrm{~kg}$ methane per hour now recovered and not emitted 
Table 36 Energy flows.

\begin{tabular}{|c|c|c|}
\hline \multicolumn{3}{|l|}{ Primary products } \\
\hline Material type & Energy flow (GJ/h) & Destination \\
\hline Fresh Fruit Bunch & 28.54 & Palm oil mill \\
\hline Fronds & 13.8 & Left in the field \\
\hline Trunks & 4.97 & Left in the field \\
\hline
\end{tabular}

\begin{tabular}{|c|c|c|c|c|c|c|}
\hline \multicolumn{7}{|c|}{ Products from FFB from the palm oil mill } \\
\hline Material type & $\begin{array}{l}\text { Higher } \\
\text { heating } \\
\text { value } \\
\text { (GJ/ton) }\end{array}$ & $\begin{array}{l}\text { Energy flow } \\
(\mathrm{GJ} / \mathrm{h})\end{array}$ & $\begin{array}{l}\text { Split up } \\
\text { (material } \\
\text { type) }\end{array}$ & $\begin{array}{l}\text { Higher } \\
\text { heating } \\
\text { value } \\
\text { (GJ/ton) }\end{array}$ & $\begin{array}{l}\text { Split up } \\
\text { energy flow } \\
(\mathrm{GJ} / \mathrm{h})\end{array}$ & Destination \\
\hline Crude palm oil & 40 & 13.73 & & & & Sales \\
\hline \multirow[t]{2}{*}{ Palm kernel } & 29.8 & 2.48 & $\begin{array}{l}\text { Palm kernel } \\
\text { oil }\end{array}$ & 40 & 1.67 & Sales \\
\hline & & & $\begin{array}{l}\text { Palm kernel } \\
\text { meal }\end{array}$ & 21 & 0.86 & Sales \\
\hline \multirow[t]{2}{*}{$\begin{array}{l}\text { Palm kernel } \\
\text { shells }\end{array}$} & 21 & 1.63 & & & 0.74 & Sales \\
\hline & & & & & 0.89 & $\mathrm{CHP}$ \\
\hline \multirow[t]{2}{*}{$\begin{array}{l}\text { Mesocarp } \\
\text { fibre }\end{array}$} & 21 & 4.54 & & & 1.27 & Sales \\
\hline & & & & & 3.27 & $\mathrm{CHP}$ \\
\hline \multirow[t]{2}{*}{ POME } & 21 & 1.05 & POME & 15.6 & 0.68 & $\begin{array}{l}\text { Irrigation of } \\
\text { field }\end{array}$ \\
\hline & & & methane & 55.4 & 0.37 & CHP \\
\hline $\begin{array}{l}\text { Empty fruit } \\
\text { bunch }\end{array}$ & 21 & 5.01 & & & & $\begin{array}{l}\text { Composted } \\
\text { and sold }\end{array}$ \\
\hline
\end{tabular}

\begin{tabular}{|l|l|}
\hline \multicolumn{2}{|l|}{ Products from the CHP } \\
\hline Product type & Energy flow (GJ/h) \\
\hline Electricity & 0.20 \\
\hline Heat that can be used by the mill & 3.12 \\
\hline Heat loss (chimney) & 1.20 \\
\hline
\end{tabular}


The difference with the base case:

- $\quad 0.37 \mathrm{GJ} / \mathrm{h}$ from palm kernel shells shift from CHP use to sales

- $\quad 0.37 \mathrm{GJ} / \mathrm{h}$ now recovered as methane from POME and used in the CHP

Table 37 Nutrient flows.

\begin{tabular}{|c|c|c|c|c|}
\hline \multicolumn{5}{|l|}{ Fertilizer input } \\
\hline & $\mathrm{kg} \mathrm{N} / \mathrm{h}$ & $\mathrm{kg} \mathrm{P/h}$ & $\mathrm{kg} \mathrm{K} / \mathrm{h}$ & \\
\hline Fertilizer & 8.17 & 5.35 & 6.65 & \\
\hline \multicolumn{5}{|c|}{ Primary products and fertilizer loss } \\
\hline & $\mathrm{kg} \mathrm{N} / \mathrm{h}$ & $\mathrm{kg} \mathrm{P} / \mathrm{h}$ & $\mathrm{kg} \mathrm{K} / \mathrm{h}$ & destination \\
\hline Fresh Fruit Bunch & 5.50 & 1.40 & 9.50 & Palm oil mill \\
\hline Fronds & 5.79 & 0.50 & 10.74 & $\begin{array}{l}\text { Left in the field, } \\
\text { nutrients recycled }\end{array}$ \\
\hline Trunks & 0.95 & 0.17 & 3.78 & $\begin{array}{l}\text { Left in the field, } \\
\text { nutrients recycled }\end{array}$ \\
\hline Fertilizer loss & 3.67 & 4.20 & 0 & Lost \\
\hline
\end{tabular}




\begin{tabular}{|c|c|c|c|c|c|c|c|c|}
\hline \multicolumn{9}{|c|}{ Products from FFB from the palm oil mill } \\
\hline $\begin{array}{l}\text { Material } \\
\text { type }\end{array}$ & $\begin{array}{l}\mathrm{kg} \\
\mathrm{N} / \mathrm{h}\end{array}$ & $\begin{array}{l}\mathrm{kg} \\
\mathrm{P} / \mathrm{h}\end{array}$ & $\mathrm{kg} \mathrm{K} / \mathrm{h}$ & $\begin{array}{l}\text { Split up } \\
\text { (material } \\
\text { type) }\end{array}$ & $\mathrm{kg} \mathrm{N} / \mathrm{h}$ & $\mathrm{kg} \mathrm{P} / \mathrm{h}$ & $\mathrm{kg} \mathrm{K} / \mathrm{h}$ & Destination \\
\hline $\begin{array}{l}\text { Crude palm } \\
\text { oil }\end{array}$ & 0 & 0 & 0 & & & & & Sales \\
\hline \multirow[t]{2}{*}{ Palm kernel } & 1.12 & 0.25 & 0.29 & $\begin{array}{l}\text { Palm kernel } \\
\text { oil }\end{array}$ & 0.01 & 0 & 0 & Sales \\
\hline & & & & $\begin{array}{l}\text { Palm kernel } \\
\text { meal }\end{array}$ & 1.11 & 0.25 & 0.29 & Sales \\
\hline \multirow{2}{*}{$\begin{array}{l}\text { Palm kernel } \\
\text { shells }\end{array}$} & 0.39 & 0 & 0.16 & & 0.18 & 0 & 0.07 & Sales \\
\hline & & & & & 0.21 & 0 & 0.09 & $\begin{array}{l}\text { CHP ash, } \\
\text { dumped }\end{array}$ \\
\hline \multirow{2}{*}{$\begin{array}{l}\text { Mesocarp } \\
\text { fibre }\end{array}$} & 1.51 & 0.65 & 2.60 & & 0.42 & 0.18 & 0.73 & Sales \\
\hline & & & & & 1.09 & 0.47 & 1.87 & $\begin{array}{l}\text { CHP ash } \\
\text { dumped }\end{array}$ \\
\hline POME & 1.00 & 0.25 & 2.85 & & & & & $\begin{array}{l}\text { Irrigation of } \\
\text { field }\end{array}$ \\
\hline $\begin{array}{l}\text { Empty fruit } \\
\text { bunch }\end{array}$ & 1.43 & 0.24 & 3.58 & & & & & $\begin{array}{l}\text { Composted } \\
\text { and sold }\end{array}$ \\
\hline
\end{tabular}

The difference with the base case:

- $\quad 1 \mathrm{~kg} \mathrm{~N}, 0.15 \mathrm{~kg} P$ and $2.85 \mathrm{~kg} \mathrm{~K}$ per hour recycled via POME to the plantation.

- Same amount lower input of (synthetic) nutrients 


\subsection{Alternative 2: POME conversion into biogas and use of biogas as transportation fuel}

Table 38 Mass flows.

\begin{tabular}{|c|c|c|}
\hline \multicolumn{3}{|l|}{ Primary products } \\
\hline Material type & Mass flow (ton DM/h) & Destination \\
\hline Fresh Fruit Bunch & 1.0 & Palm oil mill \\
\hline Fronds & 0.83 & Left in the field \\
\hline Trunks & 0.24 & Left in the field \\
\hline
\end{tabular}

\begin{tabular}{|c|c|c|c|c|}
\hline \multicolumn{5}{|c|}{ Products from FFB from the palm oil mill } \\
\hline Material type & $\begin{array}{l}\text { Mass flow (ton } \\
\mathrm{DM} / \mathrm{h} \text { ) }\end{array}$ & $\begin{array}{l}\text { Split up (material } \\
\text { type) }\end{array}$ & $\begin{array}{l}\text { Split up mass flow } \\
\text { (ton DM/h) }\end{array}$ & Destination \\
\hline Crude palm oil & 0.34 & & & Sales \\
\hline \multirow[t]{2}{*}{ Palm kernel } & 0.083 & Palm kernel oil & 0.042 & Sales \\
\hline & & Palm kernel meal & 0.041 & Sales \\
\hline \multirow[t]{2}{*}{ Palm kernel shells } & 0.077 & & 0.017 & Sales \\
\hline & & & 0.060 & $\mathrm{CHP}$ \\
\hline \multirow[t]{2}{*}{ Mesocarp fibre } & 0.22 & & 0.060 & Sales \\
\hline & & & 0.16 & $\mathrm{CHP}$ \\
\hline \multirow[t]{3}{*}{ POME } & 0.050 & POME & 0.043 & Irrigation of field \\
\hline & & methane & 0.0057 & $\begin{array}{l}\text { Sold as } \\
\text { transportation fuel }\end{array}$ \\
\hline & & methane & 0.001 & CHP \\
\hline Empty fruit bunch & 0.24 & & & $\begin{array}{l}\text { Composted and } \\
\text { sold }\end{array}$ \\
\hline
\end{tabular}

The difference with the base case:

- $\quad 6.1 \mathrm{~kg}$ methane per hour now recovered and sold as transportation fuel, and not emitted 
Table 39 Energy flows.

\begin{tabular}{|c|c|c|}
\hline \multicolumn{3}{|l|}{ Primary products } \\
\hline Material type & Energy flow $(\mathrm{GJ} / \mathrm{h})$ & Destination \\
\hline Fresh Fruit Bunch & 28.54 & Palm oil mill \\
\hline Fronds & 13.8 & Left in the field \\
\hline Trunks & 4.97 & Left in the field \\
\hline
\end{tabular}

\begin{tabular}{|c|c|c|c|c|c|c|}
\hline \multicolumn{7}{|c|}{ Products from FFB from the palm oil mill } \\
\hline Material type & $\begin{array}{l}\text { Higher } \\
\text { heating } \\
\text { value } \\
\text { (GJ/ton } \\
\text { DM) }\end{array}$ & $\begin{array}{l}\text { Energy flow } \\
(\mathrm{GJ} / \mathrm{h})\end{array}$ & $\begin{array}{l}\text { Split up } \\
\text { (material } \\
\text { type) }\end{array}$ & $\begin{array}{l}\text { Higher } \\
\text { heating } \\
\text { value } \\
\text { (GJ/ton } \\
\text { DM) }\end{array}$ & $\begin{array}{l}\text { Split up } \\
\text { energy flow } \\
(\mathrm{GJ} / \mathrm{h})\end{array}$ & Destination \\
\hline Crude palm oil & 40 & 13.73 & & & & Sales \\
\hline \multirow[t]{2}{*}{ Palm kernel } & 29.8 & 2.48 & $\begin{array}{l}\text { Palm kernel } \\
\text { oil }\end{array}$ & 40 & 1.67 & Sales \\
\hline & & & $\begin{array}{l}\text { Palm kernel } \\
\text { meal }\end{array}$ & 21 & 0.86 & Sales \\
\hline \multirow[t]{2}{*}{$\begin{array}{l}\text { Palm kernel } \\
\text { shells }\end{array}$} & 21 & 1.63 & & & 0.37 & Sales \\
\hline & & & & & 1.26 & $\mathrm{CHP}$ \\
\hline \multirow[t]{2}{*}{$\begin{array}{l}\text { Mesocarp } \\
\text { fibre }\end{array}$} & 21 & 4.54 & & & 1.27 & Sales \\
\hline & & & & & 3.27 & $\mathrm{CHP}$ \\
\hline \multirow[t]{3}{*}{ POME } & 21 & 1.05 & POME & 15.6 & 0.68 & Irrigation of field \\
\hline & & & methane & 55.4 & 0.34 & $\begin{array}{l}\text { Sold as } \\
\text { transportation } \\
\text { fuel }\end{array}$ \\
\hline & & & methane & 55.4 & 0.03 & CHP \\
\hline $\begin{array}{l}\text { Empty fruit } \\
\text { bunch }\end{array}$ & 21 & 5.01 & & & & $\begin{array}{l}\text { Composted and } \\
\text { sold }\end{array}$ \\
\hline
\end{tabular}




\begin{tabular}{|l|l|}
\hline \multicolumn{2}{|l|}{ Products from the CHP } \\
\hline Product type & Energy flow (GJ/h) \\
\hline Electricity & 0.21 \\
\hline Heat that can be used by the mill & 3.13 \\
\hline Heat loss (chimney) & 1.21 \\
\hline
\end{tabular}

The difference with the base case:

- $\quad 0.34 \mathrm{GJ} / \mathrm{h}$ now recovered as methane from POME and sold as transportation fuel.

- $\quad 0.01 \mathrm{GJ} / \mathrm{h}$ more electricity and $0.02 \mathrm{GJ} / \mathrm{h}$ more heat because of use of a small part of the biogas in CHP.

Table 40 Nutrient flows.

\begin{tabular}{|l|l|l|l|l|l|}
\hline \multicolumn{2}{|l|}{ Fertilizer input } & $\mathrm{kg} \mathrm{N} / \mathrm{h}$ & $\mathrm{kg} \mathrm{P} / \mathrm{h}$ & $\mathrm{kg} \mathrm{K} / \mathrm{h}$ & \\
\hline Fertilizer & 8.17 & 5.35 & 6.65 & \\
\hline Primary products and fertilizer loss & $\mathrm{kg} \mathrm{N} / \mathrm{h}$ & $\mathrm{kg} \mathrm{P} / \mathrm{h}$ & $\mathrm{kg} \mathrm{K} / \mathrm{h}$ & destination \\
\hline & 5.50 & 1.40 & 9.50 & Palm oil mill \\
\hline Fresh Fruit Bunch & 5.79 & 0.50 & 10.74 & $\begin{array}{l}\text { Left in } \\
\text { nutrients recycled }\end{array}$ \\
\hline Fronds & & & & the \\
\hline Trunks & 0.95 & 0.17 & 3.78 & nutrients recycled \\
\hline
\end{tabular}




\begin{tabular}{|c|c|c|c|c|c|c|c|c|}
\hline \multicolumn{9}{|c|}{ Products from FFB from the palm oil mill } \\
\hline $\begin{array}{l}\text { Material } \\
\text { type }\end{array}$ & $\begin{array}{l}\mathrm{kg} \\
\mathrm{N} / \mathrm{h}\end{array}$ & $\begin{array}{l}\mathrm{kg} \\
\mathrm{P} / \mathrm{h}\end{array}$ & $\mathrm{kg} \mathrm{K} / \mathrm{h}$ & $\begin{array}{l}\text { Split up } \\
\text { (material } \\
\text { type) }\end{array}$ & $\mathrm{kg} \mathrm{N} / \mathrm{h}$ & $\mathrm{kg} \mathrm{P} / \mathrm{h}$ & $\mathrm{kg} \mathrm{K} / \mathrm{h}$ & Destination \\
\hline $\begin{array}{l}\text { Crude palm } \\
\text { oil }\end{array}$ & 0 & 0 & 0 & & & & & Sales \\
\hline \multirow[t]{2}{*}{ Palm kernel } & 1.12 & 0.25 & 0.29 & $\begin{array}{l}\text { Palm kernel } \\
\text { oil }\end{array}$ & 0.01 & 0 & 0 & Sales \\
\hline & & & & $\begin{array}{l}\text { Palm kernel } \\
\text { meal }\end{array}$ & 1.11 & 0.25 & 0.29 & Sales \\
\hline \multirow{2}{*}{$\begin{array}{l}\text { Palm kernel } \\
\text { shells }\end{array}$} & 0.39 & 0 & 0.16 & & 0.09 & 0 & 0.04 & Sales \\
\hline & & & & & 0.30 & 0 & 0.12 & $\begin{array}{l}\text { CHP ash, } \\
\text { dumped }\end{array}$ \\
\hline \multirow{2}{*}{$\begin{array}{l}\text { Mesocarp } \\
\text { fibre }\end{array}$} & 1.51 & 0.65 & 2.60 & & 0.42 & 0.18 & 0.73 & Sales \\
\hline & & & & & 1.09 & 0.47 & 1.87 & $\begin{array}{l}\text { CHP ash } \\
\text { dumped }\end{array}$ \\
\hline POME & 1.00 & 0.25 & 2.85 & & & & & $\begin{array}{l}\text { Irrigation of } \\
\text { field }\end{array}$ \\
\hline $\begin{array}{l}\text { Empty fruit } \\
\text { bunch }\end{array}$ & 1.43 & 0.24 & 3.58 & & & & & $\begin{array}{l}\text { Composted } \\
\text { and sold }\end{array}$ \\
\hline
\end{tabular}

The difference with the base case:

- $\quad 1 \mathrm{~kg} \mathrm{~N}, 0.15 \mathrm{~kg} P$ and $2.85 \mathrm{~kg} \mathrm{~K}$ per hour recycled via POME to the plantation.

- Same amount lower input of (synthetic) nutrients 


\subsection{Alternative 3: EFB conversion into black pellets (by TORWASH $®$ )}

Table 41 Mass flows.

\begin{tabular}{|c|c|c|}
\hline \multicolumn{3}{|l|}{ Primary products } \\
\hline Material type & Mass flow (ton $\mathrm{DM} / \mathrm{h}$ ) & Destination \\
\hline Fresh Fruit Bunch & 1.0 & Palm oil mill \\
\hline Fronds & 0.83 & Left in the field \\
\hline Trunks & 0.24 & Left in the field \\
\hline
\end{tabular}

\begin{tabular}{|c|c|c|c|c|}
\hline \multicolumn{5}{|c|}{ Products from FFB from the palm oil mill } \\
\hline Material type & $\begin{array}{l}\text { Mass flow (ton } \\
\mathrm{DM} / \mathrm{h} \text { ) }\end{array}$ & $\begin{array}{l}\text { Split up (material } \\
\text { type) }\end{array}$ & $\begin{array}{l}\text { Split up mass flow } \\
\text { (ton DM/h) }\end{array}$ & Destination \\
\hline Crude palm oil & 0.34 & & & Sales \\
\hline \multirow[t]{2}{*}{ Palm kernel } & 0.083 & Palm kernel oil & 0.042 & Sales \\
\hline & & Palm kernel meal & 0.041 & Sales \\
\hline \multirow[t]{2}{*}{ Palm kernel shells } & 0.077 & & 0.017 & Sales \\
\hline & & & 0.060 & $\mathrm{CHP}$ \\
\hline \multirow[t]{2}{*}{ Mesocarp fibre } & 0.22 & & 0.060 & Sales \\
\hline & & & 0.16 & $\mathrm{CHP}$ \\
\hline \multirow[t]{2}{*}{ POME } & 0.050 & POME & 0.043 & Discharged \\
\hline & & methane & 0.00685 & Emission \\
\hline \multirow[t]{2}{*}{ Empty fruit bunch } & 0.24 & EFB black pellets & 0.198 & $\begin{array}{l}\text { Sold and exported } \\
\text { as fuel }\end{array}$ \\
\hline & & EFB effluent & 0.042 & $\begin{array}{ll}\text { For internal } & \text { use } \\
\text { (energy } & \text { for } \\
\text { TORWASH }^{\circledR} \text { ) } & \end{array}$ \\
\hline
\end{tabular}

The difference with the base case:

- Empty fruit bunch now used to produce black pellets for export (198 kg DM/h). 
Table 42 Energy flows.

\begin{tabular}{|c|c|c|}
\hline \multicolumn{3}{|l|}{ Primary products } \\
\hline Material type & Energy flow (GJ/h) & Destination \\
\hline Fresh Fruit Bunch & 28.54 & Palm oil mill \\
\hline Fronds & 13.8 & Left in the field \\
\hline Trunks & 4.97 & Left in the field \\
\hline
\end{tabular}

\begin{tabular}{|c|c|c|c|c|c|c|}
\hline \multicolumn{7}{|c|}{ Products from FFB from the palm oil mill } \\
\hline Material type & $\begin{array}{l}\text { Higher } \\
\text { heating } \\
\text { value } \\
\text { (GJ/ton } \\
\text { DM) }\end{array}$ & $\begin{array}{l}\text { Energy flow } \\
(\mathrm{GJ} / \mathrm{h})\end{array}$ & $\begin{array}{l}\text { Split up } \\
\text { (material } \\
\text { type) }\end{array}$ & $\begin{array}{l}\text { Higher } \\
\text { heating } \\
\text { value } \\
\text { (GJ/ton } \\
\text { DM) }\end{array}$ & $\begin{array}{l}\text { Split up } \\
\text { energy flow } \\
(G J / h)\end{array}$ & Destination \\
\hline Crude palm oil & 40 & 13.73 & & & & Sales \\
\hline \multirow[t]{2}{*}{ Palm kernel } & 29.8 & 2.48 & $\begin{array}{l}\text { Palm kernel } \\
\text { oil }\end{array}$ & 40 & 1.67 & Sales \\
\hline & & & $\begin{array}{l}\text { Palm kernel } \\
\text { meal }\end{array}$ & 21 & 0.86 & Sales \\
\hline \multirow[t]{2}{*}{$\begin{array}{l}\text { Palm kernel } \\
\text { shells }\end{array}$} & 21 & 1.63 & & & 0.37 & Sales \\
\hline & & & & & 1.26 & $\mathrm{CHP}$ \\
\hline \multirow[t]{2}{*}{$\begin{array}{l}\text { Mesocarp } \\
\text { fibre }\end{array}$} & 21 & 4.54 & & & 1.27 & Sales \\
\hline & & & & & 3.27 & $\mathrm{CHP}$ \\
\hline \multirow[t]{2}{*}{ POME } & 21 & 1.05 & POME & 15.6 & 0.67 & Discharged \\
\hline & & & methane & 55.4 & 0.38 & Emission \\
\hline \multirow[t]{2}{*}{$\begin{array}{l}\text { Empty fruit } \\
\text { bunch }\end{array}$} & 21 & 5.01 & $\begin{array}{l}\text { EFB black } \\
\text { pellets }\end{array}$ & 23.1 & 4.57 & $\begin{array}{l}\text { Sold and } \\
\text { exported as } \\
\text { fuel }\end{array}$ \\
\hline & & & EFB effluent & 10.5 & 0.44 & $\begin{array}{l}\text { For internal use } \\
\text { (energy for } \\
\text { TORWASH }^{\circledR} \text { ) }\end{array}$ \\
\hline
\end{tabular}

The difference with the base case:

- $4.57 \mathrm{GJ} / \mathrm{h}$ from EFB in form of black pellets for export 
Table 43 Nutrient flows.

\begin{tabular}{|l|l|l|l|l|l|}
\hline \multicolumn{2}{|l|}{ Fertilizer input } & kg N/h & $\mathrm{kg} \mathrm{P} / \mathrm{h}$ & $\mathrm{kg} \mathrm{K} / \mathrm{h}$ & \\
\hline Fertilizer & 7,98 & 5.39 & 6.06 & \\
\hline Primary products and fertilizer loss & $\mathrm{kg} \mathrm{N} / \mathrm{h}$ & $\mathrm{kg} \mathrm{P} / \mathrm{h}$ & $\mathrm{kg} \mathrm{K} / \mathrm{h}$ & destination \\
\hline & 5.50 & 1.40 & 9.50 & Palm oil mill \\
\hline Fresh Fruit Bunch & 5.79 & 0.50 & 10.74 & $\begin{array}{l}\text { Left in the field, } \\
\text { nutrients recycled }\end{array}$ \\
\hline Fronds & & & & $\begin{array}{l}\text { Left in the field, } \\
\text { nutrients recycled }\end{array}$ \\
\hline Trunks & 0.95 & 0.17 & 3.78 & Lost \\
\hline
\end{tabular}




\begin{tabular}{|c|c|c|c|c|c|c|c|c|}
\hline \multicolumn{9}{|c|}{ Products from FFB from the palm oil mill } \\
\hline $\begin{array}{l}\text { Material } \\
\text { type }\end{array}$ & $\begin{array}{l}\mathrm{kg} \\
\mathrm{N} / \mathrm{h}\end{array}$ & $\begin{array}{l}\mathrm{kg} \\
\mathrm{P} / \mathrm{h}\end{array}$ & $\mathrm{kg} \mathrm{K} / \mathrm{h}$ & $\begin{array}{l}\text { Split up } \\
\text { (material } \\
\text { type) }\end{array}$ & $\mathrm{kg} \mathrm{N} / \mathrm{h}$ & $\mathrm{kg} \mathrm{P} / \mathrm{h}$ & $\mathrm{kg} \mathrm{K} / \mathrm{h}$ & Destination \\
\hline $\begin{array}{l}\text { Crude palm } \\
\text { oil }\end{array}$ & 0 & 0 & 0 & & & & & Sales \\
\hline \multirow[t]{2}{*}{ Palm kernel } & 1.12 & 0.25 & 0.29 & $\begin{array}{l}\text { Palm kernel } \\
\text { oil }\end{array}$ & 0.01 & 0 & 0 & Sales \\
\hline & & & & $\begin{array}{l}\text { Palm kernel } \\
\text { meal }\end{array}$ & 1.11 & 0.25 & 0.29 & Sales \\
\hline \multirow{2}{*}{$\begin{array}{l}\text { Palm kernel } \\
\text { shells }\end{array}$} & 0.39 & 0 & 0.16 & & 0.09 & 0 & 0.04 & Sales \\
\hline & & & & & 0.30 & 0 & 0.12 & $\begin{array}{l}\text { CHP ash, } \\
\text { dumped }\end{array}$ \\
\hline \multirow{2}{*}{$\begin{array}{l}\text { Mesocarp } \\
\text { fibre }\end{array}$} & 1.51 & 0.65 & 2.60 & & 0.42 & 0.18 & 0.73 & Sales \\
\hline & & & & & 1.09 & 0.47 & 1.87 & $\begin{array}{l}\text { CHP ash } \\
\text { dumped }\end{array}$ \\
\hline POME & 1.00 & 0.25 & 2.85 & & & & & Discharged \\
\hline \multirow[t]{2}{*}{$\begin{array}{l}\text { Empty fruit } \\
\text { bunch }\end{array}$} & 1.43 & 0.24 & 3.58 & $\begin{array}{l}\text { EFB black } \\
\text { pellets }\end{array}$ & 0.24 & 0.03 & 0.14 & $\begin{array}{l}\text { Sold and } \\
\text { exported as } \\
\text { fuel }\end{array}$ \\
\hline & & & & $\begin{array}{l}\text { EFB } \\
\text { effluent }\end{array}$ & 1.19 & 0.21 & 3.44 & $\begin{array}{l}\text { For internal } \\
\text { use (energy } \\
\text { for } \\
\text { TORWASH }^{\circledR} \text { ) }\end{array}$ \\
\hline
\end{tabular}

The difference with the base case:

- $\quad 1.19 \mathrm{~kg} \mathrm{~N}, 0.21 \mathrm{~kg} \mathrm{P}$ and $3.44 \mathrm{~kg} \mathrm{~K}$ per hour recycled via EFB TORWASH ${ }^{\circledR}$ to the plantation.

- Same amount lower input of (synthetic) nutrients 


\subsection{Alternative 4: EFB washing and feeding in the existing CHP}

Table 44 Mass flows.

\begin{tabular}{|c|c|c|}
\hline \multicolumn{3}{|l|}{ Primary products } \\
\hline Material type & Mass flow (ton DM/h) & Destination \\
\hline Fresh Fruit Bunch & 1.0 & Palm oil mill \\
\hline Fronds & 0.83 & Left in the field \\
\hline Trunks & 0.24 & Left in the field \\
\hline
\end{tabular}

\begin{tabular}{|c|c|c|c|c|}
\hline \multicolumn{5}{|c|}{ Products from FFB from the palm oil mill } \\
\hline Material type & $\begin{array}{l}\text { Mass flow (ton } \\
\mathrm{DM} / \mathrm{h} \text { ) }\end{array}$ & $\begin{array}{l}\text { Split up (material } \\
\text { type) }\end{array}$ & $\begin{array}{l}\text { Split up mass flow } \\
\text { (ton } \mathrm{DM} / \mathrm{h} \text { ) }\end{array}$ & Destination \\
\hline Crude palm oil & 0.34 & & & Sales \\
\hline \multirow[t]{2}{*}{ Palm kernel } & 0.083 & Palm kernel oil & 0.042 & Sales \\
\hline & & Palm kernel meal & 0.041 & Sales \\
\hline \multirow[t]{2}{*}{ Palm kernel shells } & 0.077 & & 0.032 & Sales \\
\hline & & & 0.046 & $\mathrm{CHP}$ \\
\hline Mesocarp fibre & 0.22 & & 0.22 & Sales \\
\hline \multirow[t]{2}{*}{ POME } & 0.050 & POME & 0.043 & Discharged \\
\hline & & methane & 0.00685 & Emission \\
\hline \multirow[t]{2}{*}{ Empty fruit bunch } & 0.24 & Wash water & 0.024 & Reused in the field \\
\hline & & Washed EFB & 0.216 & CHP \\
\hline
\end{tabular}

The difference with the base case:

- $\quad 15 \mathrm{~kg}$ palm kernel shells DM (per hour) shift from CHP use to sales

- 216 kg EFB DM per hour now recovered, washed and use in CHP 
Table 45 Energy flows.

\begin{tabular}{|c|c|c|}
\hline \multicolumn{3}{|l|}{ Primary products } \\
\hline Material type & Energy flow (GJ/h) & Destination \\
\hline Fresh Fruit Bunch & 28.54 & Palm oil mill \\
\hline Fronds & 13.8 & Left in the field \\
\hline Trunks & 4.97 & Left in the field \\
\hline
\end{tabular}

\begin{tabular}{|c|c|c|c|c|c|c|}
\hline \multicolumn{7}{|c|}{ Products from FFB from the palm oil mill } \\
\hline Material type & $\begin{array}{l}\text { Higher } \\
\text { heating } \\
\text { value } \\
\text { (GJ/ton } \\
\text { DM) }\end{array}$ & $\begin{array}{l}\text { Energy flow } \\
\text { (GJ/h) }\end{array}$ & $\begin{array}{l}\text { Split up } \\
\text { (material } \\
\text { type) }\end{array}$ & $\begin{array}{l}\text { Higher } \\
\text { heating } \\
\text { value } \\
\text { (GJ/ton } \\
\text { DM) }\end{array}$ & $\begin{array}{l}\text { Split up } \\
\text { energy flow } \\
\text { (GJ/h) }\end{array}$ & Destination \\
\hline Crude palm oil & 40 & 13.73 & & & & Sales \\
\hline \multirow[t]{2}{*}{ Palm kernel } & 29.8 & 2.48 & $\begin{array}{l}\text { Palm kernel } \\
\text { oil }\end{array}$ & 40 & 1.67 & Sales \\
\hline & & & $\begin{array}{l}\text { Palm kernel } \\
\text { meal }\end{array}$ & 21 & 0.86 & Sales \\
\hline \multirow{2}{*}{$\begin{array}{l}\text { Palm kernel } \\
\text { shells }\end{array}$} & 21 & 1.63 & & & 0.67 & Sales \\
\hline & & & & & 0.96 & $\mathrm{CHP}$ \\
\hline $\begin{array}{l}\text { Mesocarp } \\
\text { fibre }\end{array}$ & 21 & 4.54 & & & 4.54 & Sales \\
\hline \multirow[t]{2}{*}{ POME } & 21 & 1.05 & POME & 15.6 & 0.67 & Discharged \\
\hline & & & methane & 55.4 & 0.38 & Emission \\
\hline \multirow[t]{2}{*}{$\begin{array}{l}\text { Empty fruit } \\
\text { bunch }\end{array}$} & 21 & 5.01 & Wash water & 20.8 & 0.50 & $\begin{array}{l}\text { Reused in the } \\
\text { field }\end{array}$ \\
\hline & & & Washed EFB & 21.5 & 4.51 & CHP \\
\hline
\end{tabular}




\begin{tabular}{|l|l|}
\hline \multicolumn{2}{|l|}{ Products from the CHP } \\
\hline Product type & Energy flow (GJ/h) \\
\hline Electricity & 0.20 \\
\hline Heat that can be used by the mill & 3.12 \\
\hline Heat loss (chimney) & 2.15 \\
\hline
\end{tabular}

The difference with the base case:

- $\quad 0.30 \mathrm{GJ} / \mathrm{h}$ from palm kernel shells shift from CHP use to sales

- $4.54 \mathrm{GJ} / \mathrm{h}$ mesocarp fibres shift from CHP to sales

- EFB now washed and used as fuel in CHP (4.51 GJ/h)

- $0.05 \mathrm{GJ} / \mathrm{h}$ additional heat loss

Table 46 Nutrient flows.

\begin{tabular}{|c|c|c|c|c|}
\hline \multicolumn{5}{|l|}{ Fertilizer input } \\
\hline & $\mathrm{kg} \mathrm{N} / \mathrm{h}$ & $\mathrm{kg} \mathrm{P} / \mathrm{h}$ & $\mathrm{kg} \mathrm{K} / \mathrm{h}$ & \\
\hline Fertilizer & 9.03 & 5.48 & 6.28 & \\
\hline \multicolumn{5}{|c|}{ Primary products and fertilizer loss } \\
\hline & $\mathrm{kg} \mathrm{N} / \mathrm{h}$ & $\mathrm{kg} \mathrm{P} / \mathrm{h}$ & $\mathrm{kg} \mathrm{K} / \mathrm{h}$ & destination \\
\hline Fresh Fruit Bunch & 5.50 & 1.40 & 9.50 & Palm oil mill \\
\hline Fronds & 5.79 & 0.50 & 10.74 & $\begin{array}{l}\text { Left in the field, } \\
\text { nutrients recycled }\end{array}$ \\
\hline Trunks & 0.95 & 0.17 & 3.78 & $\begin{array}{l}\text { Left in the field, } \\
\text { nutrients recycled }\end{array}$ \\
\hline Fertilizer loss & 3.67 & 4.20 & 0 & Lost \\
\hline
\end{tabular}




\begin{tabular}{|c|c|c|c|c|c|c|c|c|}
\hline \multicolumn{9}{|c|}{ Products from FFB from the palm oil mill } \\
\hline $\begin{array}{l}\text { Material } \\
\text { type }\end{array}$ & $\begin{array}{l}\mathrm{kg} \\
\mathrm{N} / \mathrm{h}\end{array}$ & $\begin{array}{l}\mathrm{kg} \\
\mathrm{P} / \mathrm{h}\end{array}$ & $\mathrm{kg} \mathrm{K} / \mathrm{h}$ & $\begin{array}{l}\text { Split up } \\
\text { (material } \\
\text { type) }\end{array}$ & $\mathrm{kg} \mathrm{N} / \mathrm{h}$ & $\mathrm{kg} \mathrm{P} / \mathrm{h}$ & $\mathrm{kg} \mathrm{K} / \mathrm{h}$ & Destination \\
\hline $\begin{array}{l}\text { Crude palm } \\
\text { oil }\end{array}$ & 0 & 0 & 0 & & & & & Sales \\
\hline \multirow[t]{2}{*}{ Palm kernel } & 1.12 & 0.25 & 0.29 & $\begin{array}{l}\text { Palm kernel } \\
\text { oil }\end{array}$ & 0.01 & 0 & 0 & Sales \\
\hline & & & & $\begin{array}{l}\text { Palm kernel } \\
\text { meal }\end{array}$ & 1.11 & 0.25 & 0.29 & Sales \\
\hline \multirow[t]{2}{*}{$\begin{array}{l}\text { Palm kernel } \\
\text { shells }\end{array}$} & 0.39 & 0 & 0.16 & & 0.16 & 0 & 0.07 & Sales \\
\hline & & & & & 0.23 & 0 & 0.09 & $\begin{array}{l}\text { CHP ash, } \\
\text { dumped }\end{array}$ \\
\hline $\begin{array}{l}\text { Mesocarp } \\
\text { fibre }\end{array}$ & 1.51 & 0.65 & 2.60 & & & & & Sales \\
\hline POME & 1.00 & 0.25 & 2.85 & & & & & Discharged \\
\hline \multirow[t]{2}{*}{$\begin{array}{l}\text { Empty fruit } \\
\text { bunch }\end{array}$} & 1.43 & 0.24 & 3.58 & Wash water & 0.143 & 0.12 & 3.22 & $\begin{array}{l}\text { Reused in the } \\
\text { field }\end{array}$ \\
\hline & & & & $\begin{array}{l}\text { Washed } \\
\text { EFB }\end{array}$ & 1.29 & 0.12 & 3.36 & $\begin{array}{l}\text { CHP, dumped } \\
\text { as ash }\end{array}$ \\
\hline
\end{tabular}

The difference with the base case:

- $\quad 0.14 \mathrm{~kg} \mathrm{~N}, 0.12 \mathrm{~kg}$ P and $3.22 \mathrm{~kg} \mathrm{~K}$ per hour recycled via EFB washing to the plantation.

- Same amount lower input of (synthetic) nutrients 


\subsection{Alternative 5: combination of using biogas from POME and washed EFB in the existing CHP}

Table 47 Mass flows.

\begin{tabular}{|c|c|c|}
\hline \multicolumn{3}{|c|}{ Primary products } \\
\hline \multirow{2}{*}{$\begin{array}{l}\text { Material type } \\
\text { Fresh Fruit Bunch }\end{array}$} & \multirow{2}{*}{$\begin{array}{l}\text { Mass flow (ton DM/h) } \\
1.0\end{array}$} & \multirow{2}{*}{$\begin{array}{l}\text { Destination } \\
\text { Palm oil mill }\end{array}$} \\
\hline & & \\
\hline Fronds & 0.83 & Left in the field \\
\hline Trunks & 0.24 & Left in the field \\
\hline
\end{tabular}

\begin{tabular}{|c|c|c|c|c|}
\hline Material type & $\begin{array}{l}\text { Mass flow } \\
\text { (ton } \mathrm{DM} / \mathrm{h} \text { ) }\end{array}$ & $\begin{array}{l}\text { Split up } \\
\text { (material } \\
\text { type) }\end{array}$ & $\begin{array}{l}\text { Split up mass } \\
\text { flow (ton } \\
\text { DM/h) }\end{array}$ & Destination \\
\hline Crude palm oil & 0.34 & & & Sales \\
\hline \multirow[t]{2}{*}{ Palm kernel } & 0.083 & $\begin{array}{l}\text { Palm kernel } \\
\text { oil }\end{array}$ & 0.042 & Sales \\
\hline & & $\begin{array}{l}\text { Palm kernel } \\
\text { meal }\end{array}$ & 0.041 & Sales \\
\hline \multirow[t]{2}{*}{$\begin{array}{l}\text { Palm kernel } \\
\text { shells }\end{array}$} & 0.077 & & 0.051 & Sales \\
\hline & & & 0.027 & $\mathrm{CHP}$ \\
\hline $\begin{array}{l}\text { Mesocarp } \\
\text { fibre }\end{array}$ & 0.22 & & 0.22 & Sales \\
\hline \multirow[t]{2}{*}{ POME } & 0.050 & POME & 0.043 & $\begin{array}{l}\text { Irrigation of } \\
\text { field }\end{array}$ \\
\hline & & methane & 0.00670 & CHP \\
\hline \multirow[t]{2}{*}{$\begin{array}{l}\text { Empty fruit } \\
\text { bunch }\end{array}$} & 0.24 & Wash water & 0.024 & $\begin{array}{l}\text { Reused in the } \\
\text { field }\end{array}$ \\
\hline & & Washed EFB & 0.216 & CHP \\
\hline
\end{tabular}

The difference with the base case:

- $\quad 34 \mathrm{~kg}$ palm kernel shells DM (per hour) shift from CHP use to sales

- $220 \mathrm{~kg}$ mesocarp fibre DM (per hour) shift from CHP use to sales

- EFB now utilized, washed and used in CHP (216 kg DM/h). 
Table 48 Energy flows.

\begin{tabular}{|c|c|c|}
\hline \multicolumn{3}{|l|}{ Primary products } \\
\hline Material type & Energy flow (GJ/h) & Destination \\
\hline Fresh Fruit Bunch & 28.54 & Palm oil mill \\
\hline Fronds & 13.8 & Left in the field \\
\hline Trunks & 4.97 & Left in the field \\
\hline
\end{tabular}

\begin{tabular}{|c|c|c|c|c|c|c|}
\hline \multicolumn{7}{|c|}{ Products from FFB from the palm oil mill } \\
\hline Material type & $\begin{array}{l}\text { Higher } \\
\text { heating } \\
\text { value } \\
\text { (GJ/ton } \\
\text { DM) }\end{array}$ & $\begin{array}{l}\text { Energy flow } \\
(\mathrm{GJ} / \mathrm{h})\end{array}$ & $\begin{array}{l}\text { Split up } \\
\text { (material } \\
\text { type) }\end{array}$ & $\begin{array}{l}\text { Higher } \\
\text { heating } \\
\text { value } \\
\text { (GJ/ton } \\
\text { DM) }\end{array}$ & $\begin{array}{l}\text { Split up } \\
\text { energy flow } \\
\text { (GJ/h) }\end{array}$ & Destination \\
\hline Crude palm oil & 40 & 13.73 & & & & Sales \\
\hline \multirow[t]{2}{*}{ Palm kernel } & 29.8 & 2.48 & $\begin{array}{l}\text { Palm kernel } \\
\text { oil }\end{array}$ & 40 & 1.67 & Sales \\
\hline & & & $\begin{array}{l}\text { Palm kernel } \\
\text { meal }\end{array}$ & 21 & 0.86 & Sales \\
\hline \multirow[t]{2}{*}{$\begin{array}{l}\text { Palm kernel } \\
\text { shells }\end{array}$} & 21 & 1.63 & & & 1.06 & Sales \\
\hline & & & & & 0.57 & $\mathrm{CHP}$ \\
\hline $\begin{array}{l}\text { Mesocarp } \\
\text { fibre }\end{array}$ & 21 & 4.54 & & & 4.54 & Sales \\
\hline \multirow[t]{2}{*}{ POME } & 21 & 1.05 & POME & 15.6 & 0.68 & $\begin{array}{l}\text { Irrigation of } \\
\text { field }\end{array}$ \\
\hline & & & methane & 55.4 & 0.37 & $\mathrm{CHP}$ \\
\hline \multirow[t]{2}{*}{$\begin{array}{l}\text { Empty fruit } \\
\text { bunch }\end{array}$} & 21 & 5.01 & Wash water & 20.8 & 0.024 & $\begin{array}{l}\text { Reused in the } \\
\text { field }\end{array}$ \\
\hline & & & Washed EFB & 21.5 & 4.51 & CHP \\
\hline
\end{tabular}

\begin{tabular}{|l|l|}
\hline \multicolumn{2}{|l|}{ Products from the CHP } \\
\hline Product type & Energy flow (GJ/h) \\
\hline Electricity & 0.20 \\
\hline Heat that can be used by the mill & 3.12 \\
\hline Heat loss (chimney) & 2.12 \\
\hline
\end{tabular}

The difference with the base case: 
- $\quad 0.69 \mathrm{GJ} / \mathrm{h}$ from palm kernel shells shift from CHP use to sales

- $\quad 4.54 \mathrm{GJ} / \mathrm{h}$ mesocarp fibres shift from CHP to sales

- $\quad$ EFB now washed and used as fuel in CHP $(4.51 \mathrm{GJ} / \mathrm{h})$

- $\quad 0.37 \mathrm{GJ} / \mathrm{h}$ now recovered as methane from POME and used in the CHP

- $0.02 \mathrm{GJ} / \mathrm{h}$ additional heat loss in CHP

Table 49 Nutrient flows.

\begin{tabular}{|c|c|c|c|c|}
\hline \multicolumn{5}{|l|}{ Fertilizer input } \\
\hline & $\mathrm{kg} \mathrm{N} / \mathrm{h}$ & $\mathrm{kg} \mathrm{P} / \mathrm{h}$ & $\mathrm{kg} \mathrm{K} / \mathrm{h}$ & \\
\hline Fertilizer & 8.03 & 5.23 & 3.43 & \\
\hline \multicolumn{5}{|c|}{ Primary products and fertilizer loss } \\
\hline & $\mathrm{kg} \mathrm{N} / \mathrm{h}$ & $\mathrm{kg} \mathrm{P} / \mathrm{h}$ & $\mathrm{kg} \mathrm{K} / \mathrm{h}$ & destination \\
\hline Fresh Fruit Bunch & 5.50 & 1.40 & 9.50 & Palm oil mill \\
\hline Fronds & 5.79 & 0.50 & 10.74 & $\begin{array}{l}\text { Left in the field, } \\
\text { nutrients recycled }\end{array}$ \\
\hline Trunks & 0.95 & 0.17 & 3.78 & $\begin{array}{l}\text { Left in the field, } \\
\text { nutrients recycled }\end{array}$ \\
\hline Fertilizer loss & 3.67 & 4.20 & 0 & Lost \\
\hline
\end{tabular}




\begin{tabular}{|c|c|c|c|c|c|c|c|c|}
\hline \multicolumn{9}{|c|}{ Products from FFB from the palm oil mill } \\
\hline $\begin{array}{l}\text { Material } \\
\text { type }\end{array}$ & $\begin{array}{l}\mathrm{kg} \\
\mathrm{N} / \mathrm{h}\end{array}$ & $\begin{array}{l}\mathrm{kg} \\
\mathrm{P} / \mathrm{h}\end{array}$ & $\mathrm{kg} \mathrm{K} / \mathrm{h}$ & $\begin{array}{l}\text { Split up } \\
\text { (material } \\
\text { type) }\end{array}$ & $\mathrm{kg} \mathrm{N} / \mathrm{h}$ & $\mathrm{kg} \mathrm{P} / \mathrm{h}$ & $\mathrm{kg} \mathrm{K} / \mathrm{h}$ & Destination \\
\hline $\begin{array}{l}\text { Crude palm } \\
\text { oil }\end{array}$ & 0 & 0 & 0 & & & & & Sales \\
\hline \multirow[t]{2}{*}{ Palm kernel } & 1.12 & 0.25 & 0.29 & $\begin{array}{l}\text { Palm kernel } \\
\text { oil }\end{array}$ & 0.01 & 0 & 0 & Sales \\
\hline & & & & $\begin{array}{l}\text { Palm kernel } \\
\text { meal }\end{array}$ & 1.11 & 0.25 & 0.29 & Sales \\
\hline \multirow{2}{*}{$\begin{array}{l}\text { Palm kernel } \\
\text { shells }\end{array}$} & 0.39 & 0 & 0.16 & & 0.25 & 0 & 0.10 & Sales \\
\hline & & & & & 0.14 & 0 & 0.06 & $\begin{array}{l}\text { CHP ash, } \\
\text { dumped }\end{array}$ \\
\hline $\begin{array}{l}\text { Mesocarp } \\
\text { fibre }\end{array}$ & 1.51 & 0.65 & 2.60 & & & & & Sales \\
\hline POME & 1.00 & 0.25 & 2.85 & & & & & Discharged \\
\hline \multirow[t]{2}{*}{$\begin{array}{l}\text { Empty fruit } \\
\text { bunch }\end{array}$} & 1.43 & 0.24 & 3.58 & Wash water & 0.143 & 0.12 & 3.22 & $\begin{array}{l}\text { Reused in the } \\
\text { field }\end{array}$ \\
\hline & & & & $\begin{array}{l}\text { Washed } \\
\text { EFB }\end{array}$ & 1.29 & 0.12 & 3.36 & $\begin{array}{l}\text { CHP, dumped } \\
\text { as ash }\end{array}$ \\
\hline
\end{tabular}

The difference with the base case:

- $1 \mathrm{~kg} \mathrm{~N}, 0.15 \mathrm{~kg} P$ and $2.85 \mathrm{~kg} \mathrm{~K}$ per hour recycled via POME to the plantation.

- $0.14 \mathrm{~kg} \mathrm{~N}, 0.12 \mathrm{~kg} P$ and $3.22 \mathrm{~kg} \mathrm{~K}$ per hour recycled via EFB washing to the plantation.

- $1.14 \mathrm{~kg} \mathrm{~N}, 0.27 \mathrm{~kg} P$ and $6.07 \mathrm{~kg} \mathrm{~K}$ per hour lower input of (synthetic) nutrients . 



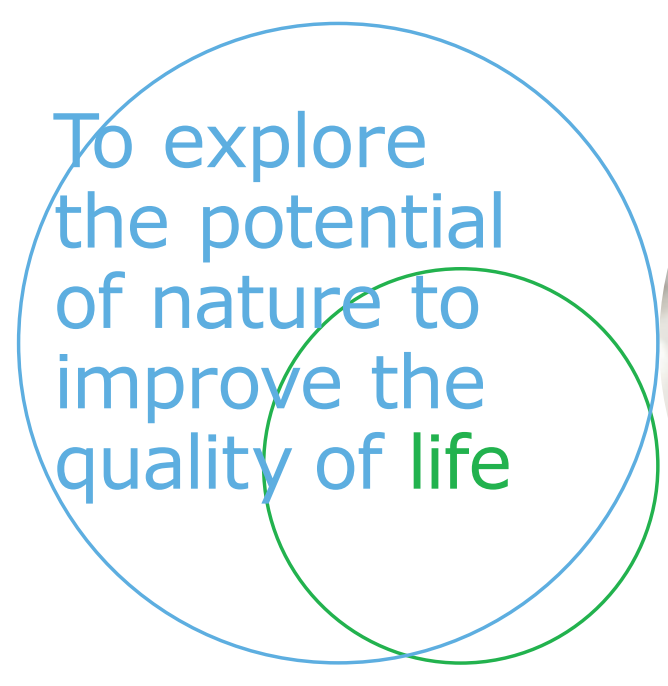

Wageningen Food \& Biobased Research Bornse Weilanden 9

6708 WG Wageningen

The Netherlands

www.wur.eu/wfbr

E info.wfbr@wur.nl

Report 1989

ISBN 978-94-6395-181-4

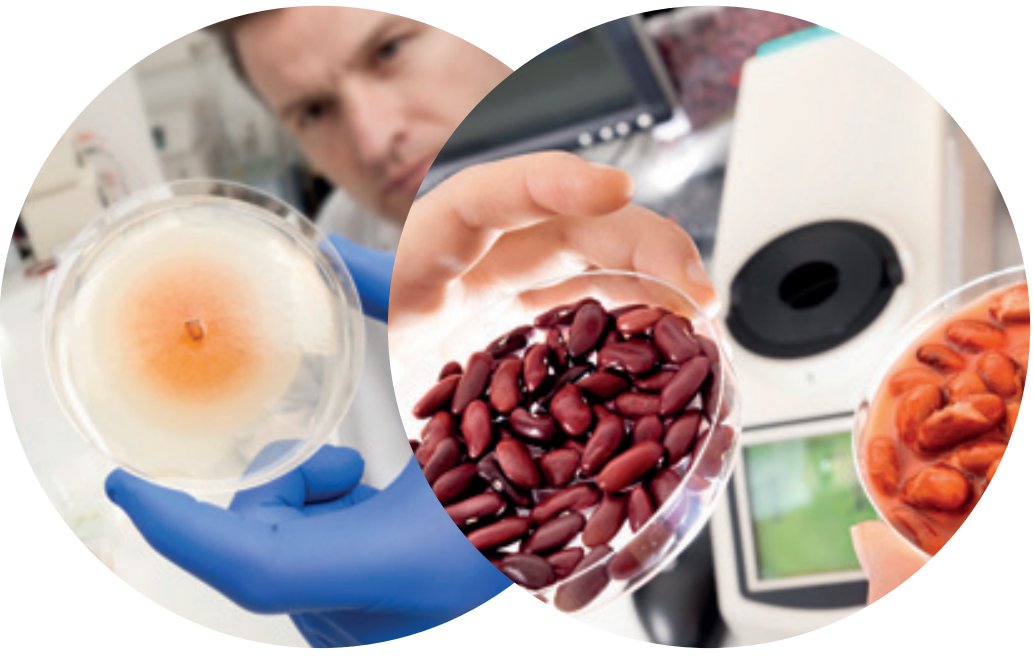

The mission of Wageningen University and Research is "To explore the potential of nature to improve the quality of life". Under the banner Wageningen University \& Research, Wageningen University and the specialised research institutes of the Wageningen Research Foundation have joined forces in contributing to finding solutions to important questions in the domain of healthy food and living environment. With its roughly 30 branches, 5,000 employees and 10,000 students, Wageningen University \& Research is one of the leading organisations in its domain. The unique Wageningen approach lies in its integrated approach to issues and the collaboration between different disciplines. 